\title{
STRUCTURES OF LIMITED DUCTILITY
}

\section{This report is the result of deliberations of the Society's Study Group for Strutures of Limited Ductility.}

\section{INTRODUCTION \\ 1.1 Objectives}

In late 1985 the Management Committee of the New Zealand National Society for Earthquake Engineering set up a Study Group to consider structures of limited ductility.

The object of the Study Group was to compile information so that engineers are better able to:

Economically design structures that fall between fully ductile and elastically responding, that is, structures with strengths greater than required by code seismic loading for fully ductile behaviour, or less important structures which do not warrant detailing for full ductility.

Evaluate existing structures that do not possess the ductility detailing required by modern codes nor possess adequate strength to respond elastically to 'design' earthquakes.

The Study Group was requested to produce a report within one year covering the current state of procedures, possible future developments and needed research.

To achieve this task the Study Group met on three occasions, namely 4 February 1986,27 May 1986 and 20 August 1986, and considered:

(1) The current endeavours by various groups to quantify descriptions of, and design procedures for, various levels of structural ductility. Groups in New Zealand which have studied or are currently studying the problem include study groups of the Society and committees of the Standards Association of New Zealand on general structural design and design loadings concrete structures, masonry structures, timber structures, and structural steel structures.

The technical literature to assess available analytical and experimental data on the response and performance of structures of limited ductility of various types of materials. This was to permit evaluation of whether such literature is a fruitful area to further research with a view to establishing rules for limited ductility design and evaluation. Also it would lead to suggestions of areas where future research is needed for the development of those rules.

This report is the outcome of those considerations.

\subsection{Personnel}

The members of the Study Group were:

Prof. R. Park (Convenor), University of Canterbury.

Mr. R.B. Shephard, (Co-convenor), Ministry of Works and Development.

Mr. A.L. Andrews, Consulting Engineer.

Mr. D.R. Brunsdon, Consulting Engineer.

Dr. A.H. Buchanan, Consulting Engineer (Deputy: Dr. J.A. Dean, University of Canterbury)

Dr. A.J. Carr, University of Canterbury.

Mr. H.E. Chapman, Ministry of Works and Development.

Dr. M.J.N. Priestley, University of Canterbury.

Mr. L.M. Robinson, Consulting Engineer.

Mr. K.F.C. Spring, Consulting Engineer (Deputy: Mr. G.C. Clifton, Heavy Engineering Research Association).

Miss M.T. Soesianawati, University of Canterbury

\subsection{Papers of the Report}

The results of the deliberations of the Study Group are set out in the following sections:

1. Introduction

2. Design of Building Structures of Limited Ductility

2.1 Philosophy of Design Approach R. Park and A.L. Andrews.

2.2 Reinforced Concrete - R. Park and L.M. Robinson.

2.3 Masonry - M.J.N. Priestley.

2.4 Structural Steel - K.F.C. Spring

2.5 Timber - A.H. Buchanan.

3. Design of Bridge Substructures of Limited Ductility - H.E. Chapman

4. Evaluation of Existing Structures - D.R. Brunsdon and R.B. Shephard

5. References

6. Notation 
2. DESIGN OF BUILDING STRUCTURES OF LIMITED DUCTILITY

\subsection{PHILOSOPHY OF DESIGN APPROACH}

by $R$. Park, University of Canterbury, Christchurch, and A.L. Andrews, Consulting Engineer, Wellington.

\subsubsection{Introduction}

It is well known that when a structure responds elastically to ground motions during a severe earthquake, the maximum response acceleration may be several times the maximum ground acceleration and depends on the stiffness of the structure and the magnitude of the damping. Generally it is uneconomical to design a structure to respond in the elastic range to the greatest likely earthquake induced inertia forces. As a result, the design seismic horizontal forces recommended by codes are generally much less than the elastic response inertia forces induced by a major earthquake.

Experience has shown that structures designed to the level of seismic horizontal forces recommended by codes can survive major earthquake shaking. This apparent anomaly has been attributed mainly to the ability of well designed structures to undergo significant deformations in the inelastic range without collapse, possibly helped by reduced response due to decrease in stiffness, to soil-structure interaction and to other factors. Thus structures that that are designed to yield are known to respond to intense earthquake motions by developing peaks of horizontal acceleration that are smaller than the peaks developed by equivalent elastic structures. Designers have been taking advantage of the stress limiting ability that this behaviour makes available for more than 20 years.

It is evident that use of the level of static seismic design loads recommended by codes implies that the critical regions of those members should have sufficient ductility to enable the structure to survive without collapse. Ductility means the ability of the member to undergo several reversals of displacement beyond the point of first yield while maintaining a substantial portion of its initial maximum load carrying capacity.

In setting the levels of design static seismic loading, codes have to consider the associated post-elastic deformations of the structure designed to that strength, in order to ensure that the ductility demand can be met by the members. Non-linear dynamic analyses of code designed multi-storey structures responding to typical najor earthquake ground motions have given an indication of the order of post-elastic deformations, and hence the ductility required. However the number of variables involved in such analyses is great and no more than qualitative statements concerning ductility demand can be made. For example, the type of ground motion has a considerable influence. Nevertheless some general conclusions can be drawn. philosophy of the design approach for ductile structures will be discussed, as well as that for structures of limited ductility. in order that the two approaches may be compared.

\subsubsection{Displacement Ductility Factor}

A measure of the ductility required of a structure is the displacement ductility factor $\mu$ defined as

$$
\mu=\Delta_{u} / \Delta_{y}
$$

where $\Delta_{1}=$ maximum horizontal displacement of the structure during severe earthquake shaking, generally measured either at the top of the structure or at the point of action of the resultant horizontal seismic load.

$\Delta_{y}=$ horizontal displacement at that point of the structure at first yield.

In the case of an elasto-plastic load-displacement response, shown in Fig. I the definition of the first yield displacement is obvious. For structures with a curved load-displacement relation, the definition for first yield displacement illustrated in Fig. 2 has commonly been adopted in New Zealand. That is, the displacement at first yield is taken as that of an elasto-plastic system with the same initial stiffness and ultimate load as for the system with the curved response. Such a response may occur, for example, due to plastic hinges not forming simultaneously in the members of the structure when the imposed load is increased. For structures from materials such as reinforced concrete and timber the non-linearity in the loaddisplacement response may occur at a relatively low imposed load. For example, in the case of reinforced concrete, cracking may occur in the service load range resulting in a reduction in the flexural stiffness. Also, yielding of all longitudinal reinforcement will not occur at the same imposed load, since bars near the extreme fibres of the section will reach yield before bars closer to the neutral axis. For such a non-linear system the definition for first yield displacement illustrated in Fig. 3 has been adopted at the University of Canterbury when testing reinforced concrete elements and subassemblages of structures. The theoretical ultimate load $\mathrm{H}_{u}$ is normally that calculated using the stress-strain properties of the steel and confined concrete. It is considered that at $0.75 \mathrm{H}_{\mathrm{u}}$ the cracking of the member has fully developed and the straight line passing through that point and the origin gives a good indication of the flexural stiffness of the cracked member in the elastic range.

It is evident that the first yield displacement must be defined carefuliy since otherwise the ductility factor is an imprecise quantity. This applies both in the assessment of available ductility from the results of laboratory tests and theoretical analysis, and in the determination of ductility demand from dynamic analyses incorporating hysteresis loops of general 


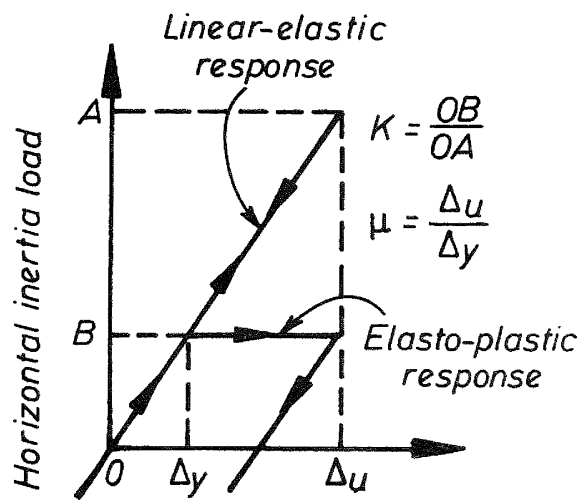

Horizontal displacement

(a) Equal Maximum Displacement Response $\mu=\frac{l}{K}$

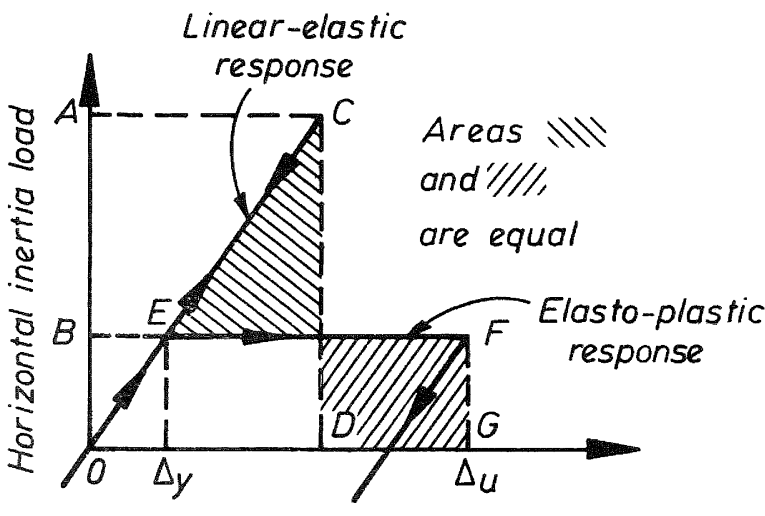

Horizontal displacement

(b) Equal Maximum Energy Response $\mu=\frac{1}{2}\left(1+\frac{1}{K^{2}}\right)$

Fig. 1 - Two Commonly Assumed Responses of Elastic and Elasto-Plastic Systems Responding to Severe Horizontal Earthquake Ground Motions

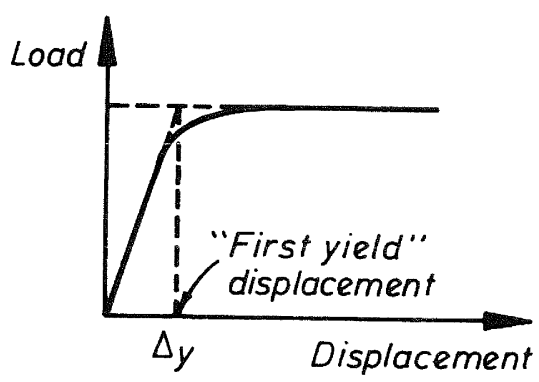

Fig. 2 - Definition of First Yield Displacement When the Load-Displacement Relation is Curved

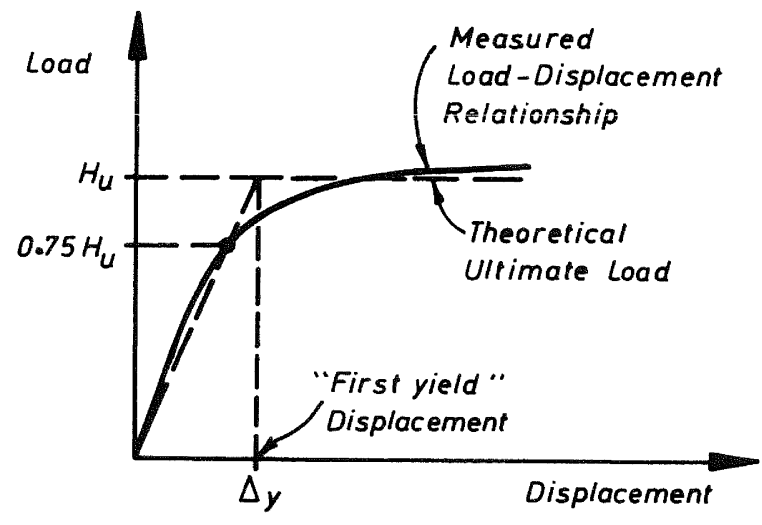

Fig. 3 - Possible Definition of First Yield Displacement When the Non-Linearity in the Load-Deflection Relation Commences at a Relatively Low Load, Such as Due to Cracking of Reinforced Concrete 
shape. It should be noted that the important parameters are in fact the available and required ultimate or maximum displacements, but it has been customary to divide these quantities by the first yield displacement to represent the parameters as a nondimensional quantity, namely the displacement ductility factor. It may be that the storey drift, that is the ratio of the horizontal displacement occurring between successive storeys divided by the storey height, would be a better non-dimensional parameter to use to quantify the available and required displacement capacity, thus avoiding the need for consideration of the first yield displacement.

\subsubsection{Relationships Between Design Seismic Loads and Displacement Ductility Factor}

The design static seismic loads specified by codes have normally been found from a suitable elastic response spectrum, based on the seismicity of the area, soil condition and importance of the structure, with modifjcation to take into account the ductility of the structure.

Generally an "equal maximum displacement" concept has been used to determine the design seismic forces from the elastic response spectrum. The equal maximum displacement concept, illustrated in Fig. la, is based on the observation that a number of dynamic analyses of structural systems responding to recorded earthquake ground motions have indicated that the maximum horizontal displacements reached by a structure that is not strong enough to resist the full elastic response inertia force, and yields with elasto-plastic forcedisplacement characteristics, is approximately the same as that of a structure which is strong enough to respond in the elastic range.

The seismic design loads of the current New Zealand loadings code [1] are based on the equal maximum displacement concept. The ratio of the design seismic force to the elastic response inertia force is the reduction factor $K$. In Fig. la, $\mathrm{K}=\mathrm{OB} / \mathrm{OA}$. Typically for ductile structures the current New Zealand loadings code assumes an available displacement ductility factor of about $\mu=4$ or higher, and the design seismic loads can therefore be regarded as being approximately $1 / \mu$ of the elastic response inertia loads. However the actual design spectrum used for seismic loading does not follow the exact shape of an elastic response spectrum but is of tri-linear shape.

It has been known for some years that the use of the equal maximum displacement concept may be incautious. For example, for structures with short fundamental periods of vibration the maximum displacements reached can be much greater than implied by the equal maximum displacement concept. Many dynamic analyses have indicated that for structures with small periods of vibration a better approximation relating the displacement ductility factor $\mu$ and the reduction factor $K$ is given by the "equal maximum energy" concept illustrated in Fig. Ib in which the area OCD is equal to the area OEFG.
The greater deflection response of the short period structure responding elastoplastically compared with the elastically responding structure, results from the lengthening of the period into a periodrange of higher response as a result of inelastic behaviour. However, this may be of no consequence since most spectra for design seismic forces have a horizontal limb in the small period range rather than following the theoretical reduction in seismic force with reducing period in the small period range. Also, it is common for very short period structures to radiate much more of their elastic energy into the ground than long period structures do, so that the effective damping ratio might be much higher than the structure elastic hysteretic damping that was used to define the resonse spectrum. It should also be noted that when the period of the structure approaches zero $(T=0)$ the structural response acceleration will equal the peak ground acceleration regardless of the ductility factor. Therefore the reduction factor should be $K=1.0$ at $T=0$ regardless of the ductility factor.

Other major variables affecting the displacement response of structures to major earthquakes are the characteristics of the ground motions of the earthquake. The elastic response spectrum of the current New Zealand loadings code for buildings [1] is based mainly on the EI Centro May 1940 earthquake record, but with account taken of some other United States earthquake records. Different earthquake records may result in greater displacement responses.

The current New Zealand loadings code for buildings is being rewritten [2] to include more recent knowledge on ductility demand and seismic loading spectra.

It is evident that the actual displacement ductility demand on a structure can be different from the code assumed values. Therefore it is important that the design provisions in the material codes for ensuring available ductility should be conservative and thus allow structures to reach somewhat greater ductility levels than required by the loadings code.

For bridges, the inertia forces from an earthquake only impose significant stresses on the supporting substructure of columns, piers, abutments and foundations. Building structures tend to have more complex structural systems and significant stresses may be imposed on the whole structural system. Because of this difference in the response of building and bridge structures, these structural types will be treated separately in this report. Building structures are treated further in this section 2 and bridge substructures are treated in section 3.

\subsubsection{Mechanisms of Inelastic Deformation of Building structures}

The exact characteristics of the earthquake ground motions that may occur at a given site cannot be predicted with certainty and it is difficult to evaluate all 
aspects of the complete behaviour of a complex structure when subjected to very large seismic disturbances. Nevertheless it is possible to impart to the structure features that will ensure the most desirable behaviour. In terms of damage, strength and ductility, this means ensuring a desirable sequence in reaching the strengths of the various modes of resistance of the structure. It implies a desired hierachy in the failure modes of the structure. The rational approach for achieving this aim in design for earthquake resistance is to choose the most suitable mechanism of inelastic deformation for the structure, and to ensure by appropriate design procedures that yielding will occur only in the chosen manner during a severe earthquake and that the available ductility is adequate.

For moment resisting frames and structural walls of reinforced concrete and masonry buildings the best means of achieving ductile inelastic deformation is by flexural yielding at selected plastic hinge positions, since with proper design the plastic hinges can be adequately ductile It is evident that the sequence of plastic hinge development in moment resisting frames and structural walls, responding to an acceleration pulse of a severe earthquake, will influence the ductility demand at the plastic hinges. Non-linear dynamic analyses have indicated that ductility demand concentrates in the weak parts of structures and that the curvature ductility demand there may be several times greater than for well proportioned structures. That is, in order to reduce ductility demand, it is important to prevent a non-uniform distribution of yielding and to ensure that the inelastic deformations are reasonably uniformly distributed throughout the structure. This can also be illustrated by examination of the possible mechanisms of inelastic deformation. Fig. 4 shows moment resisting frames and shear walls which can be used for seismic resistance. Some possible mechanisms which could form due to flexural yielding and formation of plastic hinges are also shown in the figure. If yielding commences in the columns of a frame before the beams, a column sidesway mechanism can form. In the worst case the plastic hinges may form in the columns of only one storey since the columns of the other storeys are stronger. Such a mechanism can make very large curvature ductility demands on the plastic hinges of the critical storey [3], particularly for tall buildings. On the other hand if yielding commences in the beams before in the columns a beam sidesway mechanism, as illustrated in the figure, will develop which makes more moderate demands on the curvature ductility required at the plastic hinges in the beams and at the column bases [3]. Therefore a beam sidesway mechanism is the preferred mode of inelastic deformation, since the required ductility can be more easily provided. Hence for ductile frames a strong columnweak beam approach is advocated to ensure beam hinging. For ductile frames of one to three storeys, and in the top storey of multi-storey frames, a column sidesway mechanism can be tolerated since the curvature ductility demand at the plastic hinges in the columns in such cases is not large and can be provided by proper detailing. In the actual dynamic situation higher modes of vibration influence the moment pattern and it has been found the plastic hinges in the beams moves up the frame in waves involving a few storeys at a time.

For cantilever structural walls the mechanism of inelastic deformation involves a plastic hinge at the base and the curvature ductility demand for a given displacement ductility factor depends very much on the plastic hinge length as a proportion of the wall height. For coupled structural walls the mechanism in Fig. 4 can occur [3] and ideally the beams should yield before the wall bases.

The static collapse mechanisms of Fig. 4 are idealised in that they involve behaviour under code type static loading. The actual dynamic situation is different, due mainly to the effects of higher modes of vibration, but nevertheless considerations such as in Fig. 4 give the designer a reasonable feel for the situation.

A prerequisite in the design of ductile plastic hinges is that flexural yielding should control the strength and inelastic deformations which occur. Hence the modes of brittle failure should be prevented. Fig. 5 shows possible modes of deformation in the inelastic range for a reinforced concrete cantilever structural wall. Possible deformation modes for the plastic hinge region at the end of a reinforced concrete beam in a moment resisting frame are similar to those for the wall in Fig. 4. For ductile behaviour yielding of the flexural reinforcement in the plastic hinge zone in the end region of the member should occur, as illustrated in Fig. $5 \mathrm{~b}$. The failure modes to be prevented in cantilever walls, or in beams or columns designed for ductility, are those due to diagonal tension (shown in Fig. $5 \mathrm{c}$ ) or diagonal compression caused by shear, instability of thin walled sections or of the principal compression reinforcement, sliding shear along construction joints (shown in Fig. 5d), and shear or bond failure along lapped splices or anchorages. Attempts must be made to control effects, particularly those due to shear, which lead to both premature stiffness and strength degradation and consequently to reduced ability for energy dissipation [4]. However it should be noted that the less ductile mechanisms for walls (Figs. $5 \mathrm{c}$ and d) may be adequate for walls designed for limited ductility [5].

The mechanisms of inelastic deformation of structural steel may be either by flexure, shear, tension or compression. For moment resisting frames of structural steel the inelastic deformation is designed to occur by flexural yielding. For eccentrically braced frames of structural steel the inelastic deformation is designed to occur by either plastic yielding in flexure in members (Fig. 6a) or by plastic yielding in shear in short lengths of members (Fig. $6 \mathrm{~b}, \mathrm{c}$ and d). For concentrically braced frames of structural steel the inelastic deformation is designed to occur by plastic yielding either in tension and compression, 


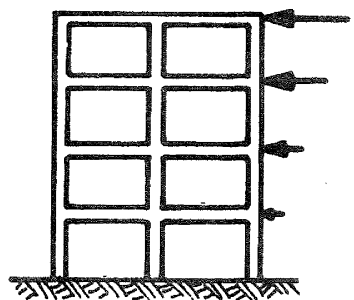

Frame

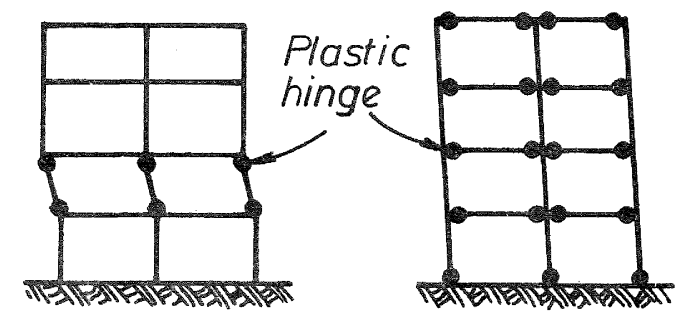

Column sidesway mechanism
Beam sidesway mechanism

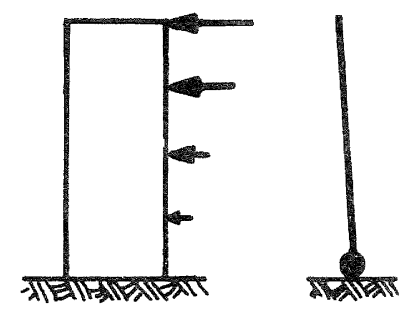

Cantilever structural walls and mechanism
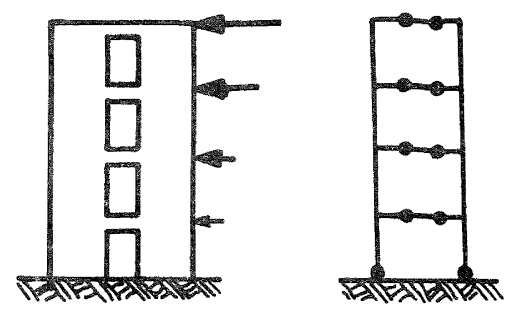

Coupled structural walls and mechanism

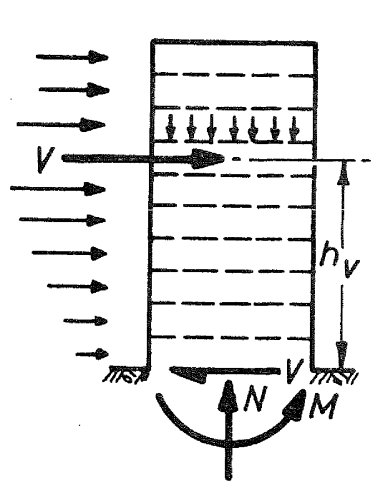

(a) Wall actions

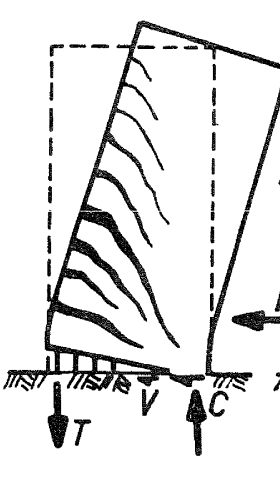

(b) Flexure (c)

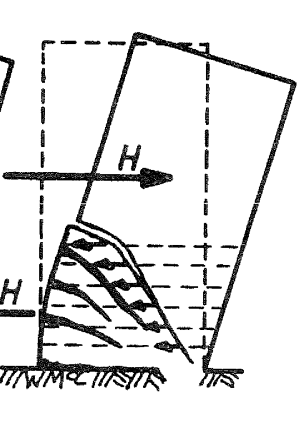

Diagonal
tension

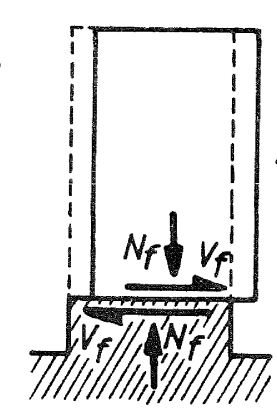
(d) Sliding shear

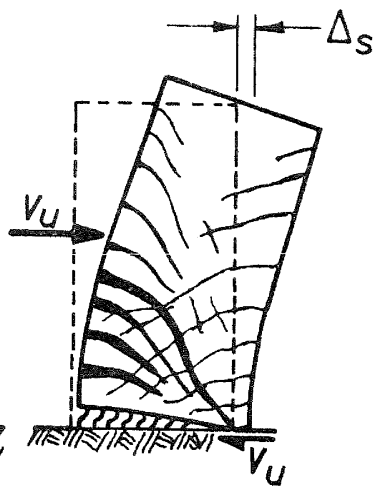

(e) Hinge sliding 


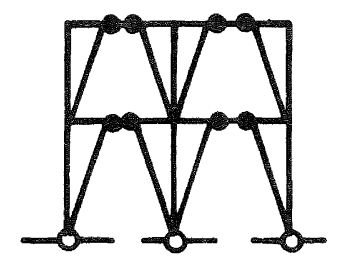

(a)

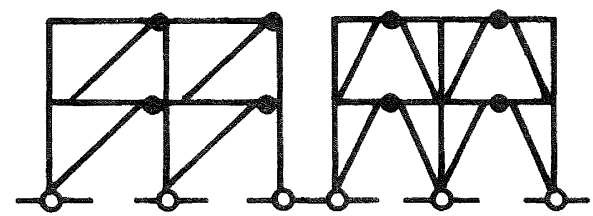

(b)

(c)

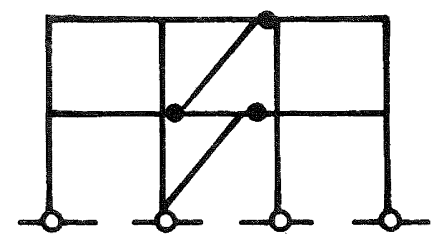

(d)

Eccentrically braced frames - Plastic yielding in flexure or shear

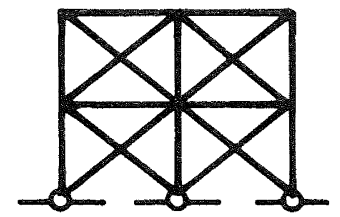

(e)

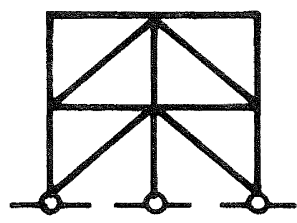

(f)

Concentrically braced frames-

Plastic yielding in tension and compression

Fig. 6 Mechanisms of Inelastic Deformation for Braced Frames

or in tension and controlled compression buckling (Fig. $6 e$ and $f$ ).

In most timber structural systems, the primary mechanisms of inelastic deformation are associated with either crushing of wood in compression or ductile yielding of steel fasteners. In many connections (nails for example) there is a combination of these two mechanisms. The structural systems most commonly used to resist lateral loads in timber structures are moment resisting frames with nailed connections, or timber framed shear walls sheathed with plywood. These systems are described in more detail in section 2.5 .

\subsubsection{Current New Zealand General Seismic Provisions for Ductile Building Structures}

(a)

\section{Introduction}

The current New Zealand general seismic design provisions for building structures are contained in a code for general structural design and design loadings [1]. This code was first published in 1976 and a second edition was published in 1984. The code sets out the following general seismic design principles for ductile structures, summarised in (b) to (e) below.

(b) Design Seismic Loads
When analysis is based on equivalent static forces representing the effect of the actual inertia forces induced by earthquake shaking, the equivalent static forces have the distribution prescribed by the code and the total horizontal seismic force in each direction under consideration is given by:

$$
\mathrm{V}=\mathrm{CRSMW}_{\mathrm{t}}
$$

where $C=$ basic seismic coefficient, varying between 0.15 and 0.05 depending on the seismic zone and the fundamental period of vibration of the structures

$\mathrm{R}=$ risk factor, varying between 1.0 and 2.0

$S$ = structural type factor, varying between 0.8 for ductile frames to 4 to 6 for elastically responding structures

$\mathrm{M}=$ structural material factor, either 0.8 for structural steel and reinforced concrete or 1.0 for prestressed concrete and structural masonry

$\mathrm{w}_{\mathrm{t}}=$ gravity load of structure considered to be present during an earthquake.

As mentioned earlier, these design seismic forces were obtained using the "equal maximum displacement" concept and on the basis of a smoothed compound spectrum obtained from the May $1940 \mathrm{E} 1$ Centro N-S earthquake 
record and some other United States records scaled to the $\mathrm{El}$ Centro $\mathrm{N}-\mathrm{S}$ record.

\section{(c) Adequate Ductility}

Structural systems intended to dissipate energy by ductile flexural yielding should have adequate ductility.

Adequate ductility may be considered to have been provided if all primary elements resisting seismic forces are detailed for ductility in accordance with the seismic provisions of the appropriate materials code.

An approximate criterion for adequate ductility, applicable to reasonably regular symmetrical frames without sudden changes in storey stiffness, given in the commentary of the code [1] is as follows: the building as a whole should be capable of deflecting laterally through at least eight load reversals so that the total horizontal deflection at the top of the main portion of the building under the design static seismic loading, calculated on the assumption of appropriate plastic hinges, is at least four times that at first yield, without the horizontal load carrying capacity of the building being reduced by more than 20\%. The horizontal deflection at the top of the building at first yield can be taken as that when the yield first occurs in any main structural element or that at the design static seismic load calculated on the assumption of elastic behaviour, whichever is the greater.

Note that of these two alternative methods for determining the deflection at first yield the method based on assuming elastic behaviour up to the design static seismic load is obviously the more realistic (see Figs. 2 and 3 ). This is because the designer generally will have incorporated some redistribution of bending moment from the elastic bending moment diagram when determining the design moments. In any case the actual distribution of flexural stiffness throughout the frame will not generally match the assumptions made by the designer. Hence some yielding of flexural members is possible before the design seismic load is reached.

\section{Capacity Design}

Building frames designed for ductile flexural yielding shall be the subject of "capacity design". In the capacity design of earthquake-resistant structures, energydissipating elements or mechanisms are chosen and suitably designed and detailed, and all other structural elements are then provided with sufficient reserve strength capacity to ensure that the chosen energydissipating mechanisms are maintained throughout the deformations that may occur.

\section{Concurrent Earthquake Loading} Effects

Columns or walls, including their joints and foundations, which are part of a two way force-resisting system, shall be designed for concurrent earthquake load effects resulting from the simultaneous yielding of all beams or diagonal braces framing into the columns or walls from all directions.

\subsubsection{Current New Zealand General Seismic Provisions for Structures of Limited Ductility}

The design of ductile structures can be a relatively complex procedure. For example, capacity design must be used. Also, for reinforced concrete frames ductile detailing of potential plastic hinge regions invariably results in the presence of large quantities of transverse reinforcement to confine the compressed concrete, to prevent premature buckling of longitudinal reinforcement, and to prevent shear failure, which often results in construction difficulties due to congestion of reinforcement.

Some structures, particularly frames or walls of small buildings of one to four storeys. and stocky bridge columns, can often be designed economically for higher seismic design loads. That is, the seismic design load used could be part way between the level for a ductile structure and an elastically responding structure. Then the structure may be designed for limited ductility.

Although a continuous trade off between strength and ductility could justifiably be made, design processes are more easily controlled by establishing discrete ductility levels for each of which the appropriate materials code specifies design and detailing rules. This is the New Zealand scheme, as developed, for example, in the New Zealand code for design of reinforced concrete [5]. "Fully" ductile structures are recognised as those that exhibit an available displacement ductility factor of 4 to 6 or more throughout several cycles without significant loss of strength. When the available displacement ductility factor is between 2 and 3 , the structure is deemed to have "limited" ductility. Less ductile materials and arrangements have not been credited with any load limiting capacity. These are the designated "elastically" responding structures.

For example. the New Zealand code for general structural design and design loadings for buildings [1] currently permits a Iimited ductility design approach for frames up to four or five storeys maximum height and for cantilever shear walls. The code [1] recommends structural type factors of $S=0.8$ for ductile frames, $S=1.0$ to 2.0 for ductile cantilever shear walls depending on the height/horizontal length ratio, and $S=2.0$ for frames and cantilever shear walls of limited ductility. Hence for frames of limited ductility the design seismic loading is 2.5 times that used for ductile frames, and for cantilever shear walls with height/horizontal length ratio of greater than 2 the design seismic loading can be 2.0 times that used for ductile cantilever shear walls. The advantage of this procedure is that a capacity design procedure is then unnecessary and a considerable relaxation in the detailing requirements for ductility is permitted. Hence the design is less complex. 


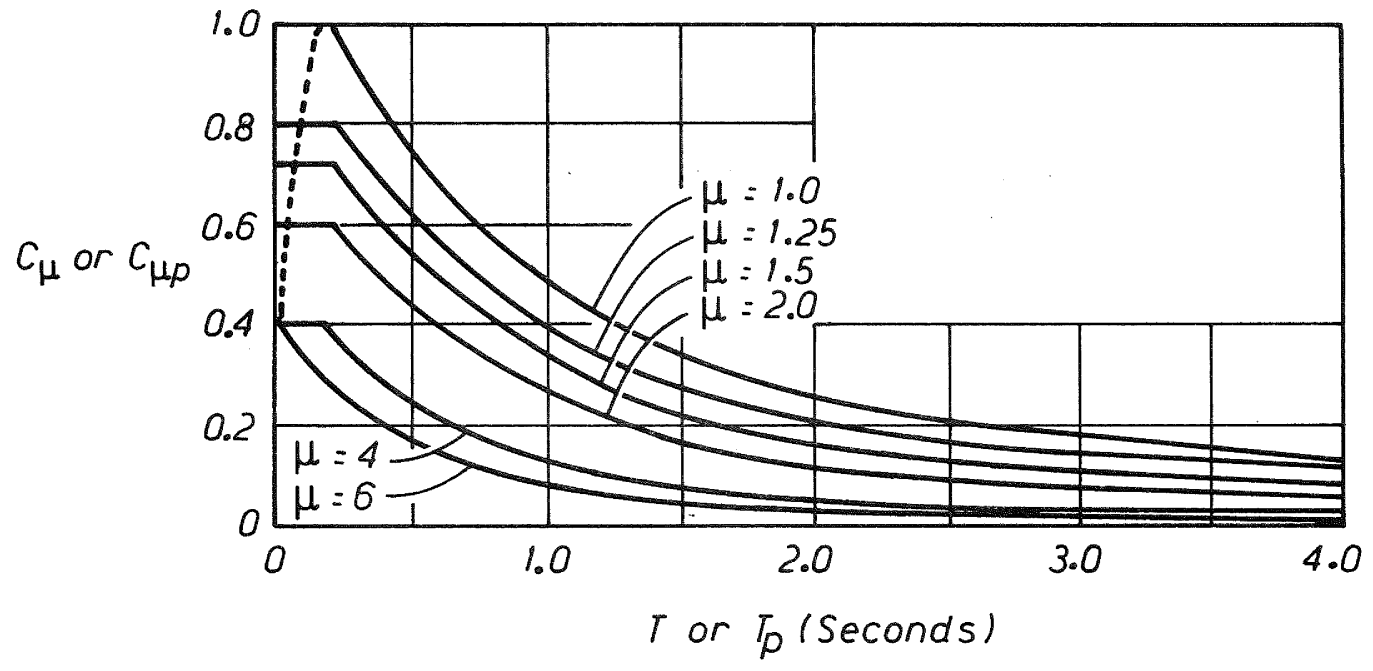

(a) NORMAL SOILS

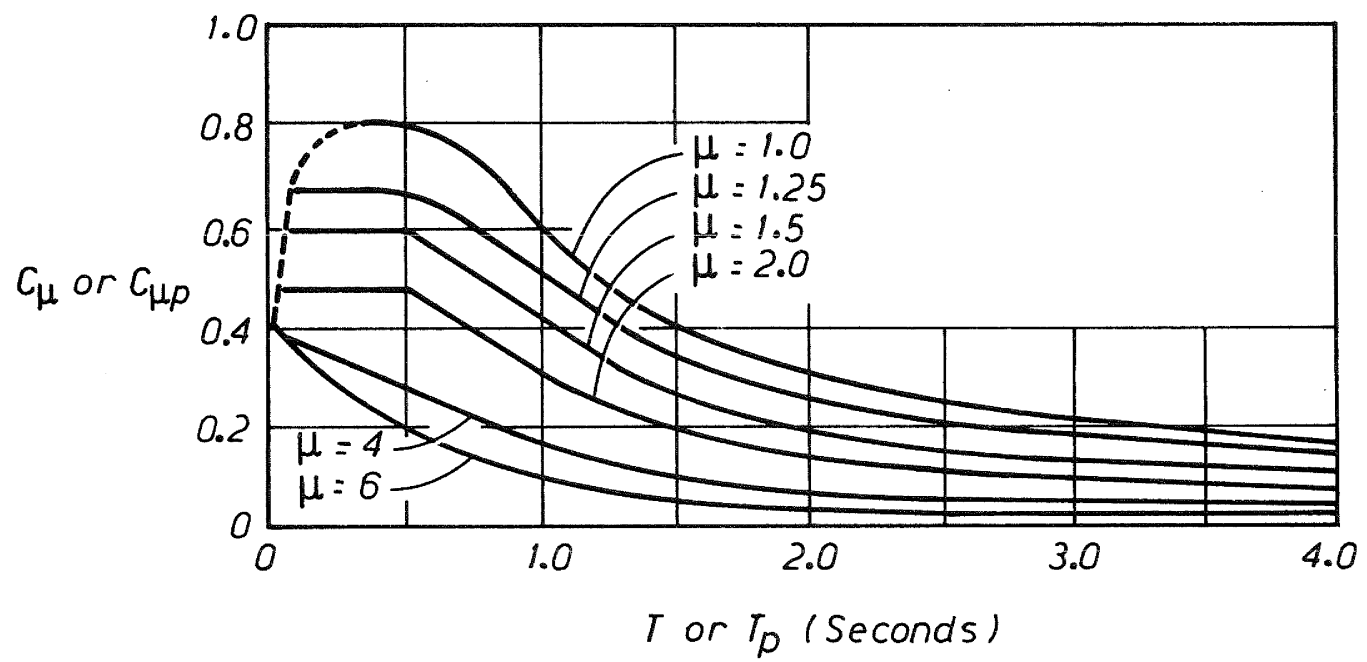

(b) SOFT SOILS

Notes:

1. For structures for parts) with $R=0.4$ to 1.3 values of $C_{\mu}$ (or $C_{\mu p}$ ) need not

2. The dotted portion of the curves shall be used instead of the plateaus to obtain ordinates for elastically responding structures and the ordinates for higher modes of other structures when the dominant response is in the first mode.

Fig. 7 - Basic Seismic Acceleration Coefficients Proposed in the New Draft NZS 4203 [2] 
The definition of "adequate limited ductility" is not stated in the code [1]. An appropriate approximate criterion for "adequate limited ductility", applicable to reasonably regular symmetrical frames without sudden changes in storey stiffness could be: the building as a whole should be capable of deflecting laterally through at least eight load reversals so that the horizontal deflection at the top of the building under the design static seismic loading is at least $\mu$ times that at first yield, without the horizontal load capacity being reduced by more than $20 \%$. The horizontal deflection at first yield should be that calculated assuming elastic behaviour at the design static seismic load. The value of the displacement ductility factor $\mu$ is that associated with the structural type factor $S$ used in the limited ductility design.

The relationship between $S$ and $H$ is often dependent on philosophical considerations. As a simple assumption, in view of the equal maximum displacement concept assumed in deriving the current code seismic loadings, the relationship between $\mu$ and SM could be assumed to be

$$
\mu=\frac{4}{\mathrm{SM}}
$$

where $M=$ either 0.8 for structural steel and reinforced concrete or 1.0 for prestressed concrete and structural masonry, and $S$ = structural type factor used for the structure of limited ductility. For example, for a reinforced concrete frame of limited ductility, where $S=2.0$ and $M=0.8, E q .3$ gives $\mu=2.5$.

It is evident that although a design for limited ductility will mean using higher seismic design loads, the ductility requirements are reduced. For a structure which cannot easily be detailed for ductility, or which is inherently strong due to its structural form and material content, the most economical design may be a structure of Iimited ductility.

\subsubsection{Proposed Draft Replacement for New Zealand Code of Practice for General Structural Design and Design Loadings} for Buildings

The current New Zealand code for general structural design and design loadings for buildings NZS 4203 [1] was written before any of the materials codes had been prepared in a form which recognised the role of the structure in the generation of loading as an earthquake response. Hence the current NZS 4203 contains some provisions that would be more appropriate in materials codes for reinforced concrete, structural timber, timber and masonry.

Essentially single event spectra have been used to estimate peak inertias generated in elastically responding structures for more than forty years (for example, see Ref. 6). There was intensive development of the method in the middle 1950 s (for example, Ref. 7), and subsequent adoption into the building codes of many countries, including New Zealand, of design spectra for horizontal acceleration. The representation in the New Zealand code was idealised and modified to account for the load limiting effects of "fully" ductile structures, and the design rules required augmentation for "Iimited ductility" as previously described.

Hitherto in New Zealand, building code spectra have been adapted from single event spectra or from compounds which contain effects from a small suite of spectra, with each member of the spectra scaled to some control spectrum. While these spectra were the only types available, design for quantified risk could be done (but somehwat unsatisfactorily) by defining a set of control events, magnitude and hypocentral distance, from statistical appraisals of the seismicity of the area surrounding the site of the development under consideration, then choosing appropriate records from a library file of processed earthquake data [8]. Files are maintained at several institutions in the more developed of the world's earthquake prone countries, notably in Japan and USA. The usual result of this kind of study, which has been made for a few New Zealand projects, at least some of which involved structures of "limited" ductility, is a single horizontal spectrum.

A proposed draft replacement for the current loadings code NZS 4203 has been prepared [2] and has been circulated for comment. The proposed draft code will. if adopted in its present form, be the first New zealand general building code to offer a set of uniform risk horizontal acceleration response spectra to be used in seismic design to establish the level of inertia load for which structures should be designed. A summary of the proposed draft code is given in Ref. 9.

The horizontal acceleration response spectra for the loading provisions of the new draft have been determined by the Risk Committee, a group of seismologists, geologists, engineering seismologists and engineers convened by SANZ, which has been working on this project for three or four years. They have made available a set of uniform risk spectra which properly account for the present understanding of New Zealand seismicity and for the nature of the country in modifying earthquake disturbances radiating from sources (see for example Refs. 10 and 11).

The procedure for modifying the seismic force response to account for ductility, that is proposed in the new draft code, uses results from numerical studies to establish the way in which nonlinear behaviour affects peak accelerations. This is a change from the tacit assumption of the current NZS 4203 that accelerations vary inversely with displacement ductility factor at all response frequencies. According to currently accepted ideas of the way that earthquakes affect building structures, the newly specified procedures should successfully predict responses of engineering interest if ductile deformations are reasonably uniformly distributed throughout the structure. 
Table 1 : Values of the Structure Ductility Factor $\mu$ from the Proposed Draft NZS 4203 [2]

\begin{tabular}{|cc}
\hline Elastically Responding Structures & $\underline{\mu}$ \\
$*$ structural steel, prestressed concrete and glued timber & 1.0 \\
$*$ reinforced concrete and reinforced masonry & 1.25 \\
$*$ timber, steel connectors & 1.5
\end{tabular}

Structures of Limited Ductility

braced frames (tension and compression yield)

* structural steel and reinforced concrete

* prestressed concrete

* reinforced masonry and timber with steel connectors

2.5

Yet to be proposed

2

braced frames (tension yielding)

single storey multi-storey

* structural steel, prestressed concrete and reinforced masonry

* reinforced concrete

* timber with steel connectors

Yet to be proposed

1.3

moment resisting frames

* structural steel and reinforced concrete

* prestressed concrete

* reinforced masonry

* timber with steel connectors

3

Yet to be proposed

2.5

structural walls

* structural steel, reinforced concrete and timber with steel connectors

* reinforced masonry

2

coupled structural walls

* structural steel and reinforced concrete

* reinforced masonry and timber with steel connectors

$\begin{array}{cc}\frac{h_{w} / l_{W} \geqq 2}{3} & \frac{h_{w} / l_{W}<1^{+}}{2.5} \\ 2 & 2\end{array}$

$\begin{array}{cc}A \leqq 0.33 & A \geqq 0.67^{+} \\ 2.5 & 3.5 \\ 2 & 2\end{array}$

cantilevered single storey face-loaded walls

* reinforced concrete, prestressed concrete and reinforced masonry

2

Ductile structures

braced frames (tension and compression yielding)

* structural steel and reinforced concrete

* prestressed concrete

* reinforced masonry and timber with steel connectors

4

Yet to be proposed 3.5

moment resisting frames

* structural steel and reinforced concrete

* prestressed concrete

* reinforced masonry

* timber with steel connectors

6

Yet to be proposed

5

structural walls

* structural steel and timber with steel connectors

* reinforced concrete, $\mathrm{h}_{\mathrm{w}} / l_{\mathrm{w}} \geqq 2$

* reinforced masonry, $\mathrm{h}_{\mathrm{w}} / l_{\mathrm{w}} \geqq 2$

4

3.5

coupled structural walls

* structural steel and reinforced concrete

* reinforced masonry

* timber with steel connectors

\begin{tabular}{|c|c|}
\hline & $\begin{array}{c}4 \\
4 \\
3.5\end{array}$ \\
\hline$A \leqq 0.33$ & $A \geqq 0.67^{+}$ \\
\hline 3.5 & $3_{4}^{6} .5$ \\
\hline
\end{tabular}

+ Intermediate values by interpolation. 
Table 1 (Continued)

Notation

In the above table:

$$
A=T \ell / M_{0}
$$

where $T$ = axial load induced in wall by the coupling beams.

$l=$ horizontal length between the centroids of the walls.

$M_{0}=$ total overturning moment at the base of the structure due to the same loads used in the determination of $T$.

$\mathrm{h}_{\mathrm{w}}=$ height from the base of wall to top of uppermost principal storey.

$\ell_{\mathrm{w}}=$ horizontal length of wall in direction of applied load.

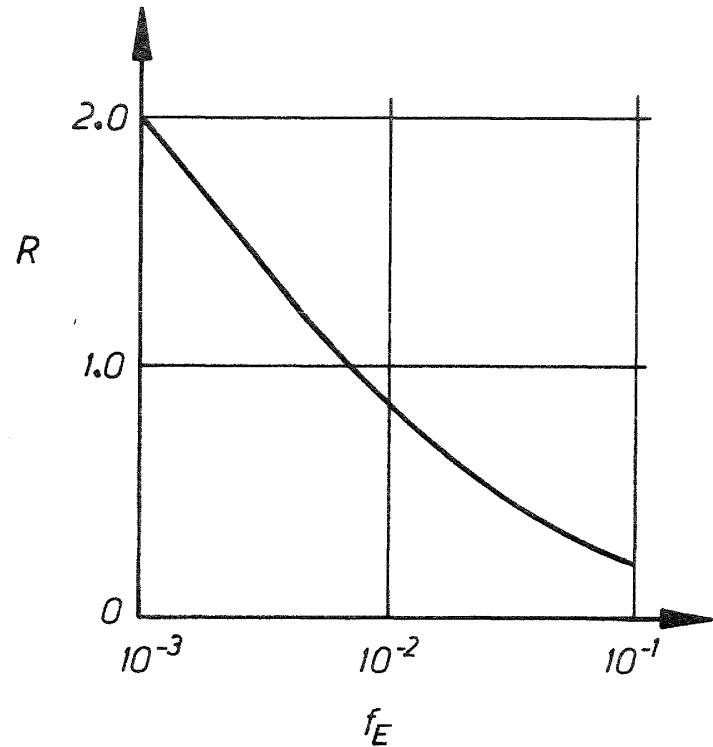

Fig. 8 Relationship Between Risk Factor $R$ and Annual Probability of Exceedence $f_{E}$ proposed in the new Draft NZS 4203 [2]

An unexpected property of the spectra poposed in the new draft code is the geometric similarity of the members of the family. The spectra shapes are surprisingly unaffected by geographical location. The normalised spectra for similar sites in every seismic region are so nearly identical that it has been possible to simplify the presentation of design information.

In the new draft code, when analysis is based on equivalent static forces representing the effect of the actual inertia forces induced by earthquake shaking, the equivalent static forces have the distribution prescribed by the code and the total horizontal seismic force in each direction under consideration is given as

$$
V=C_{\mu} R Z W_{t}
$$

where $C_{\mu}=$ a coefficient read from one of sets of normalised curves. The set is chosen to be appropriate for the soil conditions, the member curve for the degree of structure ductility $\mu$ available and the coefficient value for the structure's prime mode response period. Fig. 7 shows sets of proposed curves. Table 1 lists values for the structure ductility $\mu$ (that is, the displacement ductility factor for the structure) proposed in the new draft code.

$\mathrm{R}=\mathrm{a}$ "risk" factor which modifies the design load when either diminished failure risk is required or enhanced failure risk is acceptable (see Fig.8), varying between 0.4 and 1.3 .

$\mathrm{z}=\mathrm{a}$ "zone" factor accounting for regional seismicity (see Fig.9). 
ZONE FACTOR FOR MAJOR

METROPOLITAN AREAS

AND CHATHAM ISLANDS.

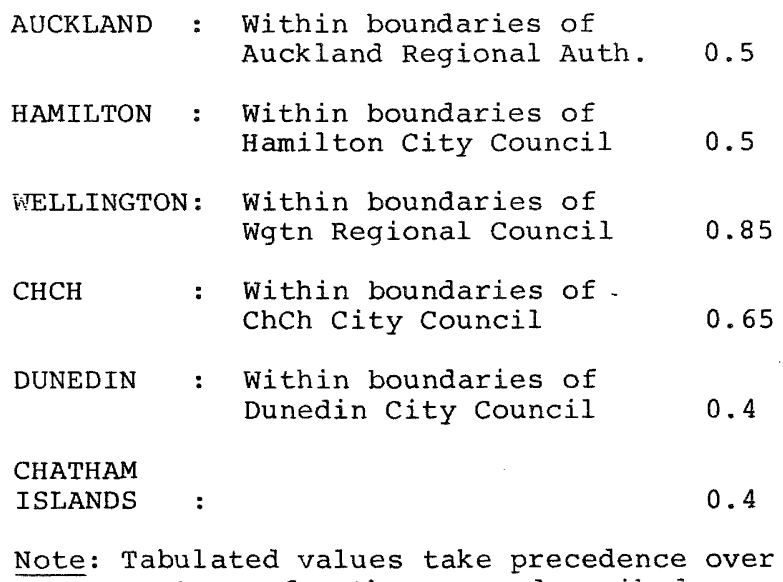

Auckland Regional Auth. 0.5

Hamilton City Council 0.5

$\mathrm{CHCH}$ : Within boundaries of . ChCh City Council

0.65

DUNEDIN

: Within boundaries of Dunedin City Council

0.4

CHATHAM

ISLANDS

Note: Tabulated values take precedence over

Z

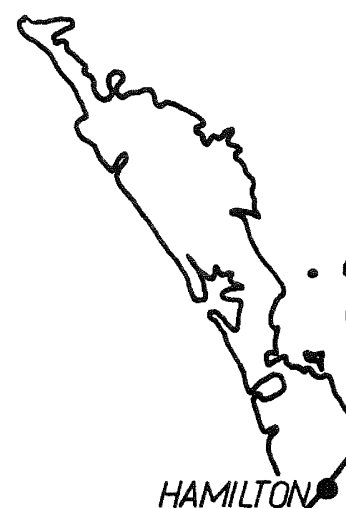

0

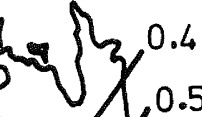

HAMILTON XYURANGA

NEW
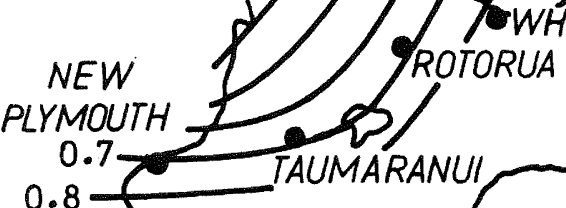
contours for the areas described.

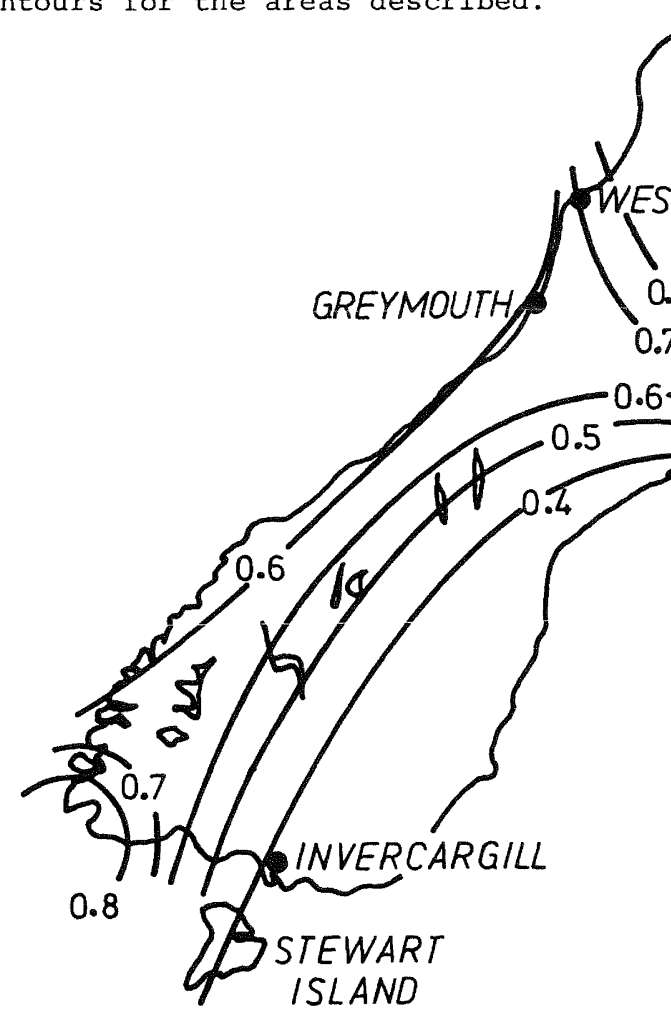

Interpolate linearly

between contours 
$w_{t}=$ gravity load of structure considered to be present during the earthquake.

It is expected that relatively few proposals for limited ductility designs will involve designers in modal response analyses for estimating earthquake generated effects.

It should be noted that the commentary of the New Zealand code for the design of concrete structures [5] contains amplification factors for moments and shears for columns of ductile moment resisting frames, intended to prevent non-uniform distribution of yielding (that is, to prevent column sidesway mechanisms and shear failures) in tall multi-storey moment resisting frames. These amplification factors are applied to the moments and shears obtained using the code seismic and gravity loadings. An increase in these design actions is necessary in the capacity design approach in order to ensure that plastic hinging occurs in the beams of tall frames. Further work is required to produce sets of amplification factors for other types of structures for use in capacity design. Work is also necessary to determine what amplification factors, if any, are necessary for design actions for structures of limited ductility.

\subsection{REINFORCED CONCRETE}

by R. Park, University of Canterbury, Christchurch, and L.M. Robinson, Consulting Engineer, Dunedin.

\subsubsection{Existing New Zealand Design Codes for Moment Resisting Frames and Structural walls of Limited Ductility for Buildings}

NZS 4203:1984 "Code of Practice for General Structural Design and Design Loadings for Buildings" [l] states that "Structures of limited ductility, not specifically designed to ensure ductile flexural yielding through the application of the principles of capacity design, shall be suitably designed and detailed in accordance with the appropriate materials code".

Moment resisting frames of limited ductility having a maximum height of 4 storeys or $18 \mathrm{~m}$, or if the $500 \mathrm{f}$ and wall mass are less than $150 \mathrm{~kg} / \mathrm{m}^{2}$ of floor area a maximum height of 5 storeys or $22.5 \mathrm{~m}$, are assigned a structural type factor of $\mathrm{S}=3.0$. This structural type factor may be compared with the values of $S=0.8$ assigned to "ductile frames". That is, moment resisting frames of limited ductility are designed for seismic forces which are $2.0 / 0.8=2.5$ times the seismic force used for the design of ductile moment resisting frames.

Structural walls of limited ductility are assigned a structural type factor of $S=2.0$. This structural type factor may be compared with the value for ductile cantilever structural walls, which are assigned a value in the range 1.0 to 2.0 , dependent on the number of walls in the direction under consideration and the relative importance of shear deformation as measured by the height/depth aspect ratio. Structural walls of limited ductility are therefore to be designed for seismic forces which are as much as twice the design seismic force for ductile walls.

As is shown subsequently, this comparison of design seismic forces is only pertinent to flexural actions. The required shear strengths of ductile moment resisting frames and structural walls are determined by capacity design, while for moment resisting frames and structural walls of limited ductility, the required shear strengths are specified directly.

NZS 3101:1982 "Code of Practice for the Design of Concrete Structures" [5] has a Section 14 "Seismic Requirements for Structures of Limited Ductility" which is intended to be used with the "General Principles and Requirements" and the "Additional Principles and Requirements for Members Not Designed for Seismic Loading" specified in other sections of the code. The main features of Section 14 for moment resisting frames and for structural walls of limited ductility are:

(a) Capacity design is not required.

(b) Design for concurrent earthquake effects from loadings in two principal directions is not required (a concession relevant to foundation design particularly).

(c) Shear strengths provided are to have a suitable margin over the required flexural strengths (as determined by the structural type factor). Flexural strengths outside the designated end regions are to have a suitable margin over the design moments (as determined by the structural type factor).

(e) Lengths of designated end regions of beams and columns are equal to member depth. The height of the designated end region of structural walls, measured from the base of the wall, is equal to the greater of the horizontal length of the wall and one-sixth of the overall height of the wall. However. of flexural strengths outside of the region so defined do not meet the requirements of (d) above, then the "end region" is designated as the whole length of the beam or column, or the whole height of the wall.

(f) Transverse reinforcement in the designated end regions when required for confinement or for tying of longitudinal bars where this is in two layers and of higher steel ratio, should have spacing not exceeding 10 longitudinal bar diameters. An equation is given for the transverse reinforcement for confinement, if required. Transverse reinforcement for confinement may not be required. In the designated end regions the contribution to shear strength provided by the concrete may be assumed to be not greater than onehalf of that for gravity load design. The spacing of shear reinforcement may not exceed one-quarter of the 
effective depth of the member.

The limited ductility provisions are expected to be used as a matter of convenience for those structures which are inherently strong due to structural form or material content and hence which can be economically designed for high seismic forces, and also for those structures where the designer recognises a limitation to the ductility capacity as a result of structural complexity or irregular form.

2.2.2 Comparison of New Zealand Design Codes for Ductile Frames and Frames of Limited Ductility for Buildings and for Ductile Cantilever Structural Walls and Structural Walls of Limited Ductility in Buildings

Comparison between the main design provisions of New Zealand codes for reinforced concrete ductile moment resisting frames and moment resisting frames of limited ductility are given in Table 2 . Comparisons between the main design provisions for reinforced concrete ductile cantilever structural walls and structural walls of limited ductility are given in Table 3

\subsubsection{Possible Future Developments in the Concrete Design Code}

Accepting the appropriateness of $S=2.0$ for the determination of the basic seismic load and the resulting flexural strength in the end regions of beams and columns of moment resisting frames and structural walls, two matters of importance remain outstanding:

(a) the level of required shear strength and the degree to which concrete shear resisting mechanisms may be assumed to contribute to that shear strength, and

the establishment of appropriate controls to ensure adequate confinement of concrete and tying of longitudinal compression reinforcement so as to promote sufficiently ductile behaviour in flexure.

In these matters Section 14 of NZS 3101 presently treats the design of all members in a uniform manner. This is in recognition of the style of structure often required to be designed of limited ductility: regular cantilever walls, deep-membered frames in nature similar to cantilever walls, but arising from irregular penetration of the walls; and frames of acceptable regularity. Many such structures are not amenable to analysis in sufficient detail to allow the extraction of control parameters, which would be useful for the establishment of general rules, with any meaningful precision. Rules which, for instance, differentiate between columns and walls, or between beams of unusual proportions and beams which are part of wall systems (as spandrels), on a basis which is too categorical may therefore be inappropriate. Such rules must inevitably be on a fairly arbitrary basis and will invariably be tested as to their appropriateness by "special" cases.
There is therefore an apparent conflict between the need for simple, yet adequately cautious, rules, and the need to enable the treatment of special cases. To resolve that difficulty section 14 of the Concrete Design Code would require considerable expansion. Those existing provisions which find widest application without serious cost repercussions, could then be stated more simply, with more general formulations being introduced for use as desired or as required to resolve difficulties resulting from the application of the simpler formulations. At present the accomplishment of this is attempted by allowing the use of capacity design to reduce demands on members.

To allow such procedures, and even to justify the retention of present provisions, extensive research, both experimental and analytical, is urgently required. It is believed that priority for this research should be applied to the subjects listed in (a) and (b) above, and to such fundamental issues as the adequacy of the present provisions for length and location of splices, which are now the same as for gravity or wind loading.

There exists a range of technical literature on the performance during seismic loading of reinforced concrete elements and structural assemblages where the New Zealand code provisions for ductile detailing have not been met. One summary of test results on beam-column joints is given in a report by cook [12]. Further summaries of available test results, analyses, and earthquake damage should be conducted. Tests on a further range of reinforced concrete columns, beam-column joints and structural walls of limited ductility need to be conducted to complement the results already available (for example Ref. 13) and to provide information where none at present exists.

Nonlinear dynamic analyses need to be conducted to determine the curvature ductility demand at the critical sections of frames designed for limited ductility with columns not protected against plastic hinging by capacity design procedures and of structural walls. The degree of confinement necessary in the end regions of columns can be determined using existing procedures (for example, Ref. 14) once the curvature ductility demand to be met has been estab1 ished. 
Table 2 : Seismic Design Provisions for Reinforced Concrete Moment Resisting Frames

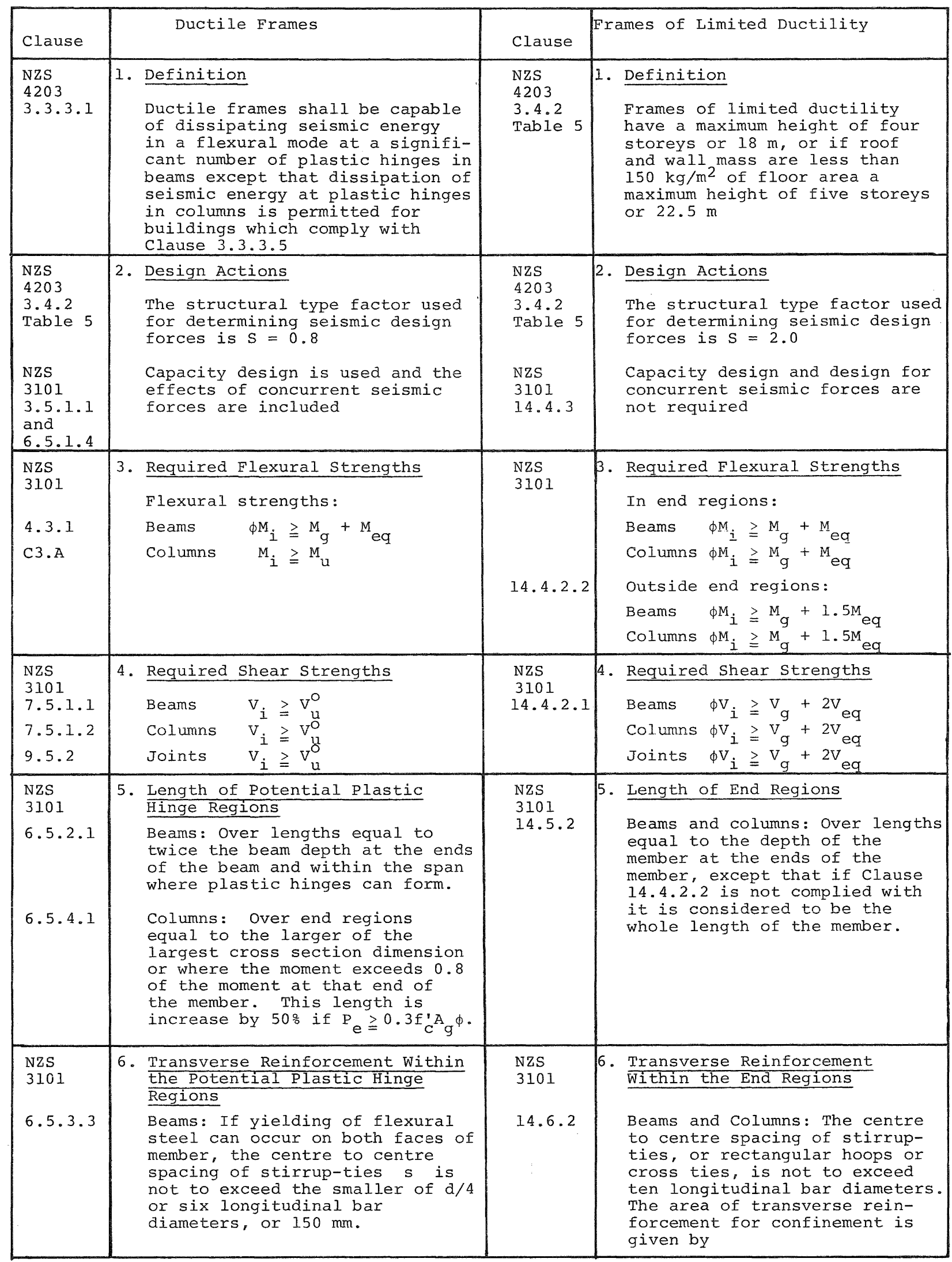


Table 2 (Continued)

\begin{tabular}{|c|c|c|c|}
\hline Clause & Ductile Frames & Clause & Frames of Limited Ductility \\
\hline 6.5 .3 .3 & $\begin{array}{l}\text { The yield force of the stirrup- } \\
\text { tie must at least equal one- } \\
\text { sixteenth of the yield force } \\
\text { of the longitudinal bar or bars } \\
\text { it is to restrain multiplied } \\
\text { by s/loo. } \\
\text { The stirrups must also satisfy } \\
\text { shear strength requirements } \\
\text { computed assuming } v_{c}=0 \text {. }\end{array}$ & & $\begin{array}{l}A_{\text {sh }}=R_{C}\left(0.02 s_{h} h \frac{f_{C}^{\prime}}{f_{y h}}\right) \\
\text { if } \gamma>1.0 \\
\text { where } \gamma=\frac{M^{*}+0.3 P}{0.6 \phi f_{C}^{\prime} A_{g}^{* h}} \leqq 3.0 \\
\text { and } 0 \leqq R_{C}=\left[\frac{\gamma}{1+\rho^{*} m}-1\right] \leqq 1.0\end{array}$ \\
\hline 6.5 .4 .3 & $\begin{array}{l}\text { Columns: The centre to centre } \\
\text { spacing of transverse confining } \\
\text { steel is not to exceed the } \\
\text { smaller of one-fifth of the least } \\
\text { lateral dimension of the cross } \\
\text { section or six longitudinal bar } \\
\text { diameters or } 200 \text { mm. The yield } \\
\text { force of the transverse bar in } \\
\text { rectangular arrangements of } \\
\text { hoop steel must at least equal } \\
\text { one-sixteenth of the yield force } \\
\text { of the longitudinal bar or bars } \\
\text { it is to restrain. The trans- } \\
\text { verse reinforcement must satisfy } \\
\text { the code equations } 6-22 \text { and } 6-23 \\
\text { for spirals or circular hoops or } \\
\text { equations } 6-24 \text { and } 6-25 \text { for } \\
\text { rectangular hoops } \\
\text { The transverse reinforcement } \\
\text { must also satisfy shear strength } \\
\text { requirements computed assuming } \\
v_{c}=0 \text { if P } / f_{c}^{A} \text {. } 0.1 \text { or } v_{c} \\
\text { as given by equation } 7-41 \text { if } \\
P_{e} / f_{c}^{A}>0.1 \text {. }\end{array}$ & 14.7 .2 & $\begin{array}{l}\text { The transverse reinforcement } \\
\text { provided must also satisfy the } \\
\text { shear strength requirements } \\
\text { computed assuming } v \text { is one- } \\
\text { half of that for gravity load } \\
\text { design. } \\
\text { Maximum spacing of shear rein- } \\
\text { forcement is not to exceed } d / 4 \text {. }\end{array}$ \\
\hline $\begin{array}{l}\text { NZS } \\
3101 \\
9.3 \text { and } \\
9.5 \\
\\
5.5 .2 .1 \\
-5,5.2 .2\end{array}$ & $\begin{array}{l}\text { 7. Beam-Column Joints } \\
\text { Shear: Transverse and vertical } \\
\text { reinforcement must satisfy the } \\
\text { shear strength requirements for } \\
\text { horizontal and vertical shear } \\
\text { using equations } 9-1 \text { to } 9-15 \text {. } \\
\text { Anchorage: Longitudinal } \\
\text { reinforcement passing through } \\
\text { interior joint cores should } \\
\text { have diameters not exceeding } \\
\text { that permitted by the code. } \\
\text { Longitudinal beam reinforcement } \\
\text { anchored in column cores or beam } \\
\text { strips shall have anchorage } \\
\text { commencing either at mid-depth } \\
\text { of the column or at } 10 d_{b} \text { from } \\
\text { the column face, unless plastic } \\
\text { hinging is located away from } \\
\text { the column face in which case } \\
\text { anchorage can be considered to } \\
\text { commence at the column face. }\end{array}$ & $\begin{array}{l}\text { NZS } \\
3101\end{array}$ & $\begin{array}{l}\text { 7. Beam-Column Joints } \\
\text { No specific design rules stated. } \\
\text { Use design rules for non-seismic } \\
\text { joints with the full value of } \\
\mathrm{v}_{\mathrm{C}} \text {. }\end{array}$ \\
\hline
\end{tabular}


Table 3 : Seismic Design Provisions for Reinforced Concrete Structural Walls

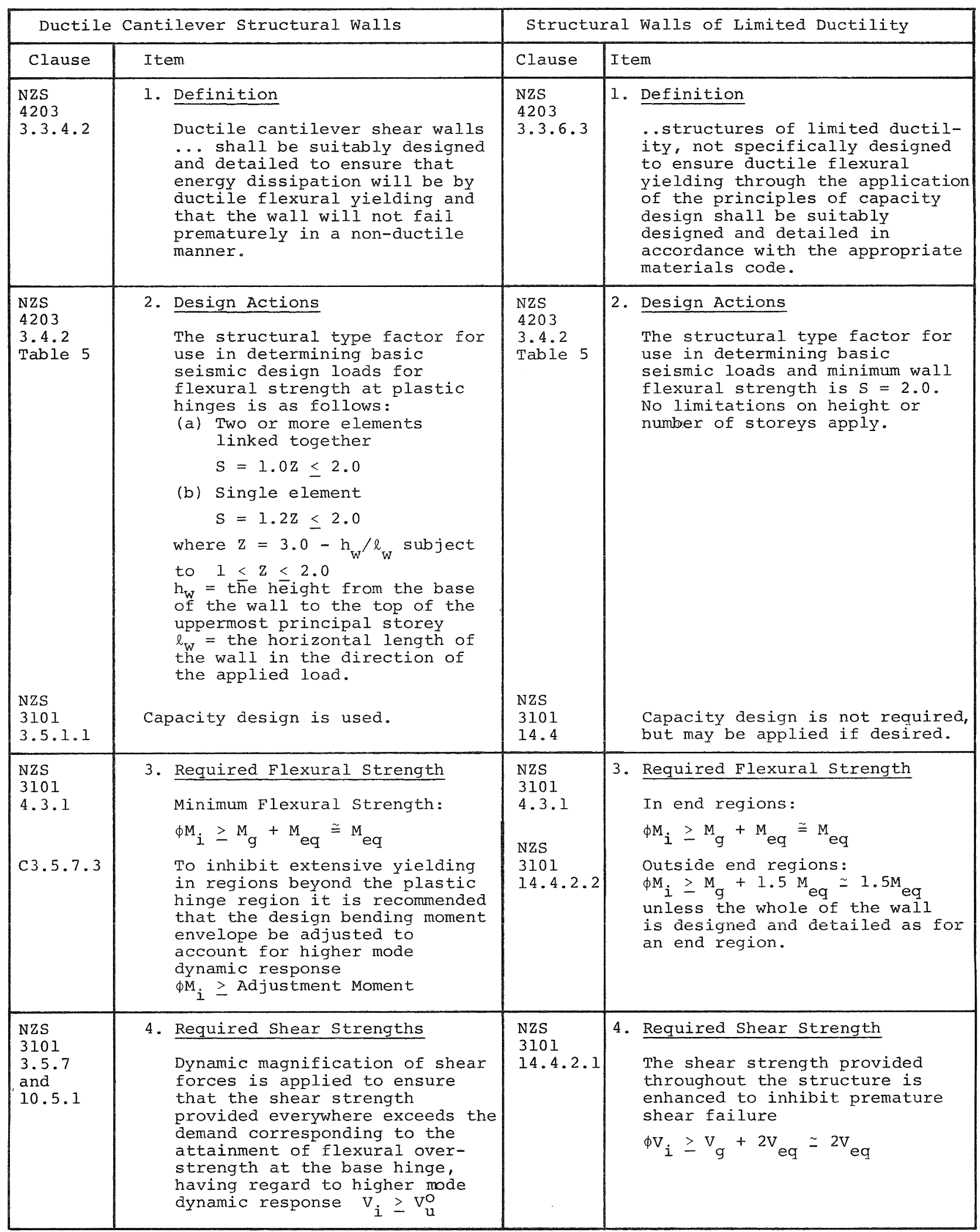


Table 3 (Continued)

\begin{tabular}{|c|c|c|c|}
\hline $\begin{array}{l}\text { NZS } \\
3101 \\
10.5 \cdot 3 \cdot 3 \\
\text { and } \\
10.5 \cdot 4 \cdot 5 \\
\text { (d) }\end{array}$ & $\begin{array}{l}\text { 5. Height of Potential plastic } \\
\text { Hinge Regions } \\
\text { For the region over which special } \\
\text { shear provisions apply, the } \\
\text { height of the potential plastic } \\
\text { hinge region is: the greater of } \\
\text { the horizontal length of the } \\
\text { wall and one-sixth the overall } \\
\text { height of the wall, but need not } \\
\text { be greater than twice the } \\
\text { horizontal length of the walls. } \\
\text { This latter exception does not } \\
\text { apply to regions in which } \\
\text { special transverse confinement } \\
\text { reinforcement is required. }\end{array}$ & $\begin{array}{l}\text { NZS } \\
3101 \\
14.5 .2\end{array}$ & $\begin{array}{l}\text { 5. Height of End Regions } \\
\text { The height of the end region is } \\
\text { specified as the greater of the } \\
\text { horizontal length of the wall, } \\
\text { l } \text { and one-sixth the overall } \\
\text { height of the wall, hw } \text { Where }_{\text {Wh }} \\
\text { the provisions of } 14.4 .2 \text { are } \\
\text { not applied, the height of the } \\
\text { end-region is specified as the } \\
\text { entire height of the wall. }\end{array}$ \\
\hline $\begin{array}{l}\text { NZS } \\
3101 \\
10.5 \cdot 4 \cdot 3 \\
\text { and } \\
10.5 \cdot 4 \cdot 5\end{array}$ & $\begin{array}{l}\text { 6. Transverse Reinforcement Within } \\
\text { the Potential Plastic Hinge } \\
\text { Region } \\
6.1 \text { For Confinement } \\
\text { In regions where either } \\
\text { (a) longitudinal reinforcement } \\
\text { with a steel ratio greater than } \\
2 / \text { fy and arranged in two layers } \\
\text { yields in compression, or } \\
\text { (b) the neutral axis depth at } \\
\text { the attainment of [ideal] } \\
\text { strength exceeds critical values, } \\
\text { then tying of longitudinal bars } \\
\text { to prevent buckling and/or to } \\
\text { confine the concrete is required. } \\
\text { Spacing of this transverse rein- } \\
\text { forcement along the longitudinal } \\
\text { bars should not exceed six times } \\
\text { the diameter of the longitudinal } \\
\text { bars nor, in the case where } \\
\text { confinement is required, the } \\
\text { smaller of one-half the thickness } \\
\text { of the confined rgion of the wall } \\
\text { and l50 mm. Alternate bars } \\
\text { meeting certain spacing criteria } \\
\text { are exempt from tying require- } \\
\text { ments. }\end{array}$ & $\begin{array}{l}\text { NZS } \\
3101 \\
14.6 .2\end{array}$ & 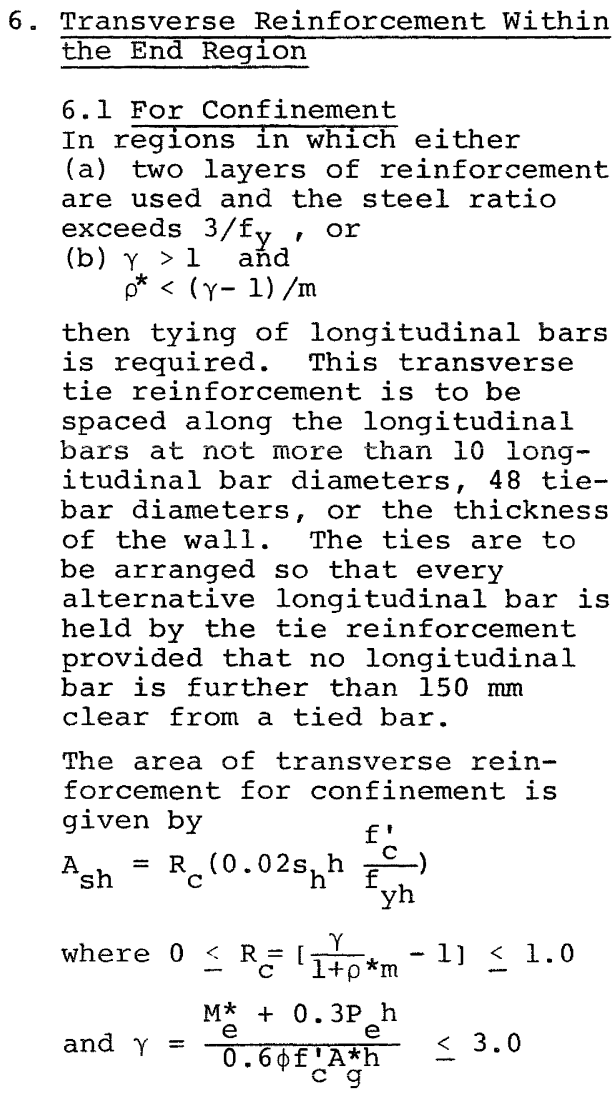 \\
\hline $\begin{array}{l}\text { NZS } \\
3101 \\
7.5 .5\end{array}$ & $\begin{array}{l}6.2 \text { For Shear } \\
\text { The required area of transverse } \\
\text { reinforcement for shear is } \\
\text { computed on the assumption that } \\
v_{C} \text { is not greater than } \\
v_{C}=0.6 \sqrt{\mathrm{P}_{\mathrm{e}} / \mathrm{A}_{\mathrm{g}}}\end{array}$ & $\begin{array}{l}\text { NZS } \\
3101 \\
14.7 .2\end{array}$ & $\begin{array}{l}6.2 \text { For Shear } \\
\text { The required area of transverse } \\
\text { reinforcement for shear is } \\
\text { computed on the assumption that } \\
\mathrm{v}_{C} \text { is one-half that specified } \\
\text { for gravity load design, but } \\
\text { need not be taken less than } \\
\qquad \mathrm{v}_{C}=0.4 \sqrt{\mathrm{P}_{\mathrm{e}} / \mathrm{A}_{\mathrm{g}}}\end{array}$ \\
\hline $\begin{array}{l}\text { NZS } \\
3101 \\
7.3 .14 .9\end{array}$ & $\begin{array}{l}\text { Spacing of horizontal shear } \\
\text { reinforcement is not to exceed } \\
\ell_{W} / 5 \text {, three times the thickness } \\
\text { of the wall, nor } 450 \mathrm{~mm} \text {. }\end{array}$ & $\begin{array}{l}\text { NZS } \\
3101 \\
14.7 .5 \\
\text { and } \\
7.3 .14 .9\end{array}$ & $\begin{array}{l}\text { Spacing of horizontal shear } \\
\text { reinforcement is not to exceed } \\
\text { d/4, l } / 5 \text {, three times the } \\
\text { thickness of the wall, nor } 450 \\
\text { mm. }\end{array}$ \\
\hline
\end{tabular}


Table 3 (Continued)

\begin{tabular}{|l|l|l|}
\hline NZS & 7. Dimensional Limitations \\
10.5.2 & $\begin{array}{l}\text { Unless the compression edge is } \\
\text { continuously supported by stiff } \\
\text { members, such as wall returns, } \\
\text { or the neutral axis depth at } \\
\text { the attainment of flexural } \\
\text { strength is small, the thickness } \\
\text { of any part of structural wall, } \\
\text { of no more than two storeys } \\
\text { height, that is located within } \\
\text { half the neutral axis depth } \\
\text { from the compression edge, is } \\
\text { to be at least one-tenth of } \\
\text { the clear storey height. }\end{array}$ & $\begin{array}{l}\text { No special provisions are given } \\
\text { so the default values relevant } \\
\text { to gravity loaded walls, or the } \\
\text { thickness dictated by strength } \\
\text { apply. Usually wall thickness } \\
\text { is controlled by considerations } \\
\text { of limiting total shear stress } \\
\text { to permitted values. }\end{array}$ \\
\hline
\end{tabular}

\section{$2.3 \quad$ MASONRY}

by M.J.N. Priestley, University of Canterbury, Christchurch

\subsubsection{Existing New Zealand Design Codes for Masonry Buildings of Limited Ductility}

As with concrete structures, loading for limited ductile masonry structures is defined by NZS 4203:1984 "Code of Practice for General Structural Design and Design Loadings for Building" [1]. Sections 2.2.1 and 2.2.2 include the definitions from NZS 4203 of limited ductile moment resisting frames and structural walls respectively.

NZS 4230P "Provisional Code of Practice for Masonry Design" [15], which has recently been promulgated includes provisions for fully ductile and limited ductile structures. Drafting of the seismic design provisions of the masonry code was strongly influenced by the following three constraints:

(a) Most masonry structures will be unconfined, whereas equivalent ductile or limited ductile concrete structures will have special confinement detailing in potential hinge regions of beams, columns and structural walls. It is difficult to confine masonry elements effectively because of the limited grout space, and the typically high ratio of masonry module height to element thickness. However, it has been shown that a degree of confinement can be obtained by mortar bed confining plates $[16,17]$. Use of such plates will inevitably be unpopular, and most masonry will continue to be unconfined.

Because of these considerations, masonry is rather different to concrete. The norm in seismic design of concrete structures will be to ensure adequate ductility by following conservative confining rules. The norm in masonry will be a total lack of confinement. Consequently masonry structures will have a limited ductility in a rather different sense than concrete structures. (b) Compatibility with NZS 4203 [1], which stated that fully ductile masonry structures could be designed. This implies, for example, that ductile masonry frames with $S=0.8$ are acceptable.

(c) A desire for compatibility of format with NZS 3101 [5], the Concrete Design Code, which includes a special section (Chapter 14) on seismic design of structures of limited ductility. Since the arguments advanced above imply that all masonry structures have limited ductility, the approach taken in the masonry code has been to use Chapter 14 to provide simplified rules for simple masonry structures designed to conservative Structural Type factors.

Ductility capacity is based on analyses using an ultimate compression strain of $\varepsilon=0.0025$ for unconfined masonry, and a higher ultimate compression strain of $\varepsilon=0.008$ for sections incorporating $3 \mathrm{~mm}$ thick mortar bed confining plates in critical compression regions. The compression stress blocks appropriate for unconfined and confined masonry are shown in Fig. 10. These are needed for assessing ultimate flexural strength, and also for defining the depth $c$ of the compression zone. The ductility capacity is then related to the ultimate curvature

$$
\phi_{\mathrm{u}}=\frac{\varepsilon_{\mathrm{cu}}}{\mathrm{c}}
$$

by geometric considerations.

The designer is required to establish that the ductility capacity of a given masonry structure, as limited by these ultimate compression strains, is appropriate for the structural type factor chosen, that is

$$
\mu \geq \frac{4}{S M}
$$

where the Materials Factor, M, for masonry is $M=1.0[1]$. 
This requires extra design sophistication than required for concrete design. However, design charts $[18,19]$ are available for masonry walls, relating ductility to material strength, wall aspect ratio, axial load and reinforcement levels. Figure 11 shows a typical dimensionless ductility chart giving structural displacement ductility capacity for unconfined masonry walls of aspect ratio (height/length) $=3$. For other aspect ratios $\left(A_{T}\right)$, the displacement ductility capacity is related to the value $\mu_{3}$ for the wall of aspect ratio $A_{T}=3$ by the expression

$$
\mu=1+\frac{3.43\left(\mu_{3}-1\right)\left(1-.375 / A_{T}\right)}{A_{T}}
$$

As an alternative method, the provisional masonry code has simple 'quick check' rules limiting the extent, $c$, of the flexural compression zone at ultimate moment. Equation 5 indicates that reducing c to small values will increase the ultimate curvature, and hence the displacement ductility capacity. For example, the limitation for unconfined ductile masonry cantilever walls less than 3 storeys high is

$$
\mathrm{c} \leq 0.1 \mathrm{~S} l_{\mathrm{w}}
$$

where $\ell$ is the wall length and $S$ is the structural type factor [1].

Similar limitations are imposed for the compression zones of plastic hinge regions or column plastic hinge regions. The rules are conservative but ensure adequate ductility for the specified $\mathrm{S}$ factor.

The limited ductile provisions of Chapter 14 of the provisional masonry code NZS 4203P [15] have been established as a means for setting simplified design rules for minor structures where the cost penalties of designing for higher $S$ factors are less than the cost advantages accruing from simple direct design. The chapter is based on the equivalent chapter in the Concrete Design Code [5], but is shorter, has relatively few limitations, and does not introduce new symbols or concepts to the designer. The provisions are expected to be used as a matter of design convenience, for minor structures, but also for more major structures where the designer recognises a special limitation to ductility capacity of his structure, as a result of structural complexity or irregular form.

\subsubsection{Comparison of New Zealand Code Provisions for Ductile and Limited Ductile Masonry Buildings}

NZS 4230P [15] contains a large number of provisions for fully ductile structures, but comparatively few for limited ductile structures. In many cases, such as spacing limitations for horizontal and vertical reinforcement the provisions are identical, and to avoid unnecessary duplication, these cases are not included in the comparative list, Table 4.

\subsubsection{Possible Future Developments in the Masonry Design Code}

The masonry design code [15] is a provisional document at time of writing and is likely to be adopted without signigicant modification early in 1987 as a full code. It is unlikely that significant changes to the code will be made for several years while the design profession gathers experience in its use.

Areas in which developments are likely include:

Refinement of design equations for masonry shear strength mechanisms. At present no allowance is made for shear carried by masonry in potential plastic hinge regions, of ductile masonry structures, regardless of axial load level. This is known to be conservative, but until further extensive testing is carried out, the current conservative rules are likely to remain.

(ii) Provisions for ductile and limited ductile masonry frames. Insufficient test data are available to allow relaxation of the rather stringent provisions for masonry joints, though these again are known to be conservative. Again, relaxation of the provisions will have to await further testing.

(iii) Ultimate compression strain. The ultimate compression strain for unconfined masonry is set at 0.0025 , based on tests of concrete hollow unit masonry prisms. It is probable that a higher value applies to clay brick masonry, but again, codification will necessarily await the results of further experimental work.

\subsection{STRUCTURAL STEEL}

by K.C.F. Spring, Consulting Engineer, Wellington.

\subsubsection{Existing New Zealand Design Codes for Limited Ductility in Buildings}

NZS 4203:1984 "Code of Practice for General Structural Design and Design Loadings for Buildings" [1] in clause 3.3.6 and Table 5 define strength requirements for buildings, height limitations and refer to the relevant materials code for structures designed for limited ductility.

Unfortunately the current code for the design of steel structures NZS 3404 1977 "Code for Design of Steel Structures [21] provides no criteria for the design of limited ductility structures. It was regarded as an interim code which would subsequently be replaced by a more detailed code following the introduction of limit state design procedures. As a result it was widely recognised that in many areas, an urgent updating of the basis for the design of steel structures was required. 


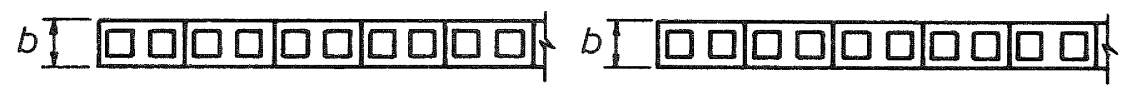
Wall Section Wall Section

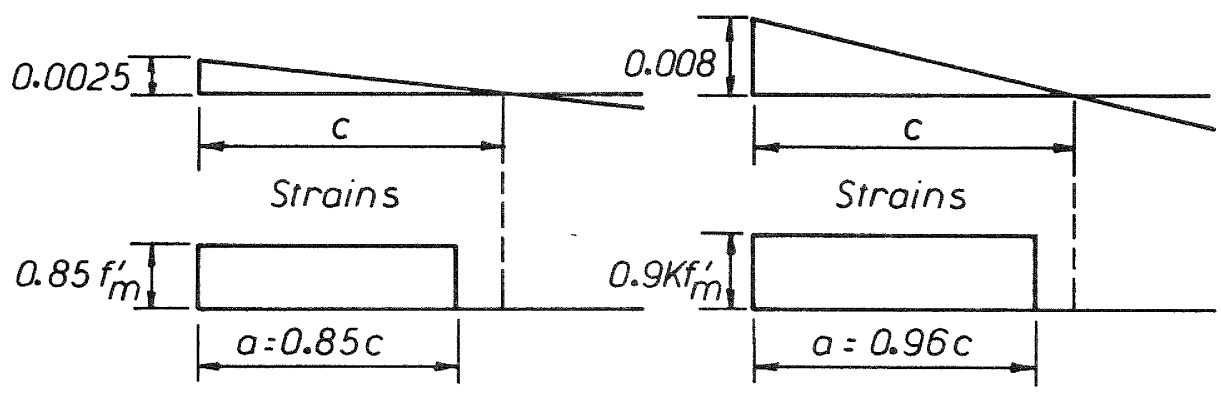

Equivalent Siress Block

Equivalent Siress Block

(a) UNCONFINED MASONRY

(b) CONFINED MASONRY

( $p_{S}=0.00766$ )

Fig. 10 - Equivalent Rectangular Stress Blocks

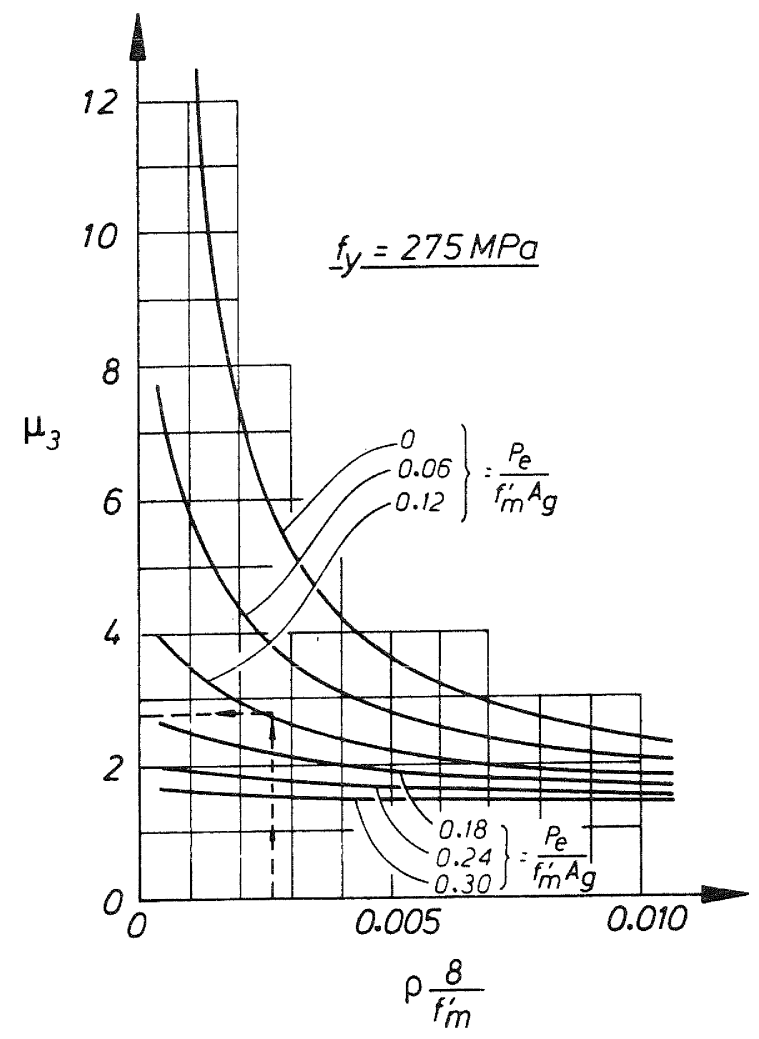

Fig. 11 - Ductility of Unconfined Masonry Wall of Aspect Ratio $h_{w} / l_{w}=3\left(\rho=A_{s t} / l_{w} b\right)$ 
TABLE 4 : Seismic Design Provisions for Masonry Buildings

\begin{tabular}{|c|c|c|c|}
\hline \multicolumn{2}{|r|}{ Ductile Masonry Structures } & \multicolumn{2}{|r|}{ Limited Ductile Masonry Structures } \\
\hline Clause & & Clause & \\
\hline NZS 4203 & $\begin{array}{l}\text { 1. Definition } \\
\text { See Tables } 1 \text { and } 2 \\
\text { (Definitions in NZS } 4203 \text { are materials } \\
\text { independent) }\end{array}$ & $\begin{array}{l}\text { NZS } 4230 \mathrm{P} \\
14.4 .2\end{array}$ & $\begin{array}{l}\text { 1. Definition } \\
\text { Limited ductile masonry buildings must not } \\
\text { exceed three storeys in height, or four } \\
\text { storeys with a light roof as defined in } \\
\text { NZS } 4229[20]\end{array}$ \\
\hline $\begin{array}{l}\text { NZS } 4203 \\
3.4 .2 \\
\text { Table } 5 \\
\text { NZS } 4230 \\
3.6 .3 .4 \\
3.6 .2 .2\end{array}$ & $\begin{array}{l}\text { 2. Design Actions } \\
\text { Masonry Frames : } s=0.8 \\
\text { Masonry Structural Walls : } 1 \leq s \leq 2 \\
\text { (See Table 2, Item 2) } \\
\text { Redistribution of design actions is not } \\
\text { permitted } \\
\text { Capacity design is used and the effects } \\
\text { of concurrent seismic forces are } \\
\text { included where appropriate }\end{array}$ & $\begin{array}{l}\text { NZS } 4203 \\
3.4 .2 \\
\text { Table } 5 \\
\text { NZS } 4230 \text { P } \\
14.4 .3 .3 \\
14.4 .4\end{array}$ & $\begin{array}{l}\text { 2. Design Actions } \\
\text { The Structural Type factor used for determining } \\
\text { seismic design forces is } S=2.0 \\
\text { Redistribution of design actions is not permitted } \\
\text { Capacity design and design for concurrent seismic } \\
\text { forces are not required }\end{array}$ \\
\hline $\begin{array}{l}\text { NZS } 4230 P \\
4.3 .1 .1 \\
4.3 .2\end{array}$ & $\begin{array}{l}\text { 3. Required Flexural Strengths } \\
\text { Ductile Frames : } \\
\text { Beams } \phi M_{i} \geq M_{g_{o}}+M_{e q} \\
\text { Columns } M_{i} \geq M_{u} \\
\text { Structural Walls : } \phi M_{i} \geq M_{g^{\prime}}+M_{e q} \\
\text { Moment diagram is adjusted from the code- } \\
\text { load moment distribution to allow for higher } \\
\text { mode effects }\end{array}$ & $\begin{array}{l}\text { NZS } 4230 \mathrm{P} \\
14.4 .32\end{array}$ & $\begin{array}{l}\text { 3. Required Flexural strengths } \\
\text { In end regions } \\
\phi M_{i} \geq M_{g}+M_{e q} \\
\text { Outside end regions } \phi M_{i} \geq M_{g}+1.5 M_{e q} \\
\phi M_{i} \geq M_{g}+1.5 M_{e q}\end{array}$ \\
\hline $\begin{array}{l}\text { NZS } 4230 \mathrm{P} \\
7.5 .1\end{array}$ & $\begin{array}{l}\text { 4. Required Shear Strength } \\
\text { Beams, Columns, Joints, } \\
\text { Structural walls : } \mathrm{v}_{\mathrm{i}} \geq \mathrm{v}_{\mathrm{u}}^{\circ}\end{array}$ & $\begin{array}{l}\text { NZS } 4230 \mathrm{P} \\
14.4 .3 .1\end{array}$ & $\begin{array}{l}\text { 4. Required Shear Strength } \\
\text { Beams, Columns, Joints, Structural walls : } \\
\phi \mathrm{v}_{\mathrm{i}} \geq \mathrm{v}_{\mathrm{g}}+2 \mathrm{v}_{\mathrm{eq}}\end{array}$ \\
\hline $\begin{array}{l}\text { NZS4230P } \\
10.5 .13\end{array}$ & 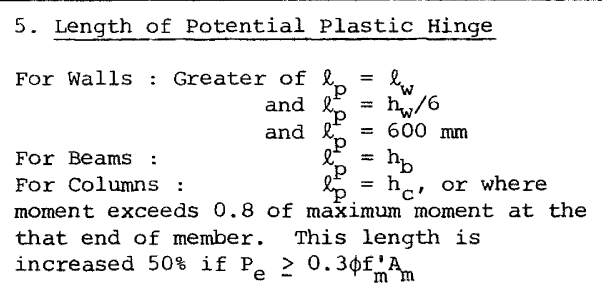 & $\begin{array}{l}\text { NZS } 4230 P \\
14.5 .1\end{array}$ & 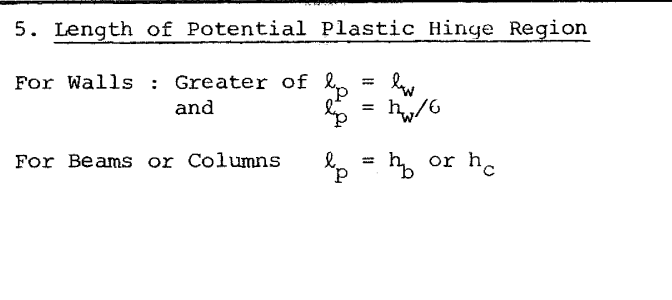 \\
\hline $\begin{array}{l}\text { NZS } 4230 \mathrm{P} \\
10.5 .5\end{array}$ & 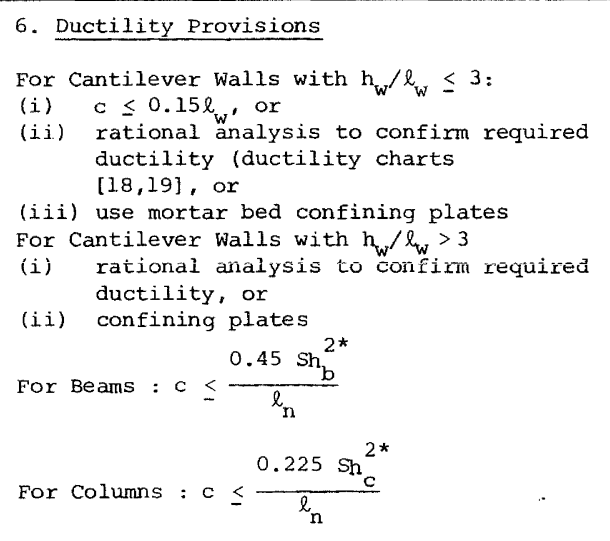 & $\begin{array}{l}\text { NZS } 4230 \mathrm{P} \\
14.6 .2\end{array}$ & $\begin{array}{l}\text { 6uctility Provisions } \\
\text { For Cantilever Walls } \\
c \leq 0.25 l_{\mathrm{w}} \\
\text { For Beams } \mathrm{c} \leq \frac{0.9 \mathrm{~h}_{\mathrm{b}}^{2}}{l_{\mathrm{n}}} \\
\text { For Columns } \mathrm{c} \leq 0.45 \mathrm{~h}_{\mathrm{c}}^{2} / l_{\mathrm{n}}\end{array}$ \\
\hline $\begin{array}{l}\text { NZS } 4230 \mathrm{P} \\
7.5 .1 .1\end{array}$ & $\begin{array}{l}\text { 7. Shear Reinforcement } \\
\text { Within plastic hinge regions all shear to } \\
\text { be resisted by shear reinforcement, unless } \\
\text { ideal shear strength corresponds to } \\
\text { SM }>3 \text {, in which case linear increase } \mathrm{v}_{\mathrm{m}} \\
\text { to the full non-ductile value at } \mathrm{SM}=4 \\
\text { is permitted. } \\
\text { Spacing of reinforcement within potential } \\
\text { plastic hinge region shall not exceed } \\
\frac{1}{4} \text { of member depth }\end{array}$ & $\begin{array}{l}\text { NZS } 4230 \mathrm{P} \\
14.7 .2 .1 \\
14.7 .2 .2\end{array}$ & $\begin{array}{l}\text { 7. Shear Reinforcement } \\
\text { Within potential plastic hinge regions } v_{\mathrm{m}} \text { is } \\
\text { taken as } \frac{1}{2} \text { the value given for non-hinging } \\
\text { regions. } \\
\text { Spacing of reinforcement within potential } \\
\text { plastic hinge region shall not exceed } \frac{1}{4} \text { of } \\
\text { member depth }\end{array}$ \\
\hline
\end{tabular}

* Note Provision code has typographical errors in these equations. 
Table 5 : Seismic Design Provisions for Structural Steel Buildings

\begin{tabular}{|c|c|c|c|}
\hline \multicolumn{2}{|r|}{ Ductile Systems } & \multicolumn{2}{|r|}{ Limited Ductile Systems } \\
\hline Ref. & & Ref. & \\
\hline $\begin{array}{l}\text { NZS } 4203 \\
3.3 .3 .1\end{array}$ & $\begin{array}{l}\text { 1. Definition } \\
\text { Ductile systems may be designed } \\
\text { to dissipate energy in varying } \\
\text { modes providing the criteria } \\
\text { noted below to prevent brittle } \\
\text { failure are applied. }\end{array}$ & $\begin{array}{l}\text { NZS } 4203 \\
3.4 .2 \\
\text { Tabie } 5 \\
\text { Items } 4 \\
\text { and } 5\end{array}$ & $\begin{array}{l}\text { 1. Definition } \\
\text { Frames of limited ductility have } \\
\text { a maximum height of four storeys } \\
\text { or } 18 \mathrm{~m} \text {, or if the roof and wall } \\
\text { mass are less than } 150 \mathrm{~kg} / \mathrm{m}^{2} \text { of } \\
\text { floor area a maximum height of } \\
\text { five storeys or } 22.5 \mathrm{~m} \text {. } \\
\text { However the steel study group } \\
\text { were of the opinion that for } \\
\text { Moment Resisting Frames where } \\
\text { the height exceeded the limit- } \\
\text { ations of Nas } 4203 \text { and where } \\
\text { drift limitations dictated } \\
\text { member size then the criteria } \\
\text { for limited ductile design would } \\
\text { be appropriate. }\end{array}$ \\
\hline $\begin{array}{l}\text { NZS } 4203 \\
3.4 .2 \\
\text { Table } 5 \\
\text { NZNSEE } \\
\text { Vol.18 } \\
\text { No.4 } \\
\text { P.329 }\end{array}$ & $\begin{array}{l}\text { 2. Design Action } \\
\text { The structural type factor } \\
\text { used for determining seismic } \\
\text { design forces } \\
\quad \leq \leqq 2.0 \\
\text { Capacity design is used and } \\
\text { the effects of concurrent } \\
\text { seismic forces are included. }\end{array}$ & $\begin{array}{l}\text { NZS } 4203 \\
3.4 .2 \\
\text { Table } 5 \\
\text { NZNSEE } \\
\text { Vol.18 } \\
\text { NO. } 4 \\
\text { P. } 329\end{array}$ & $\begin{array}{l}\text { 2. Design Action } \\
\text { The global ductility damand on } \\
\text { limited ductility frames is } \\
\text { limited to } \mu \leq 2.5 \text { resulting in } \\
\text { a range of structural type } \\
\text { factors for limited ductility } \\
\text { of } 2 \leq \mathrm{s} 5 \text { to } 6 \text {. } \\
\text { Capacity design is not required } \\
\text { for limited ductile structures } \\
\text { that have a maximum height of } \\
\text { four storeys or } 18 \mathrm{~m} \text { (or of the } \\
\text { roof wall mass are less than } \\
\text { l50 kg/m } 2 \text { of floor area a maxi- } \\
\text { mum height of five storeys or } \\
22.5 \mathrm{~m} \text {. However the effects of } \\
\text { concurrent seismic forces must } \\
\text { be considered in corner columns } \\
\text { and other critical column where } \\
\text { applicable. } \\
\text { Limited ductile structures } \\
\text { exceeding the above height } \\
\text { restrictions must be designed } \\
\text { using capacity design procedures } \\
\text { with the effects of concurrent } \\
\text { seismic forces considered in all } \\
\text { columns where applicable. }\end{array}$ \\
\hline & $\begin{array}{l}\text { 3. Moment Resisting Frames } \\
\text { 3.1 } \\
\text { 3.1.1 Reams } \\
M_{p} \geqq M_{u}\end{array}$ & & 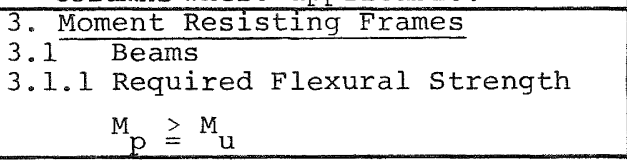 \\
\hline $\begin{array}{l}\text { NZNSEE } \\
\text { VO1. } 18 \\
\text { NO. } 4 \\
\text { P. } 341\end{array}$ & 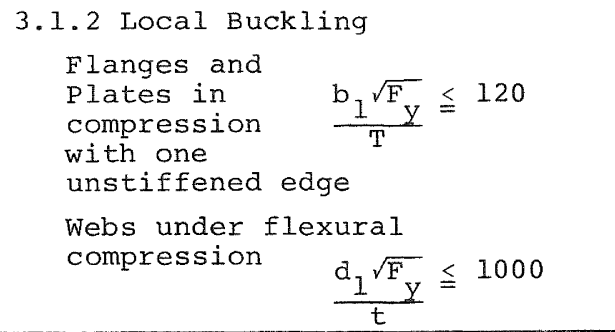 & $\begin{array}{l}\text { NZNSEE } \\
\text { VO1. } 18 \\
\text { No. } 4 \\
\text { P. } 341\end{array}$ & 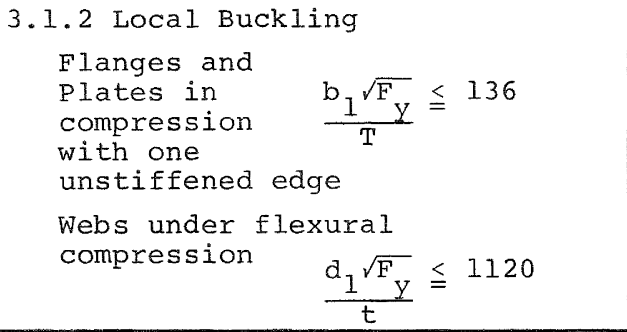 \\
\hline $\begin{array}{l}\text { NZNSEE } \\
\text { Vo. } 18 \\
\text { No. } 4 \\
\text { P. } 341\end{array}$ & 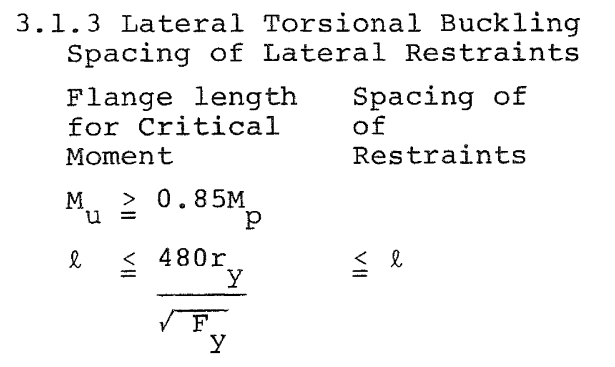 & $\begin{array}{l}\text { NZNSEE } \\
\text { VO1. } 18 \\
\text { No. } 4 \\
\text { P. } 341\end{array}$ & 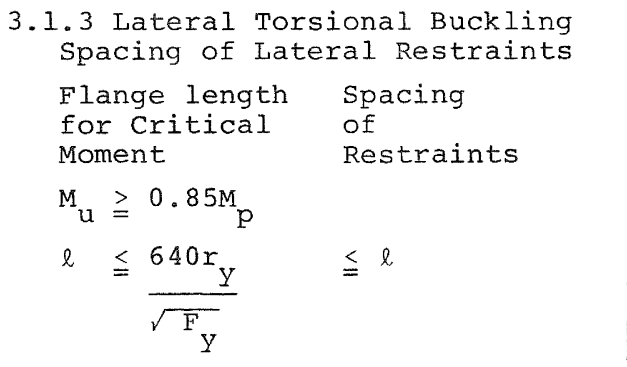 \\
\hline
\end{tabular}


Table 5 (Continued)

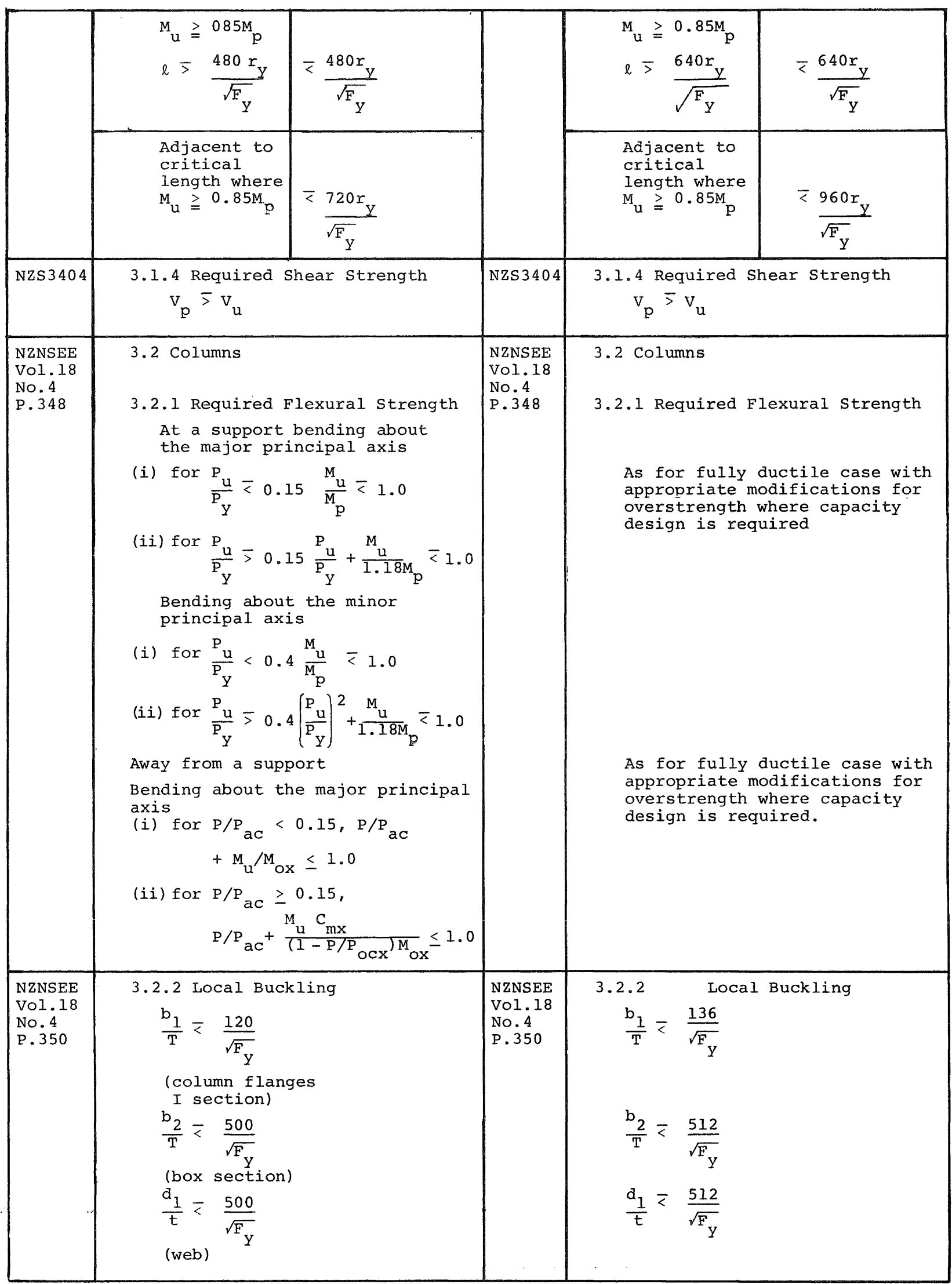


Table 5 (Continued)

\begin{tabular}{|c|c|c|c|c|c|}
\hline \multirow{4}{*}{$\begin{array}{l}\text { NZNSEE } \\
\text { VOI. } 18 \\
\text { No. } 4 \\
\text { P. } 350\end{array}$} & \multicolumn{2}{|c|}{$\begin{array}{r}\text { 3.2.3 Lateral Torsional Buckling } \\
\text { Spacing of Lateral Restraints }\end{array}$} & \multirow{4}{*}{$\begin{array}{l}\text { NZNSEE } \\
\text { Vol.18 } \\
\text { No. } 4 \\
\text { P.35 }\end{array}$} & \multicolumn{2}{|c|}{$\begin{array}{l}\text { 3.2.3 Lateral Torsional Buckling } \\
\text { Spacing of Lateral Restraints }\end{array}$} \\
\hline & $\begin{array}{l}\text { Flange length } \\
\text { for Critical } \\
\text { Moment } \\
M>0.85 \mathrm{M} \\
l<\frac{480 \propto \mathrm{r} y}{\sqrt{\mathrm{F}_{\mathrm{y}}}}\end{array}$ & $\begin{array}{l}\text { Spacing of } \\
\text { Restraints } \\
\quad<\ell\end{array}$ & & $\begin{array}{l}\text { Flange length } \\
\text { for Critical } \\
\text { Moment } \\
M \overline{>} 0.85 \mathrm{M} \\
\ell<\frac{640 \propto \mathrm{r} y}{F_{y}}\end{array}$ & $\begin{array}{l}\text { Spacing of } \\
\text { Restraints } \\
\qquad \overline{<} \ell\end{array}$ \\
\hline & $\begin{array}{l}\mathrm{M}>0.85 \mathrm{M}_{\mathrm{pc}} \\
\ell>\frac{480 \propto \mathrm{r}_{\mathrm{y}}}{\sqrt{\mathrm{F}_{\mathrm{y}}}}\end{array}$ & $\overline{<} \frac{480 \propto r y}{\sqrt{F_{y}}}$ & & $\begin{array}{l}\mathrm{M}>0.85 \mathrm{Mpc}_{\mathrm{pc}} \\
\ell>\frac{640 \propto \mathrm{r}_{\mathrm{Y}}}{\sqrt{\mathrm{F}_{\mathrm{Y}}}}\end{array}$ & $\frac{640 \propto r y}{\sqrt{F_{y}}}$ \\
\hline & \multicolumn{2}{|c|}{$\begin{array}{l}\text { where } \propto=\frac{1.5}{\sqrt{1+\frac{R}{8}}} \\
\text { and } R=24\end{array}$} & & \multicolumn{2}{|c|}{$\begin{array}{l}\text { where } \propto=\frac{1.5}{\sqrt{1+\frac{R}{8}}} \\
\text { and } R=10\end{array}$} \\
\hline & \multicolumn{2}{|c|}{$\begin{array}{l}\text { 3.2.4 Connections-stiffeners } \\
\text { The designs of the tension and } \\
\text { compression stiffeners in beams } \\
\text { to column moment-resisting } \\
\text { connections is based on an } \\
\text { overstrength of } 1.5 \text { times the } \\
\text { nominal yield strength of the } \\
\text { member actions, where the } \\
\text { members framing into the } \\
\text { connection will yield under } \\
\text { the combination of earthquake } \\
\text { and gravity loading. Where } \\
\text { these members will not yield } \\
\text { under the appropriate combi- } \\
\text { nations of earthquake and } \\
\text { gravity loading then the } \\
\text { design forces input into the } \\
\text { connection should be deter- } \\
\text { mined by rational analysis. }\end{array}$} & & \multicolumn{2}{|c|}{$\begin{array}{l}\text { 3.2.4 Connections-Stiffeners } \\
\text { The design of the tension and } \\
\text { compression stiffeners in beam } \\
\text { to column moment-connections is } \\
\text { to be based on an overstrength } \\
\text { of } 1.35 \text { times the nominal yield } \\
\text { strength of the member actions, } \\
\text { where the members framing into } \\
\text { the connection will yield under } \\
\text { the combination of earthquake } \\
\text { and gravity loading. Where } \\
\text { these members will not yield } \\
\text { under the appropriate combi- } \\
\text { nations of earthquake and } \\
\text { gravity loading then the design } \\
\text { forces input into the connection } \\
\text { should be determined by rational } \\
\text { analysis. }\end{array}$} \\
\hline $\begin{array}{l}\text { NZNSEE } \\
\text { VOI. } 18 \\
\text { No. } 4 \\
\text { P. } 377\end{array}$ & \multicolumn{2}{|c|}{ 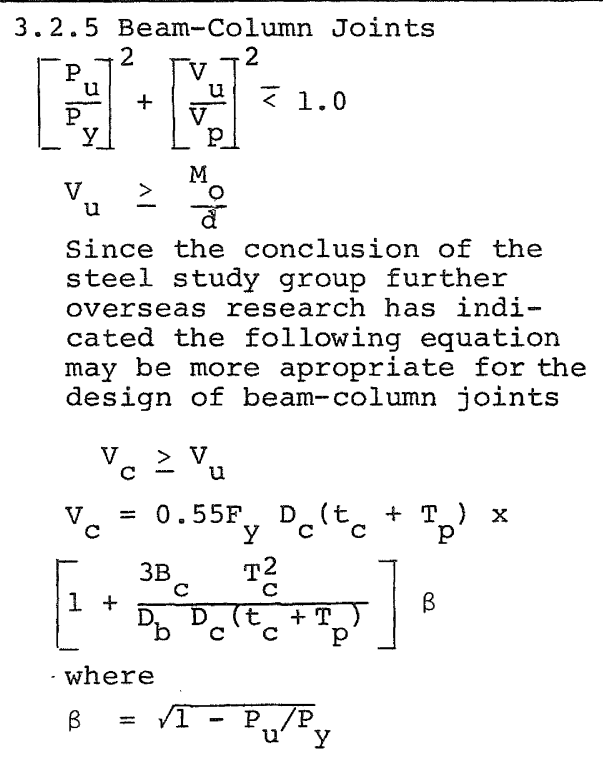 } & $\begin{array}{l}\text { NZNSEE } \\
\text { Vol. } 18 \\
\text { No. } 4 \\
\text { P. } 377\end{array}$ & \multicolumn{2}{|c|}{$\begin{array}{c}3.2 .5 \text { Beam-Column Joints } \\
\text { As for ductile case }\end{array}$} \\
\hline
\end{tabular}


Table 5 (Continued)

\begin{tabular}{|c|c|c|c|}
\hline $\begin{array}{l}\text { NZNSEE } \\
\text { Vol. } 18 \\
\text { No. } 4 \\
\text { P. } 345\end{array}$ & $\begin{array}{l}\text { 3.2. Column Hinging } \\
\text { Hinges in columns must not } \\
\text { form away from the ends of } \\
\text { a column unless the full } \\
\text { length of column is braced } \\
\text { as for a plastic hinge } \\
\mathrm{P}_{\mathrm{u}} \leq 0.5 \leqq \frac{1+\beta-\lambda}{1+\beta+\lambda} \\
\overline{\mathrm{P}_{\mathrm{Y}}}=0 .\end{array}$ & $\begin{array}{l}\text { NZNSEE } \\
\text { VOl. } 18 \\
\text { No. } 4 \\
\text { P. } 345\end{array}$ & $\begin{array}{l}\text { 3.2.6 Column Hinging } \\
\text { Hinges in columns must not form } \\
\text { away from the ends of a column } \\
\text { unless the full length of column } \\
\text { is braced as for a plastic hinge } \\
\frac{P_{u}}{\mathrm{P}_{y}} \leqq 0.7 \leqq \frac{1+\beta-\lambda}{1+\beta+\lambda}\end{array}$ \\
\hline $\begin{array}{l}\text { NZNSEE } \\
\text { Vol. } 18 \\
\text { P. } 352\end{array}$ & $\begin{array}{l}\text { 4. Concentrically Braced Frames } \\
\text { 4. I Arrangement of Braces. } \\
\text { Braces shall be placed at all } \\
\text { levels in all frames assumed } \\
\text { to resist seismic action. } \\
\text { Braces shall be arranged in } \\
\text { pairs, at a particular } \\
\text { instance, there will be another } \\
\text { brace acting in compression. }\end{array}$ & $\begin{array}{l}\text { NZNSEE } \\
\text { Vol. } 18 \\
\text { P. } 352\end{array}$ & $\begin{array}{l}\text { 4. Concentrically Braced Frames } \\
\text { 4.1 Arrangement of Braces. } \\
\text { Braces shall be placed at all } \\
\text { levels in all frames assumed to } \\
\text { resist seismic action. Braces } \\
\text { shall be arranged in pairs, at } \\
\text { a particular instance, there } \\
\text { will be another brace acting } \\
\text { in compression. }\end{array}$ \\
\hline & $\begin{array}{l}\text { 4.2 Number of Mass Levels. } \\
\text { For frames with negligible } \\
\text { moment-resistance there shall } \\
\text { be no more than three mass } \\
\text { levels supported by this form } \\
\text { of construction. } \\
\text { For moment-resisting braced } \\
\text { frames designed and detailed } \\
\text { so that they would have } \\
\text { sufficient strength to resist } \\
\text { at least } 25 \text { of the seismic } \\
\text { forces specified by NzS } 4203, \\
\text { without the bracing, there } \\
\text { may be no more than five mass } \\
\text { levels supported by this form } \\
\text { of construction, provided } \\
\text { adequate special studies are } \\
\text { made to verify the seismic } \\
\text { performance. }\end{array}$ & & $\begin{array}{l}4.2 \text { As for fully ductile case with } \\
\text { appropriate modifications for } \\
\text { overstrength. }\end{array}$ \\
\hline & 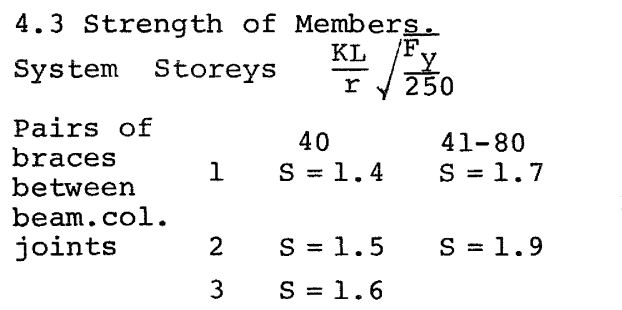 & & 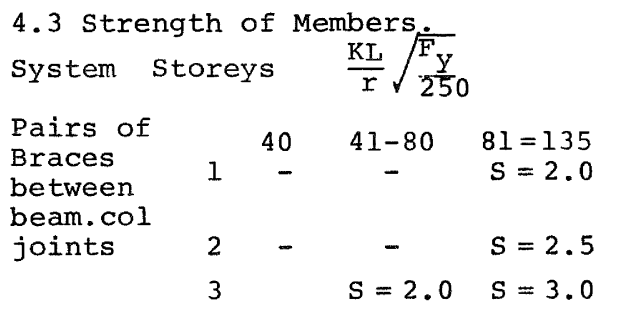 \\
\hline & $\mathrm{V}$ Bracing $\quad 1 \quad \mathrm{~S}=1.8$ & & $\begin{array}{llrc}\text { V Bracing } & 1 & \mathrm{~S}=2.5 & \mathrm{~S}=4.0 \\
& 2 \mathrm{~S}=2.0 \mathrm{~S}=3.0 & \mathrm{~S}=5.0 \\
& 3 \mathrm{~S}=2.2 \mathrm{~S}=4.0 & -\end{array}$ \\
\hline & $\begin{array}{l}\text { 4. } 4 \text { Capacity Design } \\
\text { The connections to any diagonal } \\
\text { shall be designed using an } \\
\text { factor of } 1.5 \text {, i.e. the } \\
\text { strength method design forces } \\
\text { shall be } 1.5 \text { times the speci- } \\
\text { fied area of the member times } \\
\text { the specified yield stress. } \\
\text { The members framing into any } \\
\text { diagonal shall be designed to } \\
\text { carry the above design forces. } \\
\text { For the design of columns it } \\
\text { may be assumed that only one } \\
\text { of the diagonals from any } \\
\text { three levels is yielding at } \\
\text { any one time, i.e. the force } \\
\text { from one diagonal shall be }\end{array}$ & & $\begin{array}{l}\text { 4. } 4 \text { Capacity Design } \\
\text { The connections to any diagonal } \\
\text { using an overstrength factor } \\
\text { of 1.35, i.e. the strength } \\
\text { method design forces shall be } \\
\text { 1.35 times the specified area } \\
\text { of the member times the speci- } \\
\text { fied yield stress. } \\
\text { The members framing into any } \\
\text { diagonal shall be designed to } \\
\text { carry the above design forces. } \\
\text { For the design of columns it } \\
\text { may be assumed that only one } \\
\text { of the diagonals from any three } \\
\text { levels is yielding at any one } \\
\text { time, i.e. the force from one } \\
\text { diagonal shall be calculated }\end{array}$ \\
\hline
\end{tabular}


Table 5 Continued

\begin{tabular}{|c|c|}
\hline $\begin{array}{l}\text { calculated using an over- } \\
\text { strength factor of } 1.5 \text { and the } \\
\text { other two using the dependable } \\
\text { strength reduction factor } \\
\text { (currently } 1.00 \text { ). }\end{array}$ & $\begin{array}{l}\text { using an overstrength factor of } \\
1.35 \text { and the other two using the } \\
\text { dependable strength reduction } \\
\text { factor (currently } 1.00 \text { ). }\end{array}$ \\
\hline $\begin{array}{l}4.5 \text { Detailing } \\
\text { The width to thickness ratios } \\
\text { of all members shall comply } \\
\text { with those listed for beams } \\
\text { and columns in moment } \\
\text { resistant frames. }\end{array}$ & $\begin{array}{l}4.5 \text { Detailing } \\
\text { As for fully ductile case with } \\
\text { appropriate modifications for } \\
\text { overstrength }\end{array}$ \\
\hline
\end{tabular}

The New Zealand National Society for Earthquake Engineering set up a study group to consider the state of the art in structural steel and to suggest recommendations that may be incorporated in a future steel code. The deliberations of this group have now been published [22] and form the only basis under which a limited ductile design may be undertaken in structural steel.

The main features for the design of structural steel systems of limited ductility are:

- limited ductility provisions can be applied to structures of any height or number of storeys, with capacity design provisions required for structures exceeding the height limits specified in NZS 4203, Clause 3.4.2.

- limitations are placed on breadth to thickness ratios for local buckling

- limitations are specified for lateral buckling

- maximum axial load ratios are defined in areas of possible column hinges

\subsubsection{Comparison of Design Criteria for} Ductile and Limited Ductile Systems for Buildings

A comparison of the provisions recommended by the steel study Group for the two most typical structural forms used in either the ductile or limited ductile mode is given in Table 5 .

\subsubsection{Possible Future Developments in the} Steel Design Code

The Steel study Group during its deliberations [22] highlighted the lack of seismic design information in NZS 3404 [21] and criteria required to design buildings in structural steel for limited ductility. Tentative rules were formulated and have been repeated in this paper for the more common forms of building frames that may be designed for limited ductile action.

- Moment resistant frames

- Concentrically braced frames

However while formulating criteria for design, further research needs were identified in the following fields:

Time history analysis of concentrically braced frames when designed with the proposed rules to verify that the level of seismic design forces results in satisfactory behaviour.

- Additional work to establish whether there should be a limitation on the number of stories for the various bracing forms.

- Time history analysis of moment resistant frames to verify the rules suggested for local and lateral buckling. 
Further testing and analyses of beam column joints designed to differing 'S' values.

Further testing and analysis of other structural forms such as bent bracing and steel shear walls to verify their design category.

Further testing and analysis of composite construction so that more refined design rules may be allocated to the various elements.

\subsection{TIMBER}

by A.H. Buchanan, Consulting Engineer, Christchurch.

\subsubsection{Introduction}

Timber structures have achieved a good reputation for earthquake performance over many years.

This reputation is largely based on observations of seismic behaviour of lightweight, symmetrical, and structurally redundant timber buildings with many soft connections. Damage that has occurred has often been easily repaired. In the past, timber structures have been compared favourably with brittle unreinforced masonry structures which have collapsed in moderate earthquakes.

In recent years, unreinforced masonry buildings have largely been replaced with much tougher and more ductile structures of structural steel, reinforced concrete and reinforced masonry.

Developments in timber design have produced less redundant structures with stronger connections. Both of these factors increase the possibility of timber failures (which may be sudden brittle fractures) under seismic loading, so future comparisons may not be favourable to timber. Careful design and detailing for seismic loading is essential if timber structures are to compete favourably with other materials in the long run.

Seismic design of timber structures requires an understanding of the engineering properties of timber, and the resulting behaviour of various structural systems, particularly under reversed cyclic loading.

A joint study group of the New Zealand National Society for Earthquake Engineering and the New Zealand Timber Design Society is producing useful information on the seismic behaviour and design of timber structures [23-29]. This paper is based on their work and Reference 30 .

\subsubsection{Code Requirements}

NZS 4203 [1] specifies different levels of seismic design forces for different types of structures. Forces are obtained from an acceleration spectrum, modified for type of structure and material by a factor "SM".

The value of SM depends on whether the structure is considered to be ductile, have limited ductility, or have an elastic response.

The SM values for timber structures are shown below in Table 6 .

Table 6 : SM Values in NZS 4203 [1]

\begin{tabular}{|l|ccc|}
\hline $\begin{array}{c}\text { Structural } \\
\text { Type }\end{array}$ & Ductile & $\begin{array}{c}\text { Limited } \\
\text { Ductility }\end{array}$ & $\begin{array}{c}\text { "Elastic" } \\
\text { Response }\end{array}$ \\
\hline $\begin{array}{l}\text { Shear } \\
\text { Walls }\end{array}$ & 1.0 & 1.2 & 2.4 \\
Frames & 1.2 & 1.5 & 2.4 \\
$\begin{array}{c}\text { Diagonal } \\
\text { Bracing }\end{array}$ & 1.7 & 2.0 & 2.4 \\
\hline
\end{tabular}

The value of $S M=1$ for ductile walls is consistent with other materials and systems. The value of $\mathrm{SM}=2.4$ for elastic response is considerably lower than the theoretical value of $\mathrm{SM}=4$.

The figure of 2.4 was originally chosen because of the high assumed level of damping. It has been shown subsequently that damping is low, but a SM figure in the 2.4 area can be justified on the basis of slackness built into most timber connections.

The figures shown for structures of limited ductility are suspect, because the term limited ductility is not defined, and because of uncertainty about the seismic response of many types of timber structures. These subjects are discussed later in this paper.

\subsubsection{Material Behaviour}

\section{(a) Stress-Strain Relationships}

Fig. 12 shows typical stress-strain relationships for timber in tension and in compression, both parallel to and perpendicular to the grain.

Tension failures in either direction are brittle, so these must be avoided, particularly under seismic loading. Shear failures and most bending failures are also brittle. Compression loading produces ductile behaviour. It has been suggested that many old oriental structures have performed well in earthquakes because their connections include many components stressed in compression perpendicular to the grain.

Bending behaviour depends on the ratio of tension to compression strength. If wood is stronger in tension than in compression, bending strength is governed by compression strength and bending failures tend to be ductile, not brittle. This is generally the case for small clear specimens, especially if the wood is green.

In most full size timber members (sawn timber or laminated timber in commercial grades), the material is weaker in tension than in compression, so bending failures are sudden brittle fractures. This is particularly true for the weaker members of any population. 


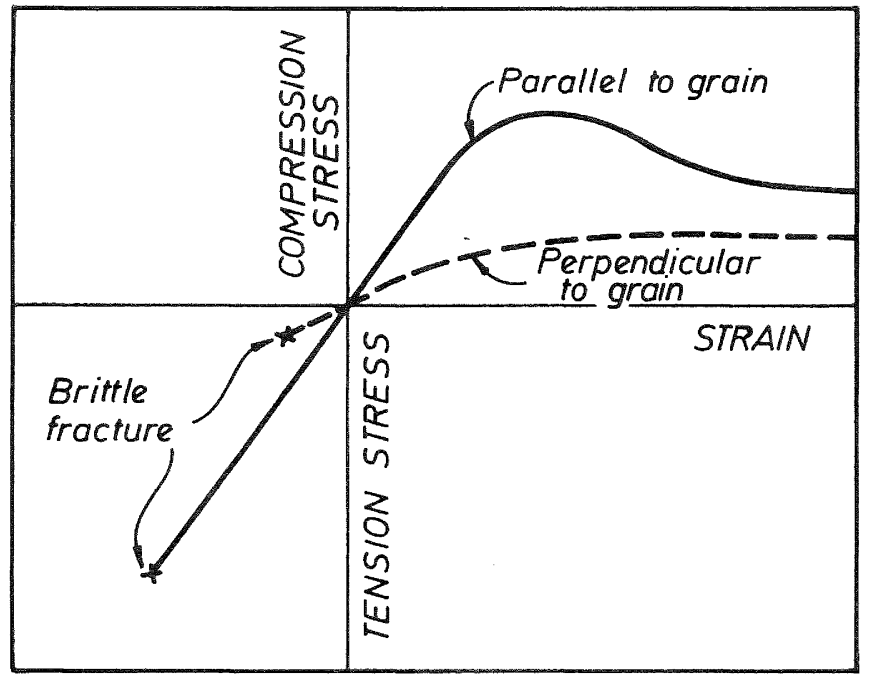

Fig. 12 - Stress-Strain Relationships for Wood [30]

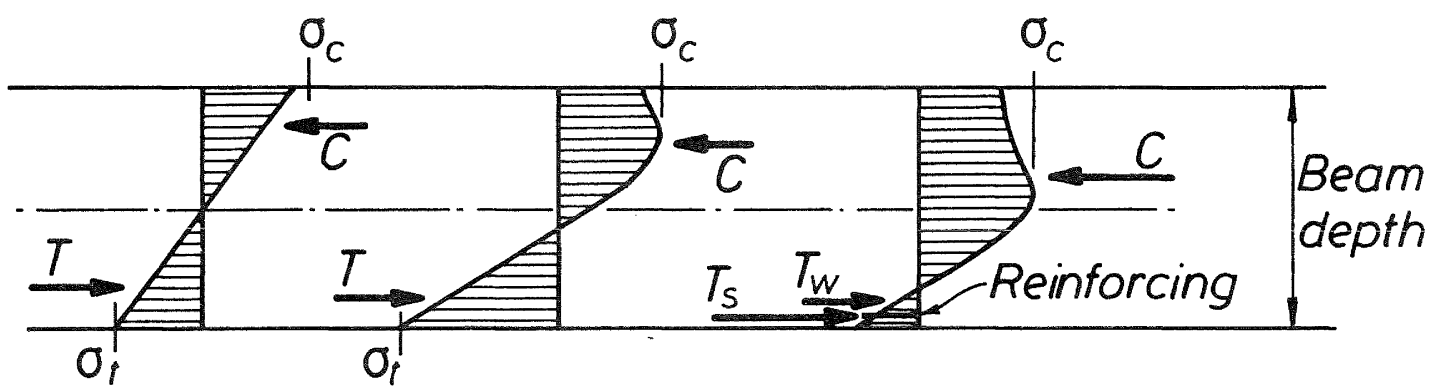

Timber Clear Wood Reinforced Timber

Fig. 13 - Bending Stresses in Timber Beams [30]

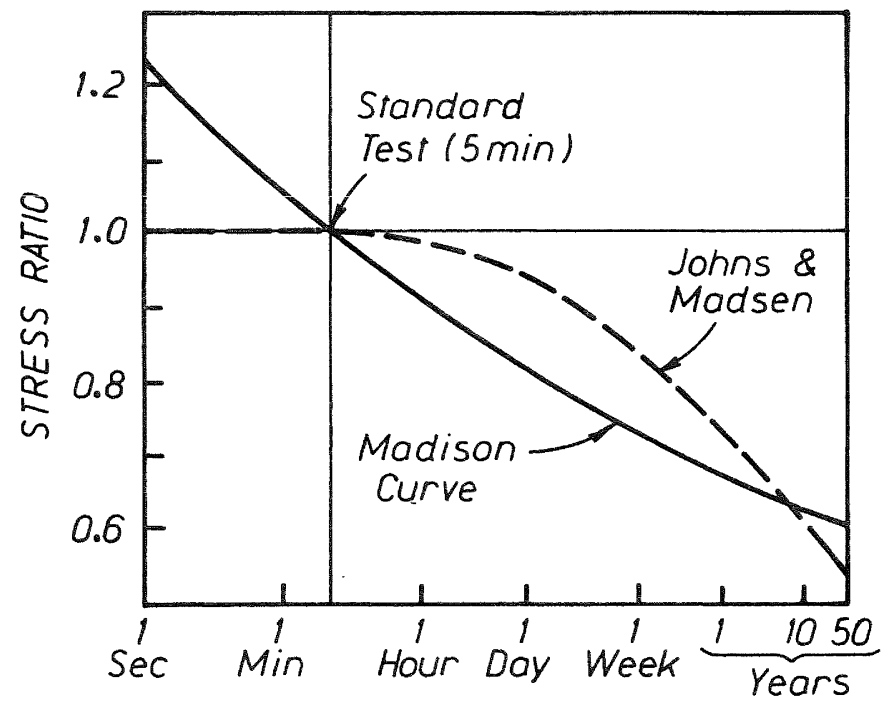


Fig. 13 shows the resulting bending stresses at maximum moment, and also illustrates how steel reinforcing can increase ductility under monotonic loading.

(b)

\section{Reversed Cyclic Loading}

The strength of timber under reversed cyclic loading, representative of earthquake loading, has not received much study.

The Wood Handbook [34] reports that the fatigue strength of small clear dry cantilever beams under 30 million cycles of reversed cyclic loading is $30 \%$ of the static strength. In another test, members with small knots and $1: 12$ slope of grain had only half the fatigue strength of clear straight-grained specimens, both specimens subjected to 2 million cycles.

Some other relevant information can be obtained from a study on the degree of damage due to proof loading [32]. This study indicated that if full size timber members are loaded in bending to $80 \%$ of their failure load, then tested in bending in the opposite direction, they will fail at only $85 \%$ of the original static failure stress.

None of these results are directly applicable to earthquake loading, but they do indicate that strength decreases under load reversals. This subject should be investigated further.

(c)

\section{Load Duration Effect}

It is well recognized that the bending strength of wood decreases under long duration loads. Recent studies relate bending strength to crack growth in tension perpendicular to the grain at local grain deviations. Duration of load tests in axial tension are in progress, but none in compression are known of.

\section{Contrary to code suggestions,} recent tests [33] show no increase in the bending strength of timber under very short duration loads. Fig. 14 compares the traditional curve for duration of load with the trend from recent studies. These findings do not support the large increase in design stresses for impact loading in Tabie 3 of the current Code (NZS 3603). Earthquake loading is correctly located in the $0.5 \mathrm{sec}$. to 6 hour range. The effect of load duration effects on most connecttion systems is unknown.

\section{Variability}

The strength of timber is very variable, and no accurate non-destructive test methods are available to predict the strength of individual pieces.

This variability must be considered for several reasons. The design stress for a single piece is based on the lower 5 th percentile strength value for the population. If several members share a load, design stresses can be increased to allow for the reduced variability resulting from load-sharing.
In a structure with no redundancies, it must be appreciated that some individual members may be weaker than the 5 th percentile design value. The variability in timber strength makes it difficult to carry out a "capacity design" procedure. For example, it can be difficult to ensure that a particular timber member is stronger than an associated ductile connection.

\section{(e) Size Effects}

Timber members exhibit a significant size effect, resulting in decreasing failure stresses as member size is increased. Size effects create problems when extrapolating from small test specimens or assemblies to large ones. The code does not adequately consider the effect of member size on strength [31].

\section{Moisture Content}

The compression strength of timber is much more affected by moisture than tension strength, showing a significant increase as moisture content drops. Hence dry timber tends to be more brittle in bending than green timber. Dimensional changes under fluctuating moisture content must also be considered, particularly perpendicular to the grain in large members. Shrinkage on drying can introduce slackness into some connections, which can have a beneficial effect by reducing the displacement demand elsewhere in the structure.

\subsubsection{Seismic Behaviour}

\section{(a) Ductility}

The term "ductility" is used often with reference to earthquake resistant design. The fundamental objective is to prevent brittle collapse, and provision of ductility is seen to be a means of achieving this. Several different meanings are associated with the term "ductility", so a brief discussion is necessary here.

In the traditional sense "ductile" and "brittle" have opposite meanings, so that a ductile structure or material is one that will not fail in a sudden brittle mode. Ductile structures have a non-linear load-deflection plot with a long yield plateau.

Using this approach, load-deflection plots under monotonic loading for typical brittle and ductile structures are shown in Fig. 15a and $\mathrm{b}$.

Many timber members behave as shown in Fig. 15c with some non-linear behaviour preceding brittle fracture. Such a member could be said to possess "limited ductility", but a better expression would be "nonlinear brittle" behaviour.

\section{Hysteresis Loops}

A ductile structure of the type shown in Fig. 15b will produce hysteresis loops under reversed cyclic loading. Depending on the material and geometry, the loops may be full loops as shown in 
Fig. 16a or pinched loops as shown in Fig. 16b. The pinched loops could be considered to indicate "limited ductility", but a better expression would be "ductile with pinched hysteresis loops".

\section{Limited Ductility}

The above discussion suggests that the term "limited ductility" must be used with care, because it may either imply non-linear brittle behaviour or alternatively ductile behaviour with pinched hysteresis loops. At low levels of displacement, both these systems will behave very similarly. The concern with the first system is that an unexpected increase in displacement demand could cause sudden collapse.

\subsubsection{Seismic Design}

The main unknown in earthquake engineering is the earthquake itself. If the nature of the earthquake were known in advance, then earthquake resistance could be provided with some certainty. Unfortunately this is never the case so approximate methods have to be used.

The actual design approach in this uncertain situation depends on whether the structure under consideration is brittle or ductile.

\section{(a) Linear Elastic Brittle Structures}

A linear elastic structure of the type shown in Fig. 15 a will respond elastically to seismic excitation. It must be designed such that the elastic response forces produced by the design earthquake are less than the probable force at which brittle failure occurs. Safety factors can be included to allow for variability in material strength, the magnitude of the earthquake and the structural response.

Elastic response deflections and accelerations can be predicted accurately from response spectra for given earthquake records.

\section{Non-linear Brittle Structures}

For a non-Iinear brittle structure such as illustrated by Fig. $15 \mathrm{c}$ the same approach applies. The non-linear behaviour means that displacements induced by the earthquake will not produce forces as large as in the linear elastic case, provided that the displacements can be tolerated. Design forces can therefore be less than indicated by an elastic response acceleration spectrum. The seismic behaviour of structures in this category depends on the degree of non-linearity in the load displacement plot, and on the displacement capacity before failure. Many structures in this category have not been adequately tested to ascertain behaviour, hence seismic design loads.

\section{Ductile Structures}

The basic seismic design approach for ductile structures is quite different.
Such structures will deform under seismic attack, generating forces corresponding to the hysteresis loops already discussed.

In most cases the displacements and resulting forces are largely independent of the shape of the hysteresis loop. Recent time-history computer studies have shown that although displacements may be slightly larger for a pinched-loop structure, the particular nature of the earthquake record itself is a much more important variable [27]. These studies show that whereas ductile structures are generally required to possess the displacement capacity of an equivalent elastic structure, certain earthquake records may impose a displacement demand two or more times larger, especially for low period structures.

Inelastic behaviour also leads to a softening of the structure, producing a longer fundamental period, which may lead to reduced response, depending on the shape of the response spectrum for the particular earthquake.

\subsubsection{NZS 4203 - Discussion of SM Values}

As a first approximation, the acceleration spectrum given in NZS 4203 [1] is a quarter of the elastic response spectrum of the design earthquake. On this basis, linear elastic structures should be designed using a value of $\mathrm{SM}=4.0$. Because of the brittle failure mode, it could be argued that this should be increased by an additional safety factor, if that is not already included in the code spectrum, or in the allowable stresses.

Conversely ductile structures can be designed for lower forces. For example an SM value of 1.0 implies a quarter of the elastic response force and a displacement ductility demand of 4 (assuming that the equal displacement principle holds).

The SM values in NZS 4203 for timber structures have been shown in Table 6 . These are discussed below with reference to various structural systems.

\section{(a) Shear Walls}

In many timber structures, lateral loads are resisted by diaphragms or shear walls, where the weakest links are the ductile nailed connections between the sheathing and the framing. Such structures can undergo many cycles of loading, producing somewhat pinched hysteresis loops [24-28]. The pinching is due to nonrecoverable crushing of wood adjacent to the nails. If properly detailed to ensure that the nails are the weakest link, shear walls are excellent ductile structural elements.

One problem with shear wall structures is the provision of suitable holdingdown devices at the ends of the wall. If the wall is not held down properly, it will rock on its foundations and nail yielding will not occur. If holding-down devices are provided, they must be strong enough in relation to the nails to ensure 


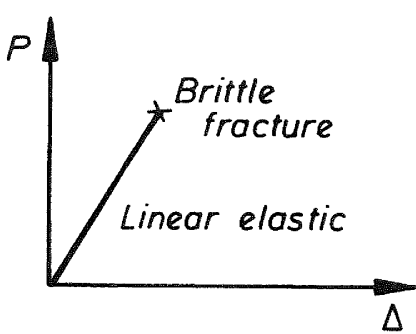

(a)

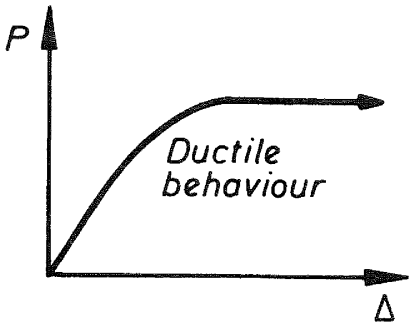

(b)

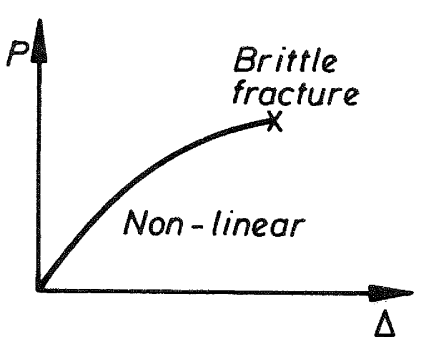

(c)

Fig. 15 - Load Deflection Plots for Monotonic Loading

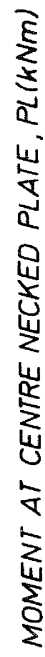

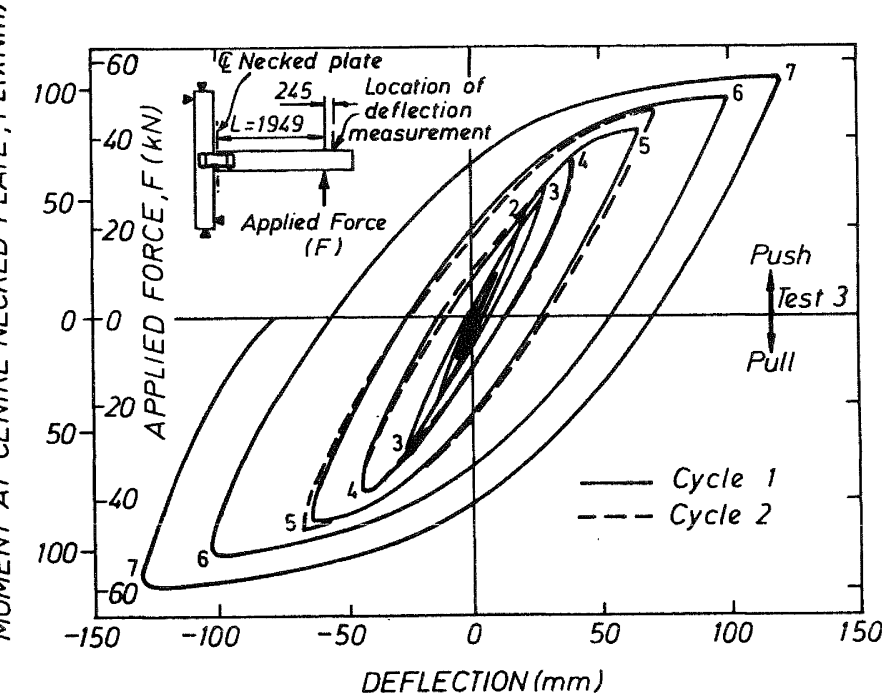

(a) Yielding steel plate joint [25]

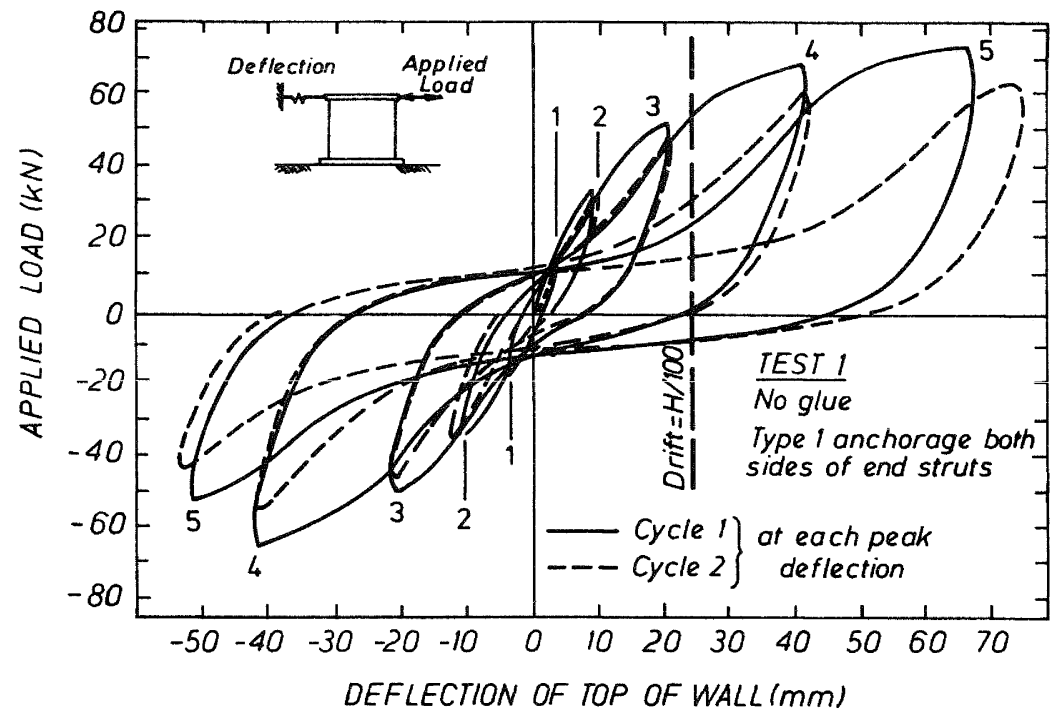

(b) Timber framed shear walls [25]

Fig. 16 - Hysteresis Loops for Cyclic Loading 
that sudden failure of the holding down devices does not occur. In this situation a capacity design procedure must be followed, recognizing that the allowable nail forces in the code are approximately half of the ultimate load capacity of the nails.

Plywood is the traditional material used on shear walls. Medium density particle and fibre boards behave similarly. Gypsum plaster board also makes a useful contribution, but suffers more damage under cyclic loading.

In view of the excellent ductile behaviour of properly detailed shear walls (or diaphragms) the code SM value of 1.0 appears reasonable. The 1.2 SM value in the code for limited ductility has no rational basis, and could lead to unsafe designs. If sufficient ductility cannot be guaranteed, but some non-linear behaviour occurs, then a value of $\mathrm{SM}=2.4$ is more appropriate.

\section{(b) Glued Connections}

Structures with rigid glued connections will generally suffer brittle failure in the glue or in the timber if loaded to failure. The load-deflection plot will generally be linear or only slightly nonlinear unless there is some slackness in the base connections. If there is no slackness or other opportunity for nonlinear behaviour, then these rigid structures should be designed for $\mathrm{SM}=4.0$, rather than the present value of $\mathrm{SM}=2.4$.

\section{Nailed Gusset Connections}

Nailed gusset connections in moment resisting timber frames can behave in a ductile manner if the nails themselves are the weakest link in the structural system. If the connections can be detailed so that "plastic hinges" can occur, then the NZS 4203 value of $S M=1.2$ appears reasonable.

The value of $\mathrm{SM}=1.5$ for connections of "limited ductility" is not appropriate in view of the discussion above. If the system is ductile, even with pinched loops, then the ductile figure of 1.2 should be used. If overload would produce a brittle failure in the timber then the elastic response figure of 2.4 should be used, assuming some non-linear behaviour.

The timber design code, NZS 3603, makes it difficult to achieve a ductile connection because it greatly underestimates the strength of nails loaded in shear. Nails through plywood have a strength 2 or more times the permissible seismic loading values, but timber (at the 5 th percentile level) has a capacity of only about 1.5 times the permissible code values.

An apparently simple design can therefore lead to the intended ductile connection being stronger than the potentially brittle members being connected. This discrepancy is even larger if steel gussett plates are used, because NZS 3603 has lower seismic design values for nails through steel than through plywood, whereas the opposite is true.

Clause 2.12 of NZS 3603 [36] has a provision requiring the relative strength of the members and the connections to be considered. Design values for nails need to be re-assessed in the light of recent testing information. The indications are that allowable code loads on nails should be increased, leading to fewer nails in each moment-resisting connection if ductile behaviour is to be ensured. A problem with this approach is that the connections become very flexible, possibly leading to serviceability problems.

However, a compromise appears possible because a small increase in joint flexibility may give the structure sufficient displacement capacity to resist a large earthquake without major damage, even though the joint would not be necessarily weaker than the timber members at ultimate load.

An alternative approach is to ensure a plastic hinge by incorporating a yielding structural steel element, in which case SM factors for structural steel could be used.

\section{Diagonal Bracing}

Diagonally braced structures are less desirable than shear walls, for example, because all the ductility is forced into a few small areas. Diagonally braced structures become very sloppy when yielding occurs only in tension.

NZS 4203 does not mention whether the relevant SM factors are for tension only yielding, or tension and compression yielding. The code value of $\mathrm{SM}=1.7$ for ductile connections may be appropriate, if in fact ductile connections can be designed. The figure of $\mathrm{SM}=2.0$ for limited ductility does not belong, once again. $\mathrm{SM}=2.4$ or 4.0 would appear to be the safer design approach for timber structures with diagonal bracing. This subject requires further research.

\section{(e) Tooth-nail Plate Structures}

Tooth-nail plate connections tend to have almost linear load-deflection behaviour to failure, whether that be by tooth withdrawal or plate failure.

Structures incorporating these connections, with no other slackness, should be designed using $\mathrm{SM}=4.0$, until further information becomes available.

\subsubsection{Possible Changes to SM Factors}

Following the above discussion many SM factors for timber structures appear too low. It appears that linear elastic structures should have $\mathrm{SM}=4$, and structures with some slackness or limited ductility should have a value about $\mathrm{SM}=2.4$. In this case Table 6 would be revised as shown in Table 7 . 
TABLE 7 : Possible Future Values of SM Factors

\begin{tabular}{|l|ccc|}
\hline $\begin{array}{c}\text { Structural } \\
\text { Type }\end{array}$ & Ductile & $\begin{array}{c}\text { Limited } \\
\text { Ductility }\end{array}$ & $\begin{array}{c}\text { Linear } \\
\text { Elastic }\end{array}$ \\
\hline $\begin{array}{l}\text { Shear } \\
\text { Walls }\end{array}$ & 1.0 & 2.4 & 4.0 \\
Frames & 1.2 & 2.4 & 4.0 \\
$\begin{array}{c}\text { Diagonal } \\
\text { Bracing }\end{array}$ & 1.7 & 2.4 & 4.0 \\
\hline
\end{tabular}

In this situation the figure of $S M=2.4$ would be used for many timber structures where some slackness or nonlinear displacement capacity exists, but where ductility cannot be guaranteed under very large displacements.

The value of these SM figures cannot be determined precisely at this stage. More information is required urgently, especially for structures incorporating diagonal bracing and toothplate connections. J. Dean, at the University of Canterbury, is carrying out an analytical study at the present time which will provide more light on these SM factors [35]. $\mathrm{He}$ is also planning an experimental study to investigate the amount of slackness, hence the SM factor, for a wide range of typical timber structures and connections.

\subsubsection{Research Needs}

The main research needs for timber structures under seismic leading are as follows:

1. The load deflection behaviour of typical timber connections needs to be investigated experimentally.

2. The results of these investigations must be used in an analytical study to determine the response of structures of various types and sizes under a wide range of earthquake time history records.

3. The strength of timber members under reversed cyclic loading, representative of earthquakes. requires investigation.

4. Current New Zealand code provisions for seismic design of timber structures need to be re-assessed, particularly with regard to structures of limited ductility. The TDS/NZNSEE Study Group is making useful progress in this area. As with all other materials, careful design and detailing of timber structures is essential if ductility is to be maintained and brittle failure prevented.

3. DESIGN OF BRIDGE SUBSTRUCTURES OF LIMITED DUCTILITY

by H.E. Chapman, Ministry of Works and Development, Wellington.

3.1 INTRODUCTION
This section discusses 'bridges of limited ductility', i.e. bridges with resistance to horizontal seismic loading exceeding that specified by codes for 'fully ductile' behaviour but less than that for elastic response. Both the current practice and likely developments are included.

Discussion of bridges of limited ductility must include all classifications of bridge type since 'Iimited ductility' bridges range from 'almost fully ductile' to 'almost elastic'. These classifications are discussed in Section 3.2.

\section{2 DESIGN METHODS \\ 3.2.1 Present Approach}

(a) Bridge Types - Satisfactory seismic design of structures depends on recognition of how they will behave, and the demands likely to be placed on various elements. Two central aspects of present design methods are the three identified types of bridge structure for seismic design purposes, and the design seismic loadings specified in the code. While the 'fully ductile' type of bridge structure is reasonably easily analysed, not all sites or bridge geometry allow suitably proportioned members to be used.

The N.Z. Concrete Design Code NZS 3101 [5] in various clauses, and commentary clauses $\mathrm{C} 3.5 .9$ and 10 in particular, subdivide bridge structures into 'ductile', 'partially ductile' and 'limited ductility' types.

\section{(i) 'Ductile'}

These form a plastic hinge mechanism with a long plateau in the force displacement relationship, sustainable over several cycles of reversed loading. A structure ductility of $\mu=6$ is usually assumed for design of structures of this type.

\section{(ii) 'Partially Ductile'}

These behave as ductile structures but with a significant upward slope in the force-displacement relationship (e.g. when in the longitudinal direction piers yield in flexure and elastomeric bearings at abutments remain elastic or energy dissipating devices are brought into action). Note that some members may behave as 'ductile" or 'limited ductile' within the overall 'partially ductile' structure.

\section{(iii) 'Limited Ductility}

1. NZS 3101 clause C3.5.10 defines these as structures where 'the configuration of structural components, the interaction of different lateral load resisting structural systems and functional requirements may result in a structure which may possess only 'limited ductility'.' Seismic design coefficients are accordingly increased to reduce the ductility demand on the structure.

2. NZS 3101 clause Cl4.4.1.3 states that bridge structures designed 'for the higher loads associated with an assumed displacement ductility factor $(\mu)$ of three 
or less may be assumed to qualify the structure for design to the requirements of Section 14' (structures of limited ductility). Note that such structures are not necessarily of limited ductility capability, but because of inherent strength in excess of that required for $\mu=6$. lesser ductility demand may be expected and hence less stringent ductility detailing may be appropriate. However, care should be taken in adopting this approach since some structures where flexibility of foundations and/or elastomeric bearings is appreciable, curvature ductility demand on the plastic hinges can be increased compared with the hinges in an equally flexible structure where all the flexibility is in the hinging member. Confinement requirements specified in NZS 3101

Section 6 are generally sufficient to ensure a displacement ductility capacity of approximately eight for the hinging member. Reduced confinement may be insufficient.

(iv) In addition, structures with sufficient strength would respond elastically, as covered by NZS 3101 Clause 3.5.11.

Force/displacement relationships for the various structural types are as shown in Fig. 17.

(b) Bridges of 'Limited Ductility'

Bridges generally have significantly different structural characteristics, and consequently different seismic behaviour, from buildings. Most of their mass is usually at one level and the pier bases are not structurally inter-linked. If plastic hinging develops it usually does so in the pier or foundation members, rather than in the superstructure, resulting in a 'column hinge mechanism' - which is normally discouraged in building frame designs but cannot be avoided in typical bridges. All of the primary seismic energy dissipation occurs within the plastic hinge zones making integrity of the hinges extremely important. Bridges are frequently constructed through poor subsoil materials, which further complicates prediction of the behaviour of the structure and its foundation elements. structural properties of bridges vary widely with tall or short piers combining with short or long spans, according to site characteristics.

Because of the above aspects, bridge design for earthquakes has to rely consider$\mathrm{ably}$ on the designer's engineering judgement in order to achieve a satisfactory earthquake resistant structure at acceptable cost. Typically 30 to $40 \%$ of a total bridge cost is in the foundation/substructure elements and, while it is desirable to design to meet the ideals of capacity design (as defined in NZ $3101,2.1$ ), doing so may lead to excessive additional foundation cost. If the proportions of the structure are such that a ductile structure can be designed to yield at the minimum code seismic coefficient (equivalent to structure ductility $=6$ ),

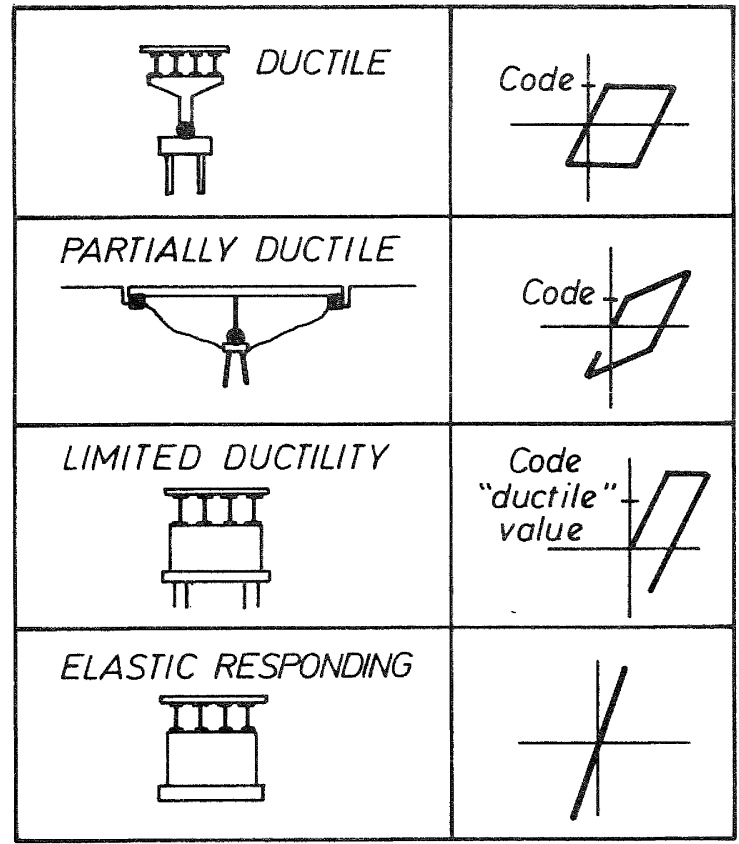

Key:-

- Plastic hinge

Elastomeric bearing

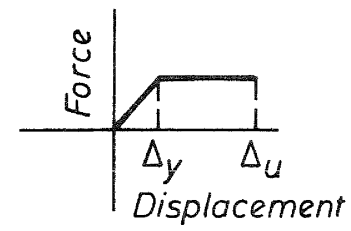

$\mu=$ Structure ductility demand

$=\frac{\Delta_{u}}{\Delta y}$

Note :-

If $\mu \leqslant 3$ NZS $3101 \mathrm{Cl}$. C14.4.1.3

qualifies structure for design to

the requirements of Section 14

(Limited Ductility) but see 2.1.1(C)2

Fig. 17 - Characteristic Force-Displacement Relationship for Bridge Types Under Seismic Loading. 
experience has shown that the cost of providing for a capacity-designed structure, with foundations remaining elastic, is usually acceptable. If however, the structure yields at larger seismic coefficients it becomes increasingly expensive to provide foundations which resist the plastic mechanism while themselves remaining elastic. Such structures are those of 'limited ductility' as in a(iii) above.

They occur under circumstances such as:

When piers are larger than structurally necessary, for architectural reasons;

When piers are short and seismic moments developing are therefore less than the yield moment of practically sized piers containing minimum main reinforcement;

When for reasons such as design in the longitudinal direction of the bridge to resist temperature induced moments, the yield moment of the pier transversely exceed the minimum necessary for seismic resistance:

When the governing design moment transversely (e.g. eccentric live loading moments on the pier) exceeds the transverse seismic moment, due to large live load eccentricity and less severe seismic zone;

When a short bridge resists transverse loading by spanning between abutments with little opportunity for flexural yielding to occur on the piers.

of these structures some are likely to be of limited ductile capacity while, because of seismic strength exceeding that for structure ductility of 6 , all will be subjected to less overall structure ductility demand than that for which the full ductile detailing is intended - however as covered in 3.2.1 (iii) 2 above, some members may still require thorough ductile detailing.

While design rules for ductile structures are referred to in NZS 3101 commentary clause $\mathrm{C} 3.5 .9$, and set out in Reference 37 , it is generally difficult to set out such rules for other structures. For this reason it is appropriate that clause 14.10 of NZS 3101 opens with "The designer shall choose a structural form with as predictable behaviour as is feasible" (14.10.1). Provision of satisfactory earthquake resistance at acceptable cost relies heavily on the choice of the best basic structural form and on the designer following the spirit as well as the letter of the code. It is accepted that damage may occur in secondary elements, preferably accessible for inspection and repair, but it is required that collapse must be avoided even under larger than design earthquake shaking.

$$
\text { Current Design Seismic Loading for }
$$
Bridges

Code seismic loading for the majority of New Zealand highway bridges is governed by the MWD Highway Bridge Design
Brief (HBDB). The current edition [38] contains 'traditional' loading curves based on the implicit assumption of ductile behaviour, with significant built-in reduction below the elastic response values. This loading is applicable to 'ductile' structures. Mention is also made of reduced ductility demand arising in structures with a yield strength exceeding code seismic loading.

Requirements such as capacity design principles are incorporated to ensure ductile behaviour is achieved and this also applies to 'structures of limited ductility'.

'Structures of limited ductility' with yield strengths sufficiently great to require uneconomical foundations are covered in the HBDB as 'non-ductile structures', for which a seismic coefficient of at least 1.5 times that for ductile structures is specified. This is equivalent to an increase in 'S factor' as used in NZS 4203 [1] and as specified in NZS 3101 clause 3.5.10.1 (a).

\subsubsection{Proposed Revisions to Design Seismic Loading for Bridges}

It is intended to change the format of the seismic loading specification in the HBDB and a draft revision dated January 1985 has been produced. This includes a format as shown in Fig. 18, which follows that developed for Reference [37]. The values shown are as suggested in Reference [39] .

Although the curves have been used for design for some time, the revised $\mathrm{HBDB}$ has not been published because of the imminent revision of the seismic loading curves in the N.Z. Code of practice for design loadings for buildings NZS 4203 [1]. The spectra produced by the Seismic Risk Subcommittee of SANZ and the committee drafting the revision will represent major progress in risk-related design spectra and seismic zoning effects throughout New zealand. It appears that the final form of curve for elastic response will be a normalised spectrum used in conjunction with 'contours' on a map of the country showing factors applicable to the spectrum to derive peak-response acceleration (see Figs. 7 and 9). This would conveniently provide for seismic zoning effects which in the present HBDB draft revision and Reference 37, are covered by three sets of curves. Whatever the final format used for defining the elastic response spectrum, it is expected that for bridge design at least, curves will provide for elastic response and for increasing values of structure ductility as in Fig. 18 . This has the advantage of clarifying for the designer the inter-relationship between structural yield strength and structure ductility demand for the 'design' eathquake, over the full range of structures from 'fully ductile' to 'elastic responding'. Note that the curves apply for a particular damping value and for a particular return period. Detailing of members for ductility is currently carried out in accordance with NZS 3101 - i.e. 
members subjected to displacement ductility

demands of more than 3 are detailed for

full ductility requirements, while those subjected to 3 or less may be detailed to the less stringent requirements of the code.

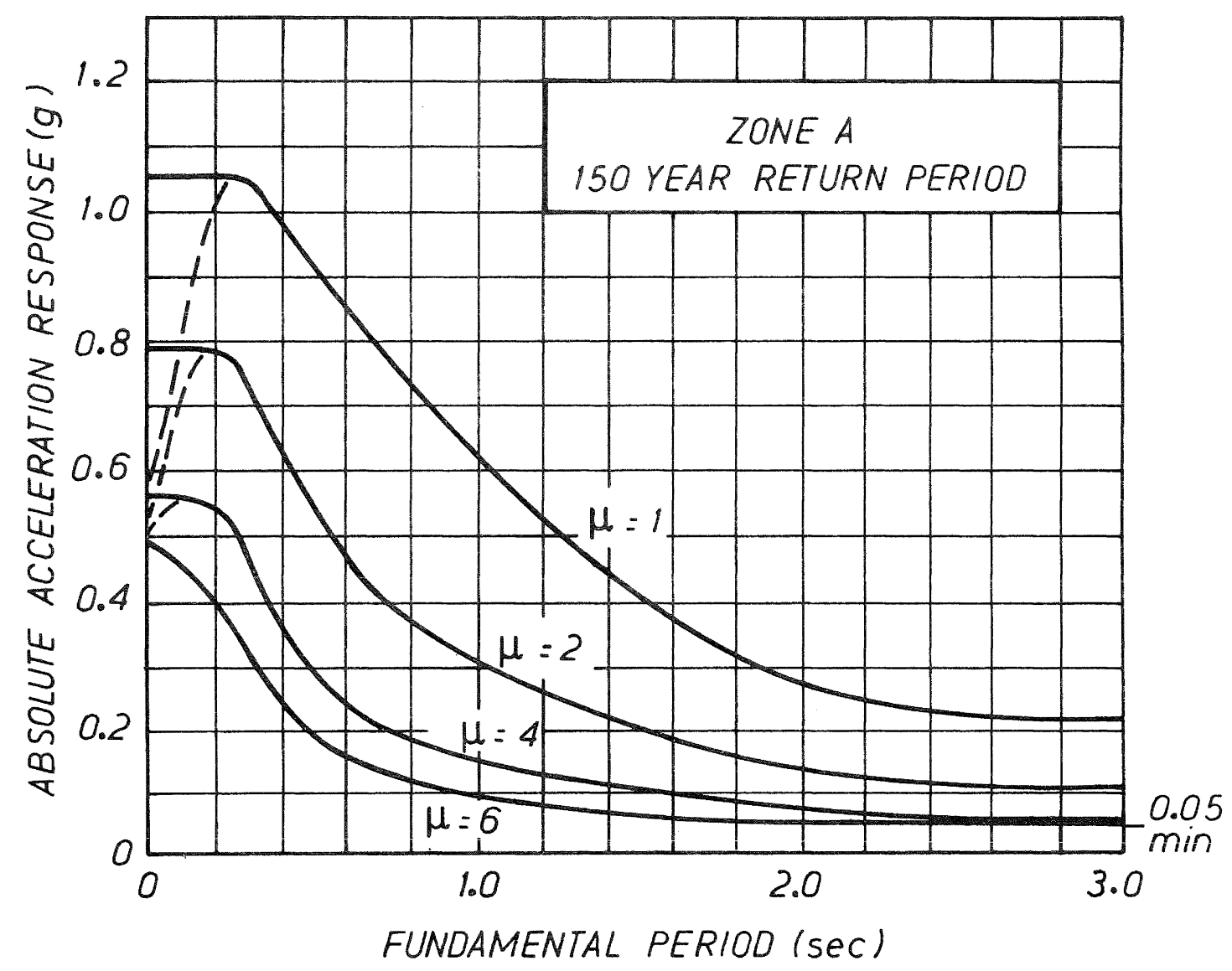

Note: Although this form of presentation will be adopted, the final values are subject to review 
For structures, other than those in the 'ductile' category, with potential plastic hinge zones in locations which are not readily accessible for inspection and repair, increased seismic coefficients are proposed in the draft revised HBDB. Curves for lesser structure ductility values would be used, as specified in Table 7 and illustrated in Fig. 19.

TABLE 7 : Proposed Maximum Values of $\mu$ for Selection of Design Seismic Loading - Refer Also to Fig. 19

Full plastic mechanism in which hinges form above ground or water level

Full plastic mechanism in which hinges form up to $2 \mathrm{~m}$ below ground, but not below water level

Full plastic mechanism in which hinges form below ground or water level, or at a level not precisely predictable

Partial plastic mechanism

Hinging in raked piles in which earthquake load induces large axial forces
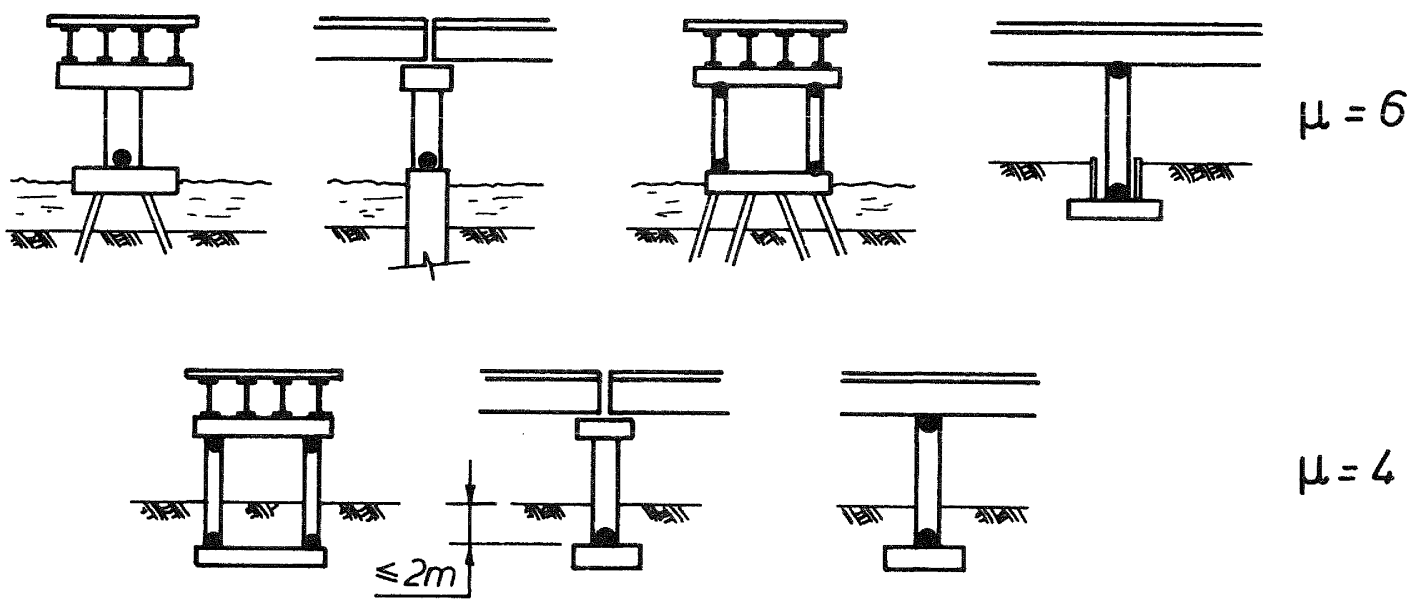

$$
\mu=4
$$
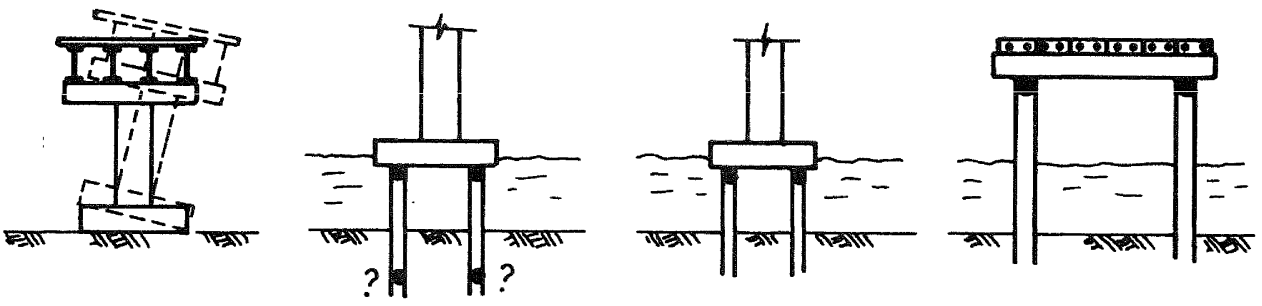

$\mu=3$
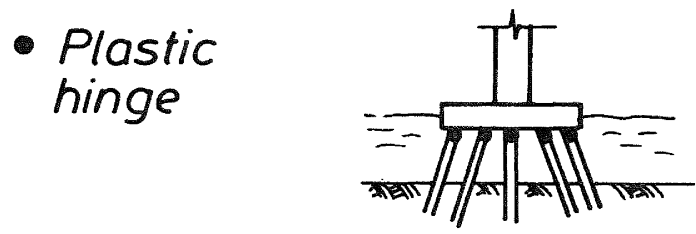
Use of increased seismic coefficients for the structures shown has the effect of increasing the threshold damage level for minor shaking and reducing the ductility demand under 'design' earthquake conditions. This is desirable for plastic hinges in inaccessible locations.

\subsubsection{Development of Design Methods for Future Use}

(a) Following the considerable research in reinforced concrete pier design during recent years [40] revised design aids are being developed by MWD to allow more reliable estimation of:

i) the curvature ductility demand likely to develop in members under the design earthquake:

ii) the confining reinforcement necessary for a chosen member size to provide for the predicted curvature ductility demand.

iii) the member curvature ductility at which splitting damage of the cover concrete would occur.

(b) The design aids will include design charts and a flow chart, which are shown in reference 41 .

While the procedure may appear complex, for most cases the amount of iteration will be limited and the design charts will simplify the process. The design procedure set out emphasises the more rigorous approach advocated for bridge structures as compared to building frames, where greater complexity would make the approach impractical. More details of the design procedures and design aids are set out in Reference $\Delta l$.

Use of these aids should remove the somewhat artificial category of 'limited ductility" structure from the bridge design field since members will be more readily tailored to match curvature ductility requirements. While it is unlikely to be a feasible procedure for building frame design, typical bridges are more readily analysed for this purpose. This procedure will not remove the situation where for reasons of economy it is necessary for a plastic hinging mechanism to be designed to develop in inaccessible locations such as piles. Policy decisions are necessary on the appropriate maximum extent to which such members should be allowed to yield under the design earthquake, thereby governing the maximum acceptable reduction factor applicable to elastic response loading. For example, should piles be more conservatively designed for the design earthquake than an above-ground pier and if so, by how much? What probability of cover concrete damage is appropriate for underground or above ground members? In some cases it may be that limitation of the frequency of damage to cover concrete will govern the pier design strength, rather than the provision of sufficient curvature ductility. This would be most likely in areas of high seismicity and in members where large curvature ductility demands are made on the hinge areas (e.g. for piers, on flexible foundations or for those carrying bearings with significant shear flexibility).

Work yet required in this area comprises completion of the design aids, experience with their use and development of governing design parameters for acceptable limit values of curvatures, for damage limitations and integrity at ultimate. These factors, combined with the prospective uniform risk design spectra, should improve the consistency of the design approach for bridge pier design compared with that currently used. Furthermore these items combined will be most suitable for estimation of the performance of existing structures designed to codes with less stringent seismic detailing requirements.

\section{3 Summary and Conclusions}

1. Code of Practice for the Design of Concrete structures NZS 3101 [5] introduced classes of structure including that of 'Iimited ductility'. The aim was to relax complexity of design and detailing where it was considered justifiable.

2. In the absence of methods by which designers can quantify available structure ductility relative to confining reinforcement quantities (a particularly complex undertaking for building structures), more general rules have been provided by NZS 3101 .

3. The relationship between required structure ductility and required member curvature ductility can often be estimated reasonably readily for bridge structures. Relevant design methods have been developed.

4. A summary of design methods for 'bridge structures of limited ductility' is complicated at this time by developments in design codes affecting both the design seismic loading and the assessment of structure capability. Methods for assessing the latter are under revision to take account of recent extensive research into reinforced concrete piers.

5. Design seismic loading curves for bridges are being revised to indicate the relationship between structure ductility demand and design seismic coefficients. The proposed revised Highway Bridge Design Brief [38] is awaiting completion of the work of the SANZ seismic risk subcommittee for incorporation of appropriate response spectra into the seismic loading curves.

6. The category 'structure of limited ductility' for bridge design purposes will be unnecessary when the proposed revisions noted in 4 and 5 above are completed.

7. The revisions in 4 and 5 above will be suitable for estimating the seismic performance of existing structures designed to codes with less stringent seismic detailing requirements than NZS 3101 . 
4. THE EVALUATION OF EXISTING STRUCTURES

by D. R. Brunsdon, Consulting Engineer, Wellington and R.B. Shephard, Ministry of Works and Development, Wellington.

\subsection{INTRODUCTION}

Despite the knowledge that many New Zealand buildings designed prior to the advent of NZS 4203 [1] possess a measure of seismic resistance, shortcomings in areas such as member detailing suggest that a significant number will be unable to respond in a ductile manner as described in section 2.1. As these buildings are also unlikely to have the required strength for a fully elastic response, it is expected that many will respond to earthquake attack in a limited ductile manner. It is anticipated that, at some time, many of these buildings will be reviewed to assess their performance.

This presentation briefly discusses the demand for evaluating existing buildings, presents New Zealand methods, comments on aspects influencing structure performance, and summarises research projects currently underway.

\subsection{THE DEMAND FOR EVALUATING EXISTING BUILDINGS}

The demand for evaluations of existing buildings can be determined from the results of various surveys carried out by the Ministry of Works and Development.

The survey of pre-1935 buildings to identify masonry earthquake risk buildings also showed that the Government has an interest in more than 400 buildings constructed in reinforced concrete or rivetted structural steel from that period. These have yet to be evaluated. Some of the reinforced concrete constructions may respond elastically, but most are expected to exhibit limited ductile characteristics.

Government has interest by ownership or lease in over 6,000 buildings of the 1936 to 1980 period. Based on design standards of the period, many buildings that are constructed in reinforced concrete or structural steel will have a limited ductile performance. A sample survey was conducted of secondary schools, post offices and telephone exchanges in a particular area. One third of the buildings are constructed in reinforced concrete or structural steel and of these one third are estimated to have less than $50 \%$ and half have less than $67 \%$ of the strength of current code requirements. In broad terms, about one third of the Government's building stock are constructed in reinforced concrete or structural steel and half of these, or about 1,000 buildings, may require assessment in detail in the future.

A nationwide survey was carried out of 47 reinforced concrete buildings that, from the date of their design and form of construction, were unlikely to meet current code requirements. A judgemental review of the details and form of buildings identified seven as possibly having an unsatisfactory seismic performance (i.e. potential of collapse failure), and three as probably meeting requirements of current codes. The remainder were considered to be uncertain in their performance. A sample of nine of the 47 buildings were selected, virtually at random in respect of structural considerations, for detailed evaluation. This sample included four buildings that the judgemental review identified with possible unsatisfactory performance. The detailed review concluded that two of these four buildings, both of which featured column shear inadequacy, required strengthening. Conclusions that the other seven (of the nine) buildings could be retained without upgrading took into account risk assessment analyses and seismicity of their specific locations. All nine buildings of the sample had strength or detail characteristics of limited ductility performance and none met current code requirements.

As particular Government buildings are considered for significant alteration or extension, extensive refurbishment, change of use to an important function, or installation of valuable contents, they are subjected to a structural review. Assessments are made to determine any strengthening requirements together with risk and aconomic analysis to establish the need to protect the asset, its function or contents. Also, as buildings are reviewed for extension of lease, their structure is assessed in order to make recommendations of lease term. With many leases coming due for renewal in Wellington City, there is currently a demand for this work.

While the Ministry of Works and Development is quite involved in evaluating buildings of the 1936 to 1975 period, it is not clear what the demand will be in the private sector. A legislative requirement similar to that resulting from the Local Government Act, or Schools Integration Act, which created a demand for strengthening unreinforced masonry buildings, would be unlikely and commercial pressures generally dictated deferred work and acceptance of risk in the meantime.

\subsection{NEW ZEALAND EVALUATION METHODS}

A research exercise undertaken in 1983 [42] reviewed available literature in New Zealand, U.S.A. and Japan describing seismic evaluation procedures for existing structures. As a result, a method based on Applied Technology Council (ATC) [43] proposals for assessing the seismic capacity of highway bridges was developed, and is reviewed in this section along with the procedures used by the Ministry of Works and Development.

\subsubsection{Brunsdon and Priestley Proposal}

The method proposed by Brunsdon and Priestley [44] for evaluating the seismic capacity of reinforced concrete frames is based on the Applied Technology Council procedures [43] with modifications to reflect requirements for loading of NZS 4203 [1] and material design to NZS 3101 [5]. The key features of this method are 
summarised briefly below, with detailed step-by-step procedures included as an appendix.

The first stage involves deriving individual member capacities and comparing with the earthquake-induced code demand forces in the form of a capacity/demand (C/D) ratio. The procedure requires the determination of $C / D$ ratios for each member, and each failure mode (e.g. flexure and shear). The magnitudes of the ratios highlight the strong and weak members, as well as the predominant mode of failure. The basic C/D ratios are calculated using demand forces corresponding to NZS 4203 elastic levels with $\mathrm{SM}=4.0$, compared with values of $\mathrm{SM}=1.6$ and 0.64 for reinforced concrete frames of limited and full ductility respectively. A resulting $C / D$ of less than one indicates that member yield in that mode will occur at less than the full code elastic level.

In. the second calculation stage, the critical elastic C/D ratios can be refined further by estimating member ductility capacity as a function of shear capacity and multiplying with the elastic $C / D$ ratio to produce a ductile $C / D$ ratio. For cases where no ductility can be expected from a member (e.g. yield in shear will occux before yield in flexure) the ductile C/D ratio equals the elastic $C / D$ ratio. The two stages of this procedure are illustrated in the flow chart of Fig. 20.

The proposed analytical model referred to above linking shear capacity with member ductility is shown in Fig. 4.2. Chapter 7 of NZS 3101 defines two levels of concrete shear contribution, $v$ referred to as non-ductile and duEtile. The ductile shear provisions, in which $\mathrm{v}_{\mathrm{C}}=0$ for beams, provide an estimate of the minimum dependable shear capacity in frames of very high ductility demand. As the ductility capacity of structures designed to the earlier codes is likely to be limited, the non-ductile shear capacities for beams and columns appear to be more relevant when determining the initial response of a frame.

The post-elastic shear behaviour model of Fig. 21 relates the subsequent decrease from the non-ductile $\left(V_{n d}\right)$ to the ductile $\left(V_{d}\right)$ shear capacity as the member ductility indreases. As shown in Fig. 21, this model can be used as a shear failure criterion by determining the level of shear demand at the development of flexural yield at both ends of an individual member. From this the member ductility is estimated, and used to generate ductile $C / D$ ratios from the elastic C/D ratios as described earlier.

The concept of the capacity/demand method of analysis is relatively straightforward, with the attraction being that in principle it can be applied to any material and structural configuration. The level of lateral load sustainable by an element may be inferred from the critical (lowest) ductile C/D ratio. This is best referred to as the nominal failure level, for in many cases the failure of a single member will not directly promote a collapse state of the building as a whole. An estimation of the level of risk posed by a particular structure can then be obtained from the relationship between the nominal failure level and the corresponding level of ground acceleration.

However, in applying this method to reinforced concrete frame structures, some problems were encountered as a consequence of the deterministic nature of the capacity design principles contained within NZS 4203 and NZS 3101 . The provisions of these codes are intended to produce the desirable energy dissipating mechanisms discussed previously in section 2.1.4 and as characterised by the 'weak-beam-strong colum' design philosophy: Existing structures not behaving according to these idealised patterns are still capable of disipating a significant amount of energy, and will not necessarily fail in a catastrophic manner. As a result, the proposed method advocates the following modifications to NSS 3101 frame design requirements (as applied to existing structures):

\section{The Dynamic Magnification Factor (w)}

The dynamic magnification factor $(\omega)$ is intended to preclude the occurrence of column hinging and hence ultimately the development of storey sway mechanisms) due to variations in the elastic column bending moment patterns. Analysis of sample frame elements [42] indicated that isolated column hinges will form and dissipate energy accordingly, with full storey mechanisms occurring only rarely. It is therefore considered unnecessarily conservative to further increase the code elastic column moments and shear forces with this factor.

\section{The Strength Reduction Factor $(\phi)$}

The strength reduction factor $(\phi)$ is employed in the design of members to account for variations in material strengths from those assumed, and to allow for general construction tolerances. However. for existing structures these aspects would appear to be more than compensated for by the enhancement of concrete strengths due to ageing. As a consequence it is proposed to use ideal strengths for shear capacities and probable strengths for flexural capacities, as discussed more fully elsewhere [44].

\subsubsection{Ministry of Works and Development Procedures}

The MWD publication "Guidelines for the Seismic Design of Public Buildings" [45] specifies the broad requirements.

To date a direct code comparison approach has been taken. For reinforced concrete buildings these codes are NZS 4203 for loadings, and NZS 3101 for design. Structural type factors (S) appropriate to the failure mechanism and reinforcement details are used to determine code loading. An analysis of the capacity and demand of the building elements results in a $R_{c}$ factor as a ratio of the element strength 


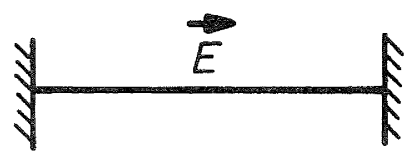

Elastic $C / D$ Ratios

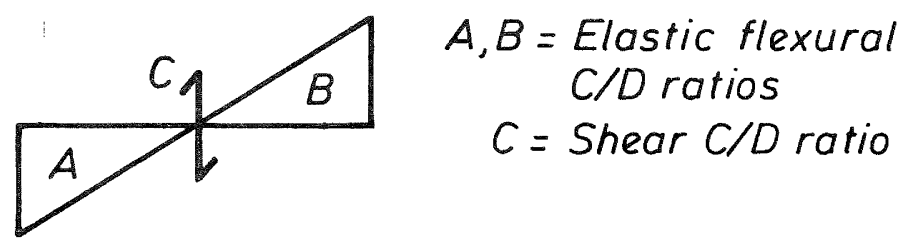

$A, B<C<1.0^{*}$

Estimate member ductilities using shear failure criterion (Fig. 21)

Ductile C/D Ratios
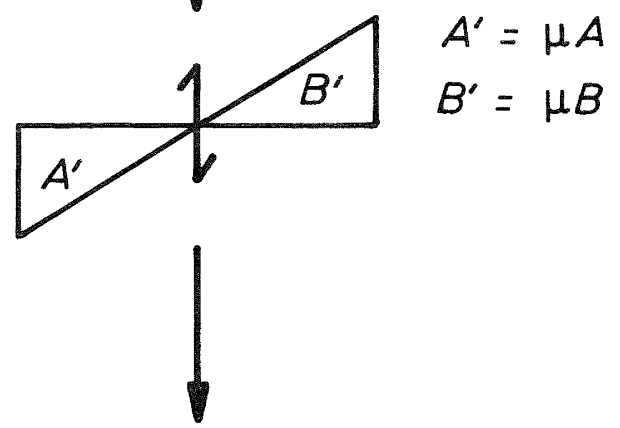

Member failure occurs at the level corresponding to the lower of $A^{\prime}$ or $B^{\prime}$

* If $A$ or $B$ is greater than $C$ then member failure is assumed to occur at the level corresponding to $C$ 


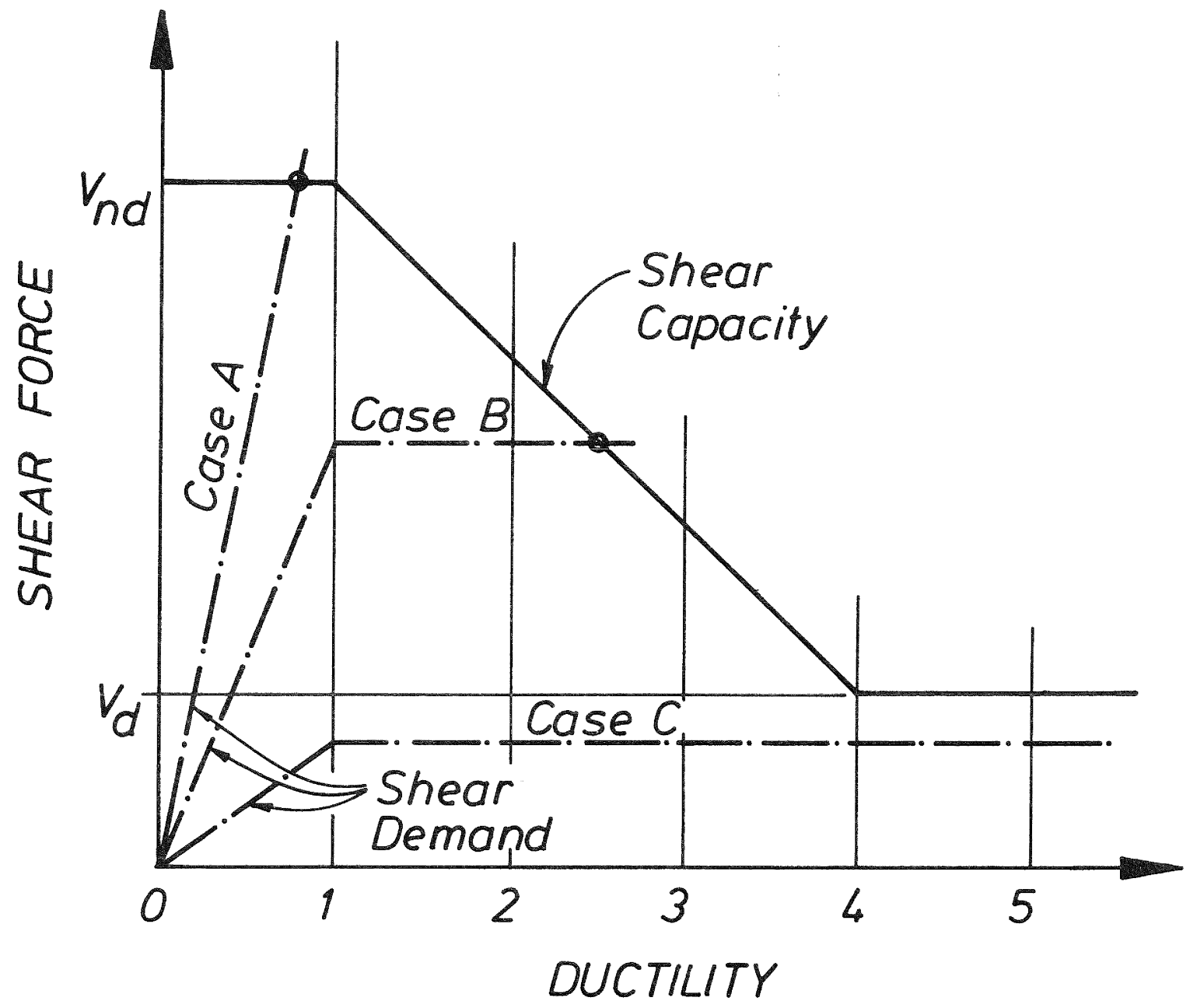

Case A:Beams or column yielding in shear Cases B \& C : Beams or columns yielding in flexure 


$$
\begin{aligned}
& R_{C}=\frac{\text { Element/Building capacity }}{\text { Loading demand to NZS } 4203} \\
& C_{d}=\text { Seismic design coefficient of NZS } 4203
\end{aligned}
$$

Ratio of $\frac{\text { Peak spectral response }}{\text { Building response at notural period }}$

$$
=\frac{p}{b}=R_{r}
$$

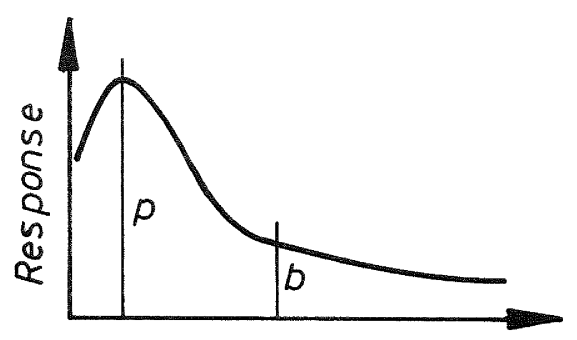

Period

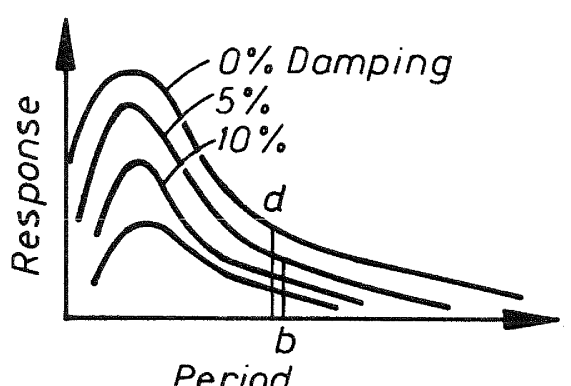

Ratio of $\frac{\text { Undamped spectral response }}{\text { Response at assumed damping }}$

$$
=\frac{d}{b}=R_{d}
$$

Assessed ductility capability (Period $>0.6 \mathrm{sec}$ )

$$
=\frac{\Delta u}{\Delta_{y}}=D
$$

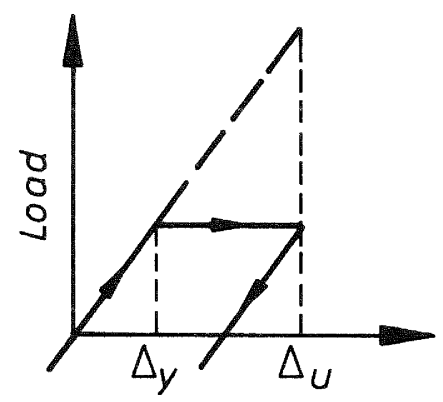

Deflection

Product $R_{C} \cdot C_{d} \cdot R_{r} \cdot R_{d} \cdot D$

= Equivalent undamped peak elastic building response and is compared with :-

\begin{tabular}{|l|c|c|c|c|}
\hline MM Intensity & $V I$ & VII & VIII & $I X$ \\
\hline $\begin{array}{l}\text { Peak Elastic } \\
\text { Response \% }\end{array}$ & 0.13 & 0.23 & 0.45 & 0.88 \\
\hline
\end{tabular}


and required loading demand. Consideration of the elements with low $R$ values is used as the basis of judgement for an overall value of $R_{C}$ for potential building collapse.

The results and recommendations to the building owner are expressed in terms of the current codes so as to promote client understanding and to allow comparison with buildings designed in accordance with those codes.

The earthquake demand, in terms of seismicity of building location, is assessed independently of NZS 4203 requirements. Using the factor of overall building $R_{c}$, seismic design coefficient, ratio of spectral peak response to building response at natural period, ratio of undamped spectral response to building response at assessed damping, and assessed ductility capability, an equivalent undamped peak elastic building response is calculated. This is then compared with the peak elastic response acceleration accorded to the range of earthquake intensities to determine that intensity of earthquake likely to cause collapse. (Refer Fig. 22). Probabilities of occurrence of that earthquake are based on the work of Smith and Berryman [46]. For consideration and aid to decision making by the building owner, a tabulation of earthquake intensity, probability over the planned building life and predicted damage is given in a report. Where strengthening work is considered, a risk and economic analysis is carried out as illustrated by McKay and Hutchison [47].

At this stage the MWD have not embraced the Brunsdon/Priestley proposals in respect of non-use of the dynamic magnification factor, the non-use of the strength reduction factor, the model for post-elastic shear behaviour or the use of probable strength for flexure. It is recognised that a lower bound of probability of capacity and an upper bound of demand probability results from this code comparison method. Comparisons of the nett results of the methods of determining capacities will be made in future studies.

In general it has not been practical nor required to undertake inelastic dynamic analysis to determine demands on elements in a particular structure.

\subsection{OTHER ASPECTS INFLUENCING STRUCTURE PERFORMANCE}

The methods outlined above can only be applied and interpreted with a measure of judgement. Consideration must also be given to the influence of other aspects on overall structure performance, and these may be summarised under two headings:

$$
\begin{aligned}
\text { Detailing - } & \text { adequacy of concrete } \\
& \text { and reinforcing confine- } \\
& \text { ment in potential } \\
& \text { plastic hinge regions. } \\
& \text { - location, length and } \\
& \text { type of main bar anchor- } \\
& \text { ages. } \\
\text { - } & \text { beam-column joint }
\end{aligned}
$$

reinforcement - general ability of joints to enable member yielding to develop.

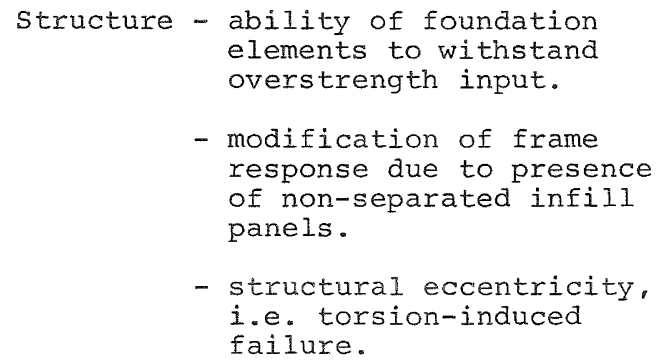
elements to withstand overstrength input.

- modification of frame response due to presence of non-separated infill panels.

- structural eccentricity. i.e. torsion-induced failure.

Although covered in NZS 4203 and NZS 3101 for new structures, the consequence of one or more of these adverse factors can be difficult to quantify, and serves to further complicate the assessment process. However, they can be used as "performance indicators" as part of the appraisal, using information gained from visual and plan inspections.

\subsection{EXAMPLES OF EVALUATIONS OF EXISTING BUILDINGS (POST 1935)}

The following examples of building evaluations illustrate the range of circumstances encountered.

A building constructed in 1936 has a 7-storey rivetted steel frame and reinforced concrete shear wall structure. The steel frame was calculated to resist a major portion of earthquake loads. Analysis identified a critical beam/column joint and local ductility demand. To establish the available ductility of rivetted construction, a full scale joint was constructed and tested. The joint performed adequately and as a consequence the building is expected to survive an MM9 earthquake without collapse. Hence the building is considered as satisfactory for long term use. The test programme cost $\$ 40,000$ in 1982 .

An eight storey building constructed with a combination of rivetted and welded structural steel frames encased in concrete, plus various reinforced concrete walls, was built in the 1940s. Considerable expenditure was proposed for re-cladding and refurbishment. The structure was evaluated and found deficient in terms of life risk and property protection. Strengthening options have considered both a structural steel eccentrically braced frame, for construction convenience and functional flexibility, and reinforced concrete shear walls. The shear wall option is proceeding to construction documentation. Inelastic time-history dynamic analysis is being used to assess ductility demands on the existing structural elements. The strengthening cost estimate is of the order of $20 \%$ of the total project.

A building designed by MWD in the mid 1960 s consists of eight storeys and features reinforced concrete shear walls transversely and a deep spandrel beam frame longitudinally. A new building has been 
constructed adjacent, and connecting walkways cut the spandrel beams. A check of the effect showed up a short column shear problem and led to a detailed evaluation. Additional shear walls are proposed in the longitudinal direction. The existing transverse shear walls do not have sufficient shear capacity according to current codes, which may result in a sliding failure mode that is not expected to lead to collapse.

A 1960 s reinforced concrete building was later extended with provision of an additional storey as originally designed. The existing shear wall and frame building was inadequate structurally and required strengthening with additional shear walls. An adjacent 1930s reinforced concrete building contained sufficient well placed walls and is expected to perform adequately on an elastic demand basis.

A powerhouse structure was constructed in 1927 in reinforced concrete walls and frames. When considered to respond elastically, some elements have only $20 \%$ of current code strength. The building geometry and yielding mechanism is not expected to lead to collapse. Moderate damage is anticipated in an MM8 earthquake, and the building is expected to survive a MM9 event without major damage at a $2 \%$ probability in the estimated 25 year life. No strengthening was recommended.

\subsection{CURRENT RESEARCH PROJECTS AND} RECOMMENDATIONS FOR FUTURE RESEARCH

The demand experienced in the MWD for assessments of the performance of existing buildings of limited ductility characteristics, and for improved design criteria for new buildings (which also has application to assessing the performance of existing buildings), has led to current research and development proposals as outlined below:

Two studies sponsored at the University of Canterbury:

- to develop design procedures for reinforced concrete walls for limited ductility

- to derive design provisions for shear and confinement for beams, columns, and beam/column joints for frames acting in a limited ductile manner.

And studies proposed in the office in conjunction with testing at Central Laboratories:

- Cyclic load testing of a limited ductility typical 1960s beam/column joint, and timber bolted joints

- cyclic load and dynamic tests of timber floor diaphragms including proposals for new construction and the typical construction found in masonry buildings.

Research requirements for existing reinforced concrete structures can be classified into analytical, theoretical and experimental categories as follows:

\section{(a) Analytical}

Development of methods and computer programmes for inelastic time-history dynamic analysis that includes the effects of axial load variation on shear capacity, yielding in shear, and progressive degrading of joints, and offers the ability to predict and follow through likely collapse mechanisms.

Further detailed elastic and inelastic investigations of a sample of taller concrete buildings (i.e. greater than 10 storeys) to verify the applicability of the proposed methods for these structures.

\section{(b) Theoretical}

Establish strength and ductility parameters for elements that have reinforcement details less than that considered necessary for fully ductile performance, e.g. shear and confinement in beams, columns and walls and lightly or unreinforced beam/ column joints in respect of shear and bond performance.

Influence on structure response due to inadequate uplift resistance, i.e. greater quantification of rocking foundation response.

\section{(c) Experimental}

Work as necessary in conjunction with the theoretical establishment of strength and ductility parameters. This may take the form of full scale tests of beams, columns, beam/column joints and extend to include typical reinforcement details with deformed and non-deformed bars.

Similar research efforts are required in order to develop detailed evaluation methods for buildings constructed in steel. timber and masonry.

\subsection{APPENDIX: PROPOSED FRAME ANALYSIS METHOD}

Step 1: Equivalent Static Force Analysis.

obtain storey shear forces.

Step 2: Overall Elastic and Torsional Analyses.

Determine the distribution of storey shear force between lateral load resisting elements.

Perform separate torsional analysis (if not included as a part of the elastic analysis) to determine whether elastic forces need to be factored up.

\section{(2) Demand Values}

Step 3: Elastic Analysis of the Frame. 
Either manually using a Muto procedure or a plane-frame computer program, apply the lateral forces indicated from step 2. The result is the individual member "code demand" forces (beam and column flexure and shear) corresponding to a full elastic response.

This can be achieved by either applying the elastic coefficient $\left[(\mathrm{SM})_{\mathrm{D}}=4.0\right]$ at step 1 , or using the ductile coefficients $[(\mathrm{SM})=$ $0.64)$ ] originaliy and factoring up the resulting member forces.

This analysis also yields the column earthquake induced axial loads ( $P_{\text {eq }}^{\circ}$ ) which are subsequently used in conjunction with the results of the gravity analysis in the determination of column flexural and shear capacities.

\section{Capacity Values}

Step 4: Gravity Load Analysis.

A conventional gravity load analysis of the frame is required to determine:

(a) the column gravity axial loads $\left(D+I_{R}\right)$;

(b) the beam gravity load moments at the column faces $(\mathrm{D}+\mathrm{L} / 3)$;

(c) the beam gravity load shear forces at a distance ' $d$ ' out from the support faces $(D+L / 3)$.

Assemble the total earthquake axial load using the load case $P_{\text {e }}=P_{D}+P_{I R}+P_{\text {eq }}$ for each

Step 5: Beam Earthquake Flexural Capacities

(a) Evaluate beam positive and negative probable flexural strengths at the column faces (extrapolate to column centrelines if demand moments are at the centrelines), including allowance for slab reinforcing as appropriate.

(b) Add/Subtract gravity load moments in order to obtain 'true" earthquake flexural capacjties for each direction of loading.

Step 6: Beam Earthquake Shear Capacities

(a) Evaluate beam ideal nonductile shear capacities adjacent to the column.

(b) Subtract gravity load shear forces in order to obtain "true" earthquake shear capacities.

Step 7: Column Flexural Capacities.
Determine the probable flexural strengths for each storey of each column.

Although Step 5 advocates the extraction of gravity load moments and shear forces from the beam capacities, it is not considered necessary to do this for the column capacities. This is because the influence of applied gravity loads has a far greater effect on the 'true' earthquake capacities for beams than columns.

Step 8: Columm Shear Capacities.

Using equations $(7-3)$ and $(7-5)$ of NZS 310I, determine the ideal non-ductile shear capacities for each storey of each column.

\section{(4) Capacity/Demand Ratios}

\section{Step 9: Elastic C/D Ratios.}

Obtain the Capacity/Demand (C/D) ratios from the corresponding capacity and demand values.

$C / D$ ratios may need to be determined for each direction of loading if either the beam flexural reinforcing or the overall frame layout is unsymmetrical. In any event, it is important that the beam and column ratios are compared for the same direction of loading, otherwise a false relationship between the two is obtained.

A C/D ratio of 0.5 , for example, indicates that yield in that mode at that location is likely to occur at one-half of the code elastic response level.

Step 10: Ductile C/D Ratios

The steps involved in determining the ductile C/D ratios are summarised in Figure 20 .

Apply the shear failure criterion of Figure 21 to members where applicable (that is, members for whom both the elastic flexural $C / D$ ratios are less than the shear $C / D$ ratio) in order to estimate the available member ductility. The elastic flexural C/D ratios are then multiplied by this ductility to obtain the ductile flexural C/D ratios.

Step 11: Joints

Comparison of the elastic C/D ratios at each node of the frame will indicate the governing member action at the joints (that is beam or column hinging). A separate joint analysis can then be carried out using the provisions of Chapter Nine of NZS 3101 for joints that are considered to be critical. 
5. REFERENCES

1) "Code of Practice for General Structural Design and Design Loadings for Buildings, NZS 4203:1984", Standards Association of New Zealand, Wellington, 1984 .

2) Draft Replacement for "Code of Practice for General Structural Design and Design Loadings for Buildings, NZS 4203:1984", Standards Association of New Zealand, Wellington, 1986.

Park, R. and Paulay, T., "Reinforced Concrete Structures", John Wiley, New York, 1975, p.769.

Park, R. and Paulay, T., "Concrete Structures", Chapter 5 of Design of Earthquake Resistant Structures, Edited by E. Rosenblueth, Pentech Press, London, 1980, pp.142-194.

"Code of Practice for the Design of Concrete Structures NZS 3101 part 1: 1982", and "Commentary on the Design of Concrete Structures, NZS 3101 Part 2: 1982", Standards Association oc New Zealand, Wellington, 1982.

White, M.P., "A Method for Calculating the Dynamic Force in a Building During an Earthquake" Bulletin of the Seismologival Society of America, Vol. 32, 1942 .

Blume, J.A., Newmark, N.M., Corning, L.H., "Design of Multi-Storey Reinforced Concrete Buildings for Earthquake Motions", Portland Dement Association, 1961.

8) Cornell, C.A. "Engineering Seismic Risk Analysis", Bulletin of the Seismological Society of America, Vol. 58, 1968.

Hutchison, D.L., Andrews, A.L. Butcher, G.W. and Kolston, D. "Draft Revision of NZS 4203:1984: Seismic Provisions", Bulletin of the New Zealand National Society for Earthquake Engineering, Vol. 19 , No. 3, September 1986, pp.158-166.

10) Katayama, T., "An Engineering Prediction Model of Acceleration Response Spectra and its Application to Seismic Hazard Mapping", Eathquake Engineering and Structural Design, John Wiley, Vol. 10, 1982.

11) Matuschka, T., Berryman, K.R. O'Leary, A.J., McVerry, G.H. Mulholland, W.M., Kinner, R.I., "New Zealand Seismic Hazard Analysis", Bulletin of the New Zealand National Society for Earthquake Engineering, Vol. 18, No. 4, December 1985, pp. $313-322$

Cook, D.R.L., "The Design and Detailing of Beam-Column Joints", Master of Engineering Report, Department of Civil Engineering, University of Canterbury, February 1984, p.284.
Soesianawati, M.T., Park, R., and Priestley, M.J.N., "Limited Ductility Design of Reinforced Concrete Columns", Research Report 86-10, Department of Civil Engineering, University of Canterbury, February 1986, p.208.

14) Zahn, F.A., Park, R., and Priestley, M.J.N., "Design of Reinforced Concrete Bridge Columns for Strength and Ductility", Research Report 86-7. Department of Civil Engineering, University of Canterbury, November 1985, p. 330 plus appendices.

"Provisional code of Practice for Masonry Design, NZS 4203P", Standards Association of New Zealand, Wellington, 1984.

Priestley, M.J.N., and Elder, D.M. "Stress-Strain Curves for Unconfined and Confined Concrete Masonry", ACI Journal, Proc. Vol. 80, No. 3, May/ June 1983, pp.192-201.

Priestley, M.J.N. and Elder, D.M. "Cyclic Loading Tests of Slender Masonry Shear Walls", Bulletin of New Zealand National Society for Earthquake Engineering, Vol. 15 No. 1, March 1982, pp.3-21.

Priestley, M.J.N., "Ductility of Unconfined Masonry Shear Walls" Bulletin of New Zealand National Society for Earthquake Engineering, Vol. 14, No. 1, March 1981, pp.12-20.

Priestley, M.J.N., "Ductility of Confined Masonry Shear Walls", Bulletin of New Zealand National Society for Earthquake Engineering, Vol.15, No. 1, March 1982, pp.22-26.

"Code of Practice for Masonry Buildings not Requiring Specific Design. NZS 4229:1985", Standards Association of New Zealand, Wellington, 1985.

"Code for Design of Steel Structures, NZS 3404:1977", Standards Association of New Zealand, Wellington, 1977.

Papers of the Study Group on the Seismic Design of Steel Structures, Bulletin of New Zealand National Society for Earthquake Engineering, Vol. 18, No.4, December 1985, pp. 323-405.

Collins, M.J., "Design Data for Nailed ailed Joints in Shear", IPENz Conference, Auckland, 1986. (Unpublished).

Dean, J.A. Stewart, W.G., and Carr, A.J., "The Seismic Behaviour of Plywood Sheathed Shear Walls", Bulletin of New Zealand National Society for Earthquake Engineering Vol. 19, No. 1, March 1986, pp.48-63.

Dowrick, D.J. "Hysteresis Loops for Timber Structures", Bulletin New Zealand National Society for Earthquake Engineering, Vol. 19, No. 2, June 1986, pp.143-152. 
26) Dowrick, D.J. and Smith, P.C. "Timber Shear Walls for Wind and Earthquake Resistance", Bulletin of New Zealand National Society for Earthquake Engineering, Vol. 19, No. 2, June 1986, pp.123-134.

Moss, P.J., Carr, A.J., and Buchanan, A.H., "Seismic Design Loads for Low Rise Buildings", IPENZ Conference, Auckland, 1986. (Unpublished).

28) Smith, P.C., Dowrick, D.J. and Dean, J.A., "Horizontal Timber Diaphragm for Wind and Earthquake Resistance", Bulletin of New Zealand National Society for Earthquake Engineering, Vol. 19, No. 2, June $1986, \mathrm{pp} .135-142$.

29) Williams, R.I., "Seismic Design of Timber Structures Study Group Report", Bulletin of New Zealand National Society for Earthquake Engineering, Vol. 19, No. 1, March 1986, pp.40-47.

30) Buchanan, A.H., "Developments in Design of Wood Structures for Earthquake Resistance", Bulletin of New Zealand National Society for Earthquake Engineering, Vol. 16, No. 2, 1983, pp.156-161.

31) Buchanan, A.H., "Effect of Member Size on the Strength of Timber". Proc. Pacific Timber Engineering Conference, Auckland, 1984, pp.462469 .

Madsen, B., "In-Grade Testing: Degree of Damage Due to Proof Loading of Lumber in Bending", Structural Research Series Report No. 17, Department of Civil Engineering, University of British Columbia, 1976.

33) Spencer, R., "Rate of Loading Effect in Bending for Douglas-Fir Lumber", Proc. First Int. Conf. on Wood Fracture, Forintek Canada Corp., Vancouver, B.C., 1979, pp.259-279.

"Wood Handbook: Wood as an Engineering Material", Agriculture Handbook No. 72 , U.S.D.A. Forest Products Lab. , 1974.

Dean, J.A., "SM Factors for Timber Structures", Unpublished Report, August 1986.

Code of Practice for Timber Design, NZS 3603:1981", Standards Association of New Zealand, Wellington, 1981.

"Papers Resulting from the Deliberations of the Society's Discussion Group on the Seismic Design of Bridges" Bulletin of New Zealand National Society for Earthquake Engineering, Vol. 13, No. 3, September 1980, pp.226-307.

"Highway Bridge Design Brief", Civil
Berrill, J.B., Priestley, M.J.N., and Peek, R., "Further Comments on Seismic Design Loads for Bridges", Bulletin of New Zealand National Society for Earthquake Engineering, Vol. 14, No. 1, March 1981, pp.3-11.

40) Priestley, M.J.N., and Park, R. "Strength and Ductility of Bridge Substructures", New Zealand Road Research Unit Bulletin No. 71, 1984.

41) Zahn, F.A., Park, R., Priestley, M.J.N. and Chapman, H.E., "Development of Design Procedures for the Flexural Strength and Ductility of Reinforced Concrete Bridge Columns", Bulletin of New Zealand National Society for Earthquake Engineering, Vo1. 19, No. 3, September 1986.

Brunsdon, D.R., "Seismic Performance Charactersistics of Buildings Constructed between 1936 and 1975", Master of Engineering Report, University of Canterbury, 1984.

43) "Seismic Retrofitting Guidelines for Highway Bridges", Report No. FHWA/ RD-83/007, US Department of Transportation and Federal Highway Administration, December 1983.

Brunsdon, D.R. and Priestley, M.J.N., Assessment of Seismic Performance Characteristics of Reinforced Concrete Buildings Constructed Between 1936 and 1975", Bulletin of the New Zealand National Society for Earthquake Engineering, Vol. 17, No. 3, September 1984 .

PW81/10/5:1985 "Guidelines for the Seismic Design of Public Buildings" Ministry of Works and Development, Wellington, October 1985.

6) Smith, W.D. and Berryman, K.R., "Revised Estimates of Earthquake Hazard in New Zealand", Bulletin of the New Zealand National Society for Earthquake Engineering, Vol. 16, No. 4, December 1983.

McKay, G.R. and Hutchison, D.L. "A Seismic Rehabilitation of Existing Buildings: An Evolving Methodology"; Proceedings of the IDEA 85 Conference, Wellington, October 1985. School of Architecture, Victoria University of Wellington and Ministry of Works and Development.

NOTE: References 23-29 are findings of the NZNSEE/NZTDS Study Group presented at the IPENZ Conference. Auckland, 1986.

\section{NOTATION}

$\mathrm{a}=$ depth of equivalent rectangular compressive stress block Division Publication CDP 701/D, September 1978, Ministry of Works and Development, Wellington, and Amendment of November 1978.
$\mathrm{A}=\mathrm{T} \ell / \mathrm{M}_{\mathrm{O}}$
$A_{g}=$ gross area of section member




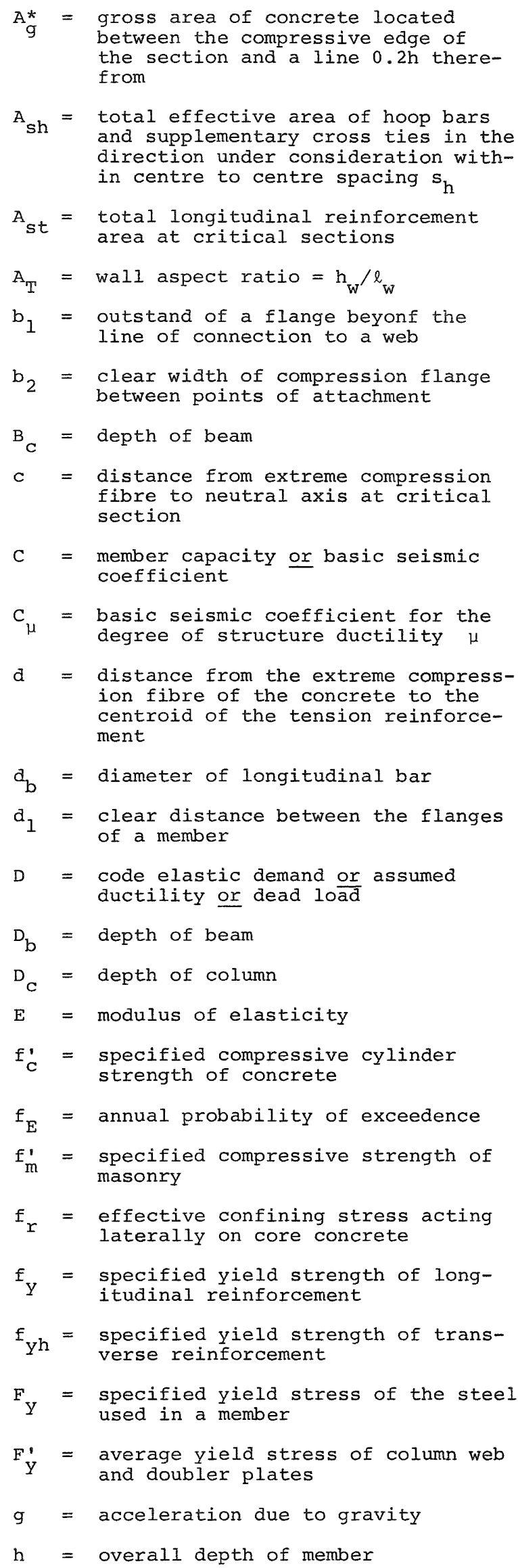

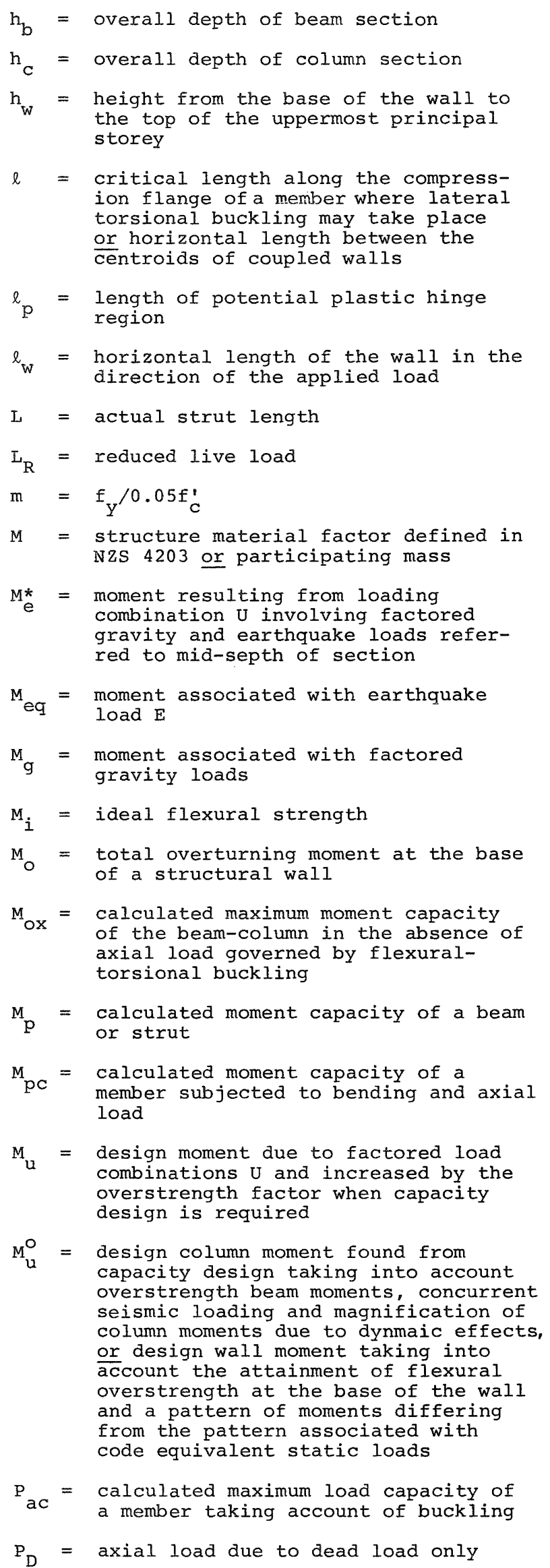


$\mathrm{P}=$ design axial load on column or wall due to loading combination involving factored gravity and earthquake loads

$\mathrm{P}_{\text {eq }}^{\circ}=$ design axial load due to earthquake actions only

$\mathrm{P}_{\mathrm{LR}}=$ design axial load due to reduced live load only

$\mathrm{P}_{u}=$ design axial load due to factored load combinations $U$ and increased by capacity design method when required

$P_{y}=$ calculated axial load capacity of a member without buckling

$r=$ radius of gyration about the same axis as the applied moment

$r_{y}=$ radius of gyration of a member about the $Y-Y$ axis

$\mathrm{R}$ = reduction factor for seismic loading or risk factor defined in NZS 4203

$\mathrm{R}_{\mathrm{C}}=$ reduction factor for confinement or ratio of element (or building) capacity to demand as obtained from NZS 4203

$\mathrm{s}=$ centre to centre spacing of sets of stirrup ties

$s_{h}=$ centre to centre spacing of sets of sets of hoops or supplementary cross ties

$\mathrm{s}=$ structural type factor defined in NZS 4203

$t=$ thickness of the web of a section

$t_{c}=$ thickness of column web

$\mathrm{T}=$ mean thickness of a flanged section or fundamenetal period of vibration $\overline{\text { of }}$ structure or axial load induced in walls by coupling beams

$\mathrm{T}_{\mathrm{C}}=$ thickness of column flange

$\mathrm{T}_{\mathrm{p}}=$ thickness of doubler plate(s)

$v_{c}=$ ideal shear stress provided by the concrete shear resisting mechanism

$v_{m}=$ shear carried by masonry shear resisting mechanisms

$\mathrm{V}=$ total horizontal seismic force in direction under consideration

$V_{d}=$ member shear capacity derived from code ductile (seismic) criteria

$V_{\text {eq }}=$ shear force associated with earthquake load $\mathrm{E}$

$V_{\text { }}=$ shear force associated with factored gravity loads

$\mathrm{V}_{i}=$ ideal shear strength
$\mathrm{V}$ = member shear capacity derived from code non-ductile (non-seismic) criteria

$V_{p}=$ calculated shear capacity of a beam or strut

$\mathrm{v}_{\mathrm{u}}=$ design shear due to factored load combinations $U$

$\mathrm{V}^{\mathrm{O}}=$ shear force found using capacity design taking into account overstrength moments, concurrent seismic loading, and magnification or moments due to dynamic effects, where appropriate

$\mathrm{W}_{\mathrm{t}}=$ gravity load on structure considered to be present during earthquake

$z=3.0-\frac{h_{w}}{\ell}$ or zone factor accounting for regional seismicity

B = ratio of end moments, each measured in the same rotational direction and chosen with the numerical larger moment in the denominator or axial load reduction factor

$\Delta_{y}=$ horizontal deflection of structure at first yield

$\Delta_{u} \quad=$ maximum horizontal deflection of structure during severe earthquake shaking

$\gamma=$ strength parameter used for confinement criteria

$\lambda=\frac{I}{\Pi r} \sqrt{\frac{F}{E}}$

$\omega=$ dynamic magnification factor

$\phi \quad=$ strength reduction factor

$\phi_{u}=$ ultimate curvature at section

$\phi_{y}=y i e l d$ curvature $=\left(\mathrm{M}_{i} / \mathrm{M}_{\mathrm{y}}\right) \phi_{y}^{\prime}$ where $\mathrm{M}_{\mathrm{Y}}^{\prime}$ and $\phi_{\mathrm{y}}^{\prime}$ are the moment ${ }^{\mathrm{y}}$ and corresponaing curvature when the longitudinal steel closest to the tension face yields or when the extreme concrete compression fibre strain reaches 0.002 , whichever occurs first

$\rho$ = longitudinal reinforcement ratio for wall $=\mathrm{A}_{\mathrm{st}} / \mathrm{A}_{\mathrm{g}}$

$\rho_{t}=$ ratio of area of longitudinal reinforcement in column, defined as ratio of area of longitudinal reinforcement to gross cross section area of column

$\rho^{*}=$ ratio of all longitudinal reinforcement within $\mathrm{A}_{\mathrm{g}}^{*}$ to area $\mathrm{A}_{\mathrm{g}}^{*}$

$\mu=$ structure or member displacement ductility factor 